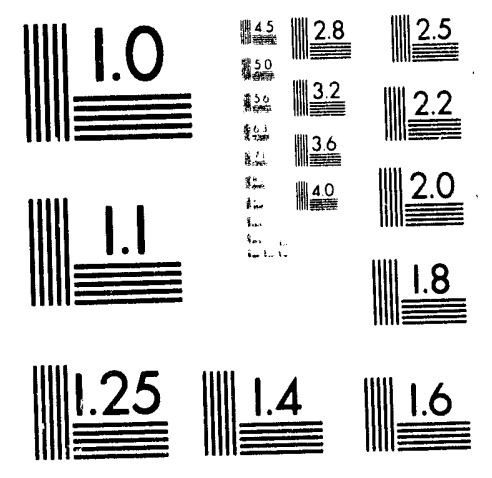




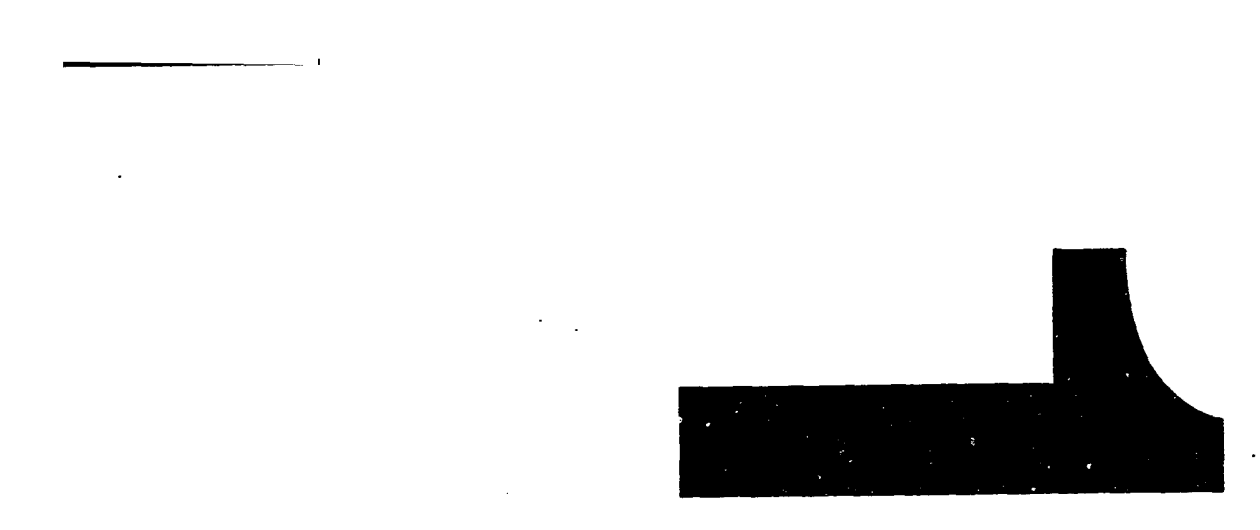




\title{
Remote Sensing for the Geobotanical and Biogeochemical Assessment of Environmental Contamination
}

\author{
by \\ James Wickham ${ }^{1}$ \\ Matthew Chesley ${ }^{2}$ \\ Juciith Lancaster ${ }^{1}$ \\ David Mouat ${ }^{1}$ \\ Desert Research Institute \\ University and Community College System of Nevada \\ Reno, Nevada
}

Publication \#45111

prepared for

DOE Nevada Field Office

U.S. Department of Energy

Las Vegas, Nevada

January 1993

DISCLAIMER

\begin{abstract}
This report was prepared as an account of work sponsored by an agency of the United States Government. Neither the United States Government nor any agency thereof, nor any of their employees, makes any warranty, express or implied, or assumes any legal liability or responsibility for the accuracy, completeness, or usefulness of any information, apparatus, product, or process disclosed, or represents that its use would not infringe privately owned rights. Reference herein to any specific commercial product, process, or service by trade name, trademark, manufacturer, or otherwise does not necessarily constitute or imply its endorsement, recommendation, or favoring by the United States Government or any agency thereof. The views and opinions of authors expressed herein do not necessarily state or reflect those of the United States Government or any agency thereof.
\end{abstract}

${ }^{1}$ Biological Sciences Center

${ }^{2}$ Water Resources Center

The work upon which this report is based was supported by the U.S. Department of Energy under Contract \#DE-AC08-90NV10845. 


\section{Acknowledgements}

We wish to thank Barbie Nauroth and Ju'.: Muhilly for their assistance with typing and processing this review, and Shirley Smith, Glen da Mahir, Linda Reichlin, and Gary Hanneman who assisted in the library searches. 


\section{Contents}

Acknowledgements

Preface 1

1.0 BACKGROUND/INTRODUCTION 2

2.0 DETECTION OF VEGETATION STRESS THROUGH HORIZONTAL SHIFTS IN THE POSITION OF THE RED EDGE 8

Laboratory Studies 9

Field and Airborne Studies $\quad 13$

Wave-Fom Analysis 16

$\begin{array}{ll}\text { Inverted Gaussian Model } & 17\end{array}$

Summary and Conclusions 18

3.0 FULL SPECTRAL MA'TCHING AND FLUORESCENCE 22

Full Spectral Matching $\quad 22$

Fluorescence $\quad 23$

Summary and Conclusions $\quad 24$

$\begin{array}{lll}4.0 & \text { RATIO TECHNIQUES } & 25\end{array}$

Forest Decline Studies $\quad 26$

Ratio Techniques Versus Wavelength Shifts $\quad 26$

Moisture Stress Detection $\quad 28$

Summary and Conclusions $\quad 29$

5.0 RESULTS OF SACRAMENTO RIVER STUDY 31

Background 31

Methodology

Complications $\quad 33$

Results $\quad 34$

Summary and Conclusions $\quad 43$

6.0 PHYSIOLOGICAL RESPONSE OF PLANTS TO STRESS

Chlorophyll/Chloroplast Development 44

$\begin{array}{ll}\text { Photosy'nthesis } & 46\end{array}$

$\begin{array}{ll}\text { Nutrient Uptake } & 49\end{array}$

Summary and Conclusions $\quad 50$

7.0 SUMMARY AND CONCLUSIONS

8.0 REFERENCES

Appendices

1. Summary of Studies Examining Plant Responses to Certain Chemical $\begin{array}{ll}\text { Compounds } & 68\end{array}$

2. Contaminants of Interest to DOE and Other Agencies 73 


\section{Figures}

Figure 1.1: The electromagnetic spectrum.

Figure 1.2: An expanded diagram of the visible and infrared regions of the EM spectrum showing atmospheric window's and band placement of commonly used remote sensing systems.

Figure 1.3: Reflectance spectra for vegetation and rock and spectral regions dominated by specific plant attributes.

Figure 2.1: Reflectance spectra (bottom) and simple difference spectrum (top).

Figure 2.2: Change in the position of the red edge inflection point (7.re) as amount of vegetation is reduced from 100 to 0 percent.

Figure 2.3: Graphic representation of IG function parameters, and comparison of $\mathrm{IG}$ modeled (dashed line) and measured (solid line) reflectance (top) and simple difference (bottom) spectra.

Figure 3.1: Difference in reflectance spectra for control (background) and stress (anomalous) balsam fir and red spruce samples.

Figure 5.1: Spectral reflectance and first derivative curves for two sites on the Sacramento River showing selection of the maximum inflection point for determining relative positions of the red edge.

Figure 5.2: $\quad$ Average spectral reflectance curves of Alnus rhombifolia (ALRH) at selected sampling sites along the Sacramento drainage, 8/13/91

Figure 5.3: $\quad$ Average spectral reflectance curves of Carex nudata (CANU) at selected sampling sites along the Sacramento drainage, 8/13/91

Figure 5.4: $\quad$ Average spectral reflectance curves of Fraxinus latifolia (FRLA) at selected sampling sites along the Sacramento drainage, 8/13/91

Figure 5.5: Average spectral reflectance curves of Peltiphyllum peltatum (PEPE) at selected sampling sites along the Sacramento drainage, 8/13/91

Figure 5.6: $\quad$ Average spectral reflectance curves of Populus trichocarpa (PO'TR) at selected sampling sites along the Sacramento drainage, 8/13/91

Figure 5.7: Average spectral reflectance curves of Salix melanopsis (SAME) at selected sampling sites along the Sacramento drainage, 8/13/91

Figure 6.1: Light-stimulated reactions of chlorophyll synthesis. 
Figure 6.2: Anatomical structure of chloroplast organelle.

Figure 6.3: Model simplification of how light energy striking a chlorophyll molecule is utilized for photosynthetic reaction:s.

Figure 6.4: $\quad \mathrm{Z}$-scheme representation of electron-transport (light) reactions of photosynthesis.

Figure 6.5: Graphic summary of Calvin-Benson (dark) reactions of photosynthesis.

Figure 7.1: Response of population density to changing environmental gradients. 


\section{Tables}

Tible 1-1.: Electromagnetic spectral regior: 3

Table 2-1: Red edge shift detection: labora:ory studies. $\quad 10$

Table 2-2: $\quad$ Red edge shift detection: field studies. $\quad 14$

Table 2-3: $\quad$ Red edge shift detection: airbome studies. 15

Table 2-4: Trends in detection of shifts in the red edge. $\quad 16$

Table 2-5: Time-series spectral data of stress and control samples. 20

Table 4-1: Ratio techniques. 25

Table 4-2: $\quad$ Ratio and similar techniques applied to forest damage detections from airborne or satellite platforms. 27

Table 5-1: Sentinel species selected for observation and analysis along the Sacramento River.

Table 5-2: Location of measured species. $\quad 32$

Table 5-3: Results of analysis conducted for the Sacramento River study. $\quad 41$

Table 6-1: Metabolic roles of essential elements. 51 


\section{PREFACE}

This document has been written to provide the Deparment of Energy (DOE) with a literature review of current remote sensing techniques that have been or can be used to examing the spectral properties of vegetation as affected by envirommental stress. As pollutants may often he the cause of vegetation stress, the ability to identify such stresses may help DOE in their efforts to locate, map, and monitor zones of contamination on DOE sites. The remote sensing studies reported in the literature have been examined with respect to their potential usefulness, and it is hoped that this resulting document will aid DOE in the development of remote sensing programs in support of Environmental Restoration and Waste Management (ERWM) activities.

To adequately cover the many aspects of deiecting vegetation stress using remote sensing techniques, a relatively lengthy document is required to discuss techniques appropriate to laboratory, field, airborne, and satellite platforms, in addition to a basic review of plumt physiology and vegetation response to stress. To provide a more useful and comprehensibie resource, this document has been split into chapters that, to some extent, can be read independently of one another.

The document consists of seven chapters: 1) Background/Introduction; 2) Detection of Red Edge Shifts in Plant Reflectance Spectra; 3) Full Spectral Matching and Fluorescence; 4) Ratio Techniques; 5) Results of the Sacramento River Study; 6) Review of Plant Physiology; and 7) Summary and Conclusions. The Introduction provides a brief overview of the unique spectral response of vegetation and how this response has been examined in vegetation stress detection studies. Chapter 2 discusses previous studies using laboratory, field, and airborne spectral data, focusing on the detection of red edge shifts to shorter or longer wavelengths. Chapter 3 presents full spectral matching techniques that have expanded on red edge shift detection studies, and introduces fluorescence. Chapter 4 presents studies that have used ratio techniques to study vegetation, and discusses the relationships between ratio and red edge shift detection techniques. Chapter 5 presents the application and results of some of these techniques in the Desert Research Insitute's (DRI) study of vegetation following the July 13, 1991, contaminant spill along the Sacramento River in northern California. Chapter 6 reviews the basic plant physiology functions related to primary production and chlorophyll development. The Summary and Conclusions tie together the results of the proceeding chapters, and highlights potential challenges and applications of future data collection and analysis efforts.

As mentioned previously, each of the chapters can be examined independently of each other. A summary and conclusions section closes each chapter to facilitate its independent treatment. The separation has been done for convenience, based on different aspects of remote sensing of vegetation stress. However, the chapters are naturally connected; therefore, we recommend that each chapter be read in turn. 


\subsection{BACKGROUND/INTRODUCTION}

Under Contract Number DE-ACO8-90NV 10845, the DOE has funded the Desert Research Institute (DRI) to examine several aspects of remote sensing, specifically with respect to how its use might help support Environmental Restoration and Waste Management (L:RWM) activities at DOE sites located throughout the country. This report represents partial fulfillment of DRI's obligations under that contract and includes a review of relevant literature asscriated with remote sensing studies and our evaluation and recommendation as to the applicability of various remote sensing techniques for DOE needs.

With respect to DOE ERWM activities, remote sensing may be broadly defined as collecting information about a target without actually being in physical contact with the object. As the common platforms for remote sensing observations are aircraft and satellites, there exists the possibility to rapidly and efficiently collect information over DOE sites that would allow for the identification and monitoring of contamination related to present and past activities. As DOE sites cover areas ranging from tens to hundreds of square miles, remote sensing may provide an effective, efficient, and economical method in support of ERWM activities.

For this review, remote sensing has been limited to methods that employ electromagnetic (EM) energy as the means of detecting and measuring target characteristics. The EM spectrum and properties there of are displayed in Figure 1.1 and Table 1-1. DRI's focus excludes electrical, magnetic, and gravity methods that are being considered by other researchers for DOE. More specifically, this review primarily encompasses passive remote sensing techniques between 0.4 and 2.5 micrometers $(\mu \mathrm{m})$. The reasons for this are straightforward: a large number of laboratory, field, airborne, and satellite instruments currently exist that have successfully demonstrated collection of data in this manner and in this region of the EM spectrum, thereby allowing the implementation and application of successful methodology with a minimum of development time.

This review discusses passive techniques between 0.4 and $2.5 \mu \mathrm{m}$, with an emphasis on vegetation and its uce as a surrogate indicator of the presence of contamination. Vegetation is in contact with both we surface and subsurface allowing it to be an integrator of conditions in both environments. Properties of vegetation, vegetation stress associated with contamination, and primarily, remote sensing techniques that allow vegetation stress to be detected are the focus of this literalure review. Where warranted, aspects of the reviewed remote sensing studies and techniques are discussed with respect to their relevancy and application to DOE concerns.

In examining the use of remote sensing techniques for application on DOE sites, methods are reviewed that primarily focus on detecting departures (or "anomalies") from normal or control reflectance spectra. Specifically, remote sensing techniques are cxamined with respect to the detection of vegetation spectral response resulting from the effects of contaminants and to use that response in the process of contamination assessment. There are several reasons for focusing on vegetation as a detection medium: plants are sessile and therefore cannot avoid environmental contaminants released into the environment; vegetation is fairly ubiquitous (even 


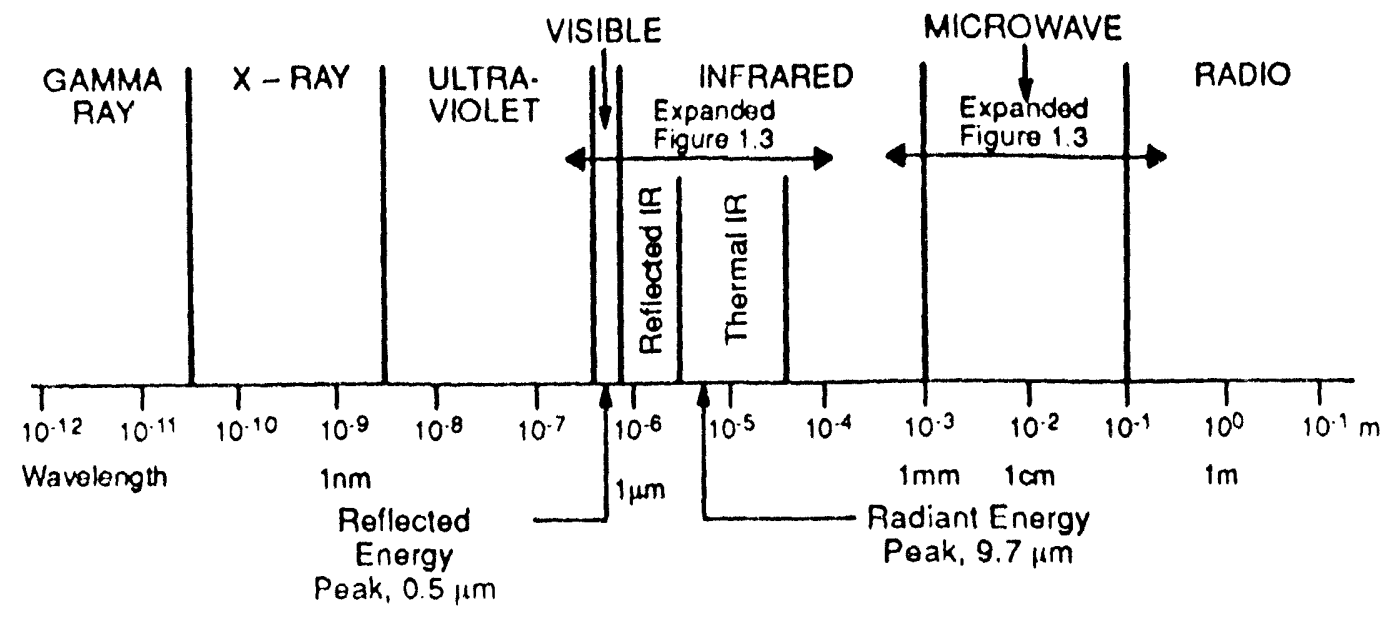

Figure 1.1: The electronagnetic spectrum (from Sabins, 1987).

Table 1-1.: Electromagnetic spectral regions (from Sabins, 1987).

\begin{tabular}{|c|c|c|}
\hline Region & Wavelength & Remarks \\
\hline Gamma ray & $<0.03 \mathrm{~nm}$ & $\begin{array}{l}\text { Incoming radiation is completcly absorbed by the upper } \\
\text { atmosphere and is not available for remole sensing. }\end{array}$ \\
\hline$X$-ray & 0.03 to $3.0 \mathrm{~nm}$ & $\begin{array}{l}\text { Completely absorted by atmosphere. Nol cmployed in } \\
\text { remote sensing. }\end{array}$ \\
\hline Uluraviolet & 0.03 to $0.4 \mu \mathrm{m}$ & $\begin{array}{l}\text { Incoming wavelengths less than } 0.3 \mu \mathrm{m} \text { are completely } \\
\text { absorbed by ozone in the upper atmosphere. }\end{array}$ \\
\hline $\begin{array}{l}\text { Photographic } \\
\text { UV band }\end{array}$ & 0.3 to $0.4 \mu \mathrm{m}$ & $\begin{array}{l}\text { Transmitted through atmosphere. Detectable with film and } \\
\text { photodetectors, but atmospheric scattering is severe. }\end{array}$ \\
\hline Visible & 0.4 to $0.7 \mu \mathrm{m}$ & $\begin{array}{l}\text { Imaged with film, photodetectors, electro-optical systems, } \\
\text { and CCDs. Includes reflected energy peak of earth at } 0.5 \\
\mu \mathrm{m} \text {. }\end{array}$ \\
\hline Infrared & 0.7 to $100 \mu \mathrm{m}$ & $\begin{array}{l}\text { Interaction with matter varies with wavelength. } \\
\text { Atmospheric transmission windows are scparated by } \\
\text { absorption bands. }\end{array}$ \\
\hline $\begin{array}{l}\text { Reflected IR } \\
\text { band }\end{array}$ & $0.7 \mathrm{to} 3.0 \mu \mathrm{m}$ & $\begin{array}{l}\text { Reflected solar radiation that contains no information } \\
\text { about thermal propertics of materials. The band from } 0.7 \\
100.9 \mu \mathrm{m} \text { is detectable with film and is called the } \\
\text { photographic IR band. }\end{array}$ \\
\hline $\begin{array}{l}\text { Thermal IR } \\
\text { band }\end{array}$ & $\begin{array}{l}3 \text { to } 5 \mu \mathrm{m} \\
81014 \mu \mathrm{m}\end{array}$ & $\begin{array}{l}\text { Principal atmospheric windows in the thermal region. } \\
\text { Images at these wavelengths are acquired by optical- } \\
\text { mechanical scanners and special vidicon systems but not } \\
\text { by film. }\end{array}$ \\
\hline Microwave & 0.1 to $30 \mathrm{~cm}$ & $\begin{array}{l}\text { Longer wavelengths can penctrate clouds, fog, and rain. } \\
\text { Imagcs may be acquired in the active or passive mode. }\end{array}$ \\
\hline Radar & 0.1 to $30 \mathrm{~cm}$ & $\begin{array}{l}\text { Active form of microwave remote sensing. Radar images } \\
\text { are acquired at various wavelength bands. }\end{array}$ \\
\hline Radio & $>30 \mathrm{~cm}$ & $\begin{array}{l}\text { Longest wavelength portion of clectromagnetic spectrum. } \\
\text { Some classificd radars with very long wavelength operate } \\
\text { in this region. }\end{array}$ \\
\hline
\end{tabular}


in arid regions); vegetation grows in both the surface and subsurface environment allowing it be in contact with pollutants in several phases; plants may be sensitive to toxic concentrations far below that needed for direct detection; through bio-accumulation of toxins, vegetation may prov ide a polential pathway for exposure or method of remediation; and finally, vegetation has a spectral profile that is unique from nearly all other earth surface materials.

The region of the EM spectrum being used by most passive remote sensing systems is shown in Figure 1.2 along with atmospheric transmittance, which dictates the placement of many instrument channels. Figure 1.3 displays a typical vegetation reflectance spectrum (changing magnitude of reflectance across a series of wavelengths) detailing the red edge and atmospheric absorption bands. Vegetation has a unique reflectance spectra from that of most other earth surface materials. The photochemical pigments (principally chlorophylls) contained within plant tissues are primarily responsible for the unusual spectral response of vegetiaton in the visible and near infrared (NIR) regions of the EM spectrum. Chlorophylls use the energy contained in the sun's radiant ilux to drive photosynthetic reactions. However, the amount of energy' in the sun's radiant flux varies across the EM spectrum and is inversely proportional to the wavelength (sce, for example, Breuer, 1975):

$$
E=\frac{c}{\lambda}
$$

where $\mathrm{c}$ is the speed of light, $\lambda$ is wavelength, and $\mathrm{E}$ is energy. Wavelengths in the infrared (IR) region ( $\approx 700 \mathrm{~nm}$ to $1 \mathrm{~mm}$ ) do not contain enough energy to drive photosynthetic reactions, and

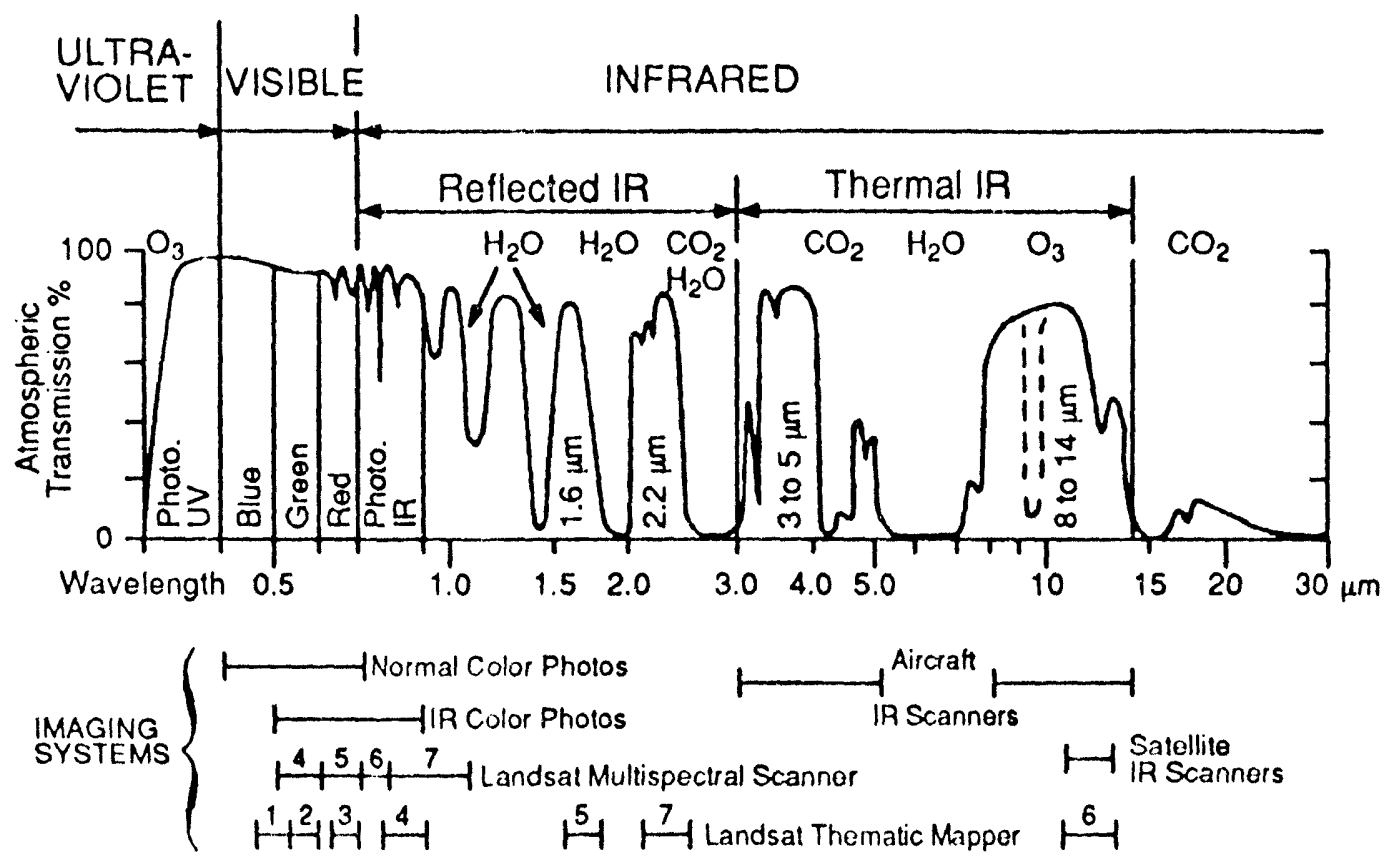

Figure 1.2: An expanded diagram of the visible and infrared regions of the EM spectrum showing atmospheric windows and band placement of commonly used remote sensing systems (from Sabins, 1987). 


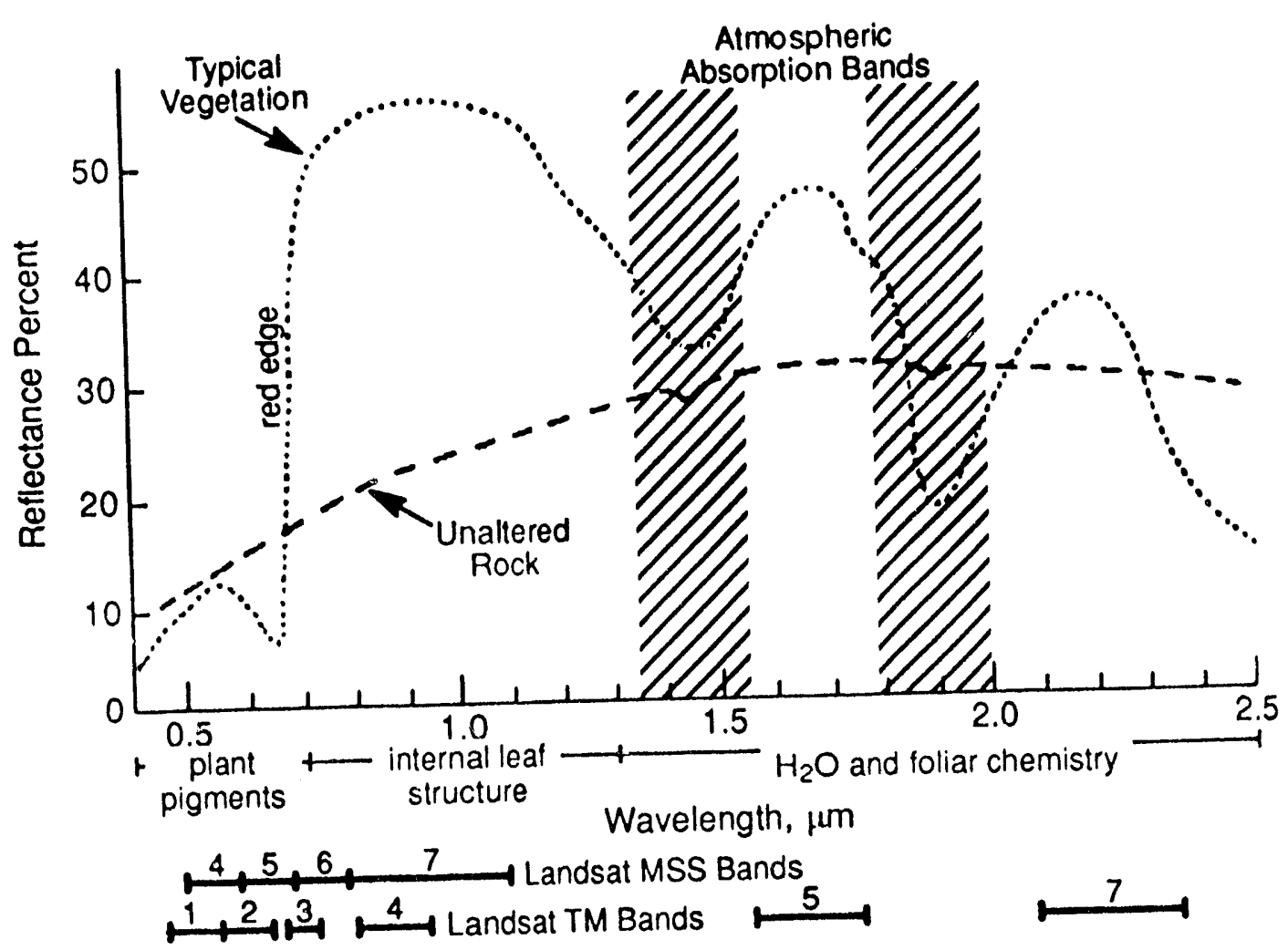

Figure 1.3: Reflectance spectra for vegetation and rock and spectral regions dominated by specific plant attributes (adapted from Sabins, 1987).

are reflected. In contrast, wavelengths in the visible region ( 400 to $700 \mathrm{~nm}$ ) of the EM spectrum contain the energy necessary to drive photosynthetic reactions, and are absorbed. Thus, the sharp increase in reflected energy from a vegetated surface at the change from the visible red to the NIR region of the EM spectrum (Figure 1.3) is the result of the energy contained in the respective regions and its utility in driving photosynthetic reactions (Salisbury and Ross, 1979). If ultraviolet (UV) radiation (less than $\approx 400 \mathrm{~nm}$ ) is considered as a third region, it is found that too much energy is contained in this region to be useful in driving photosynthetic reactions. The utility of energy in the UV, IR, and visible regions in driving photosynthetic reactions can be thought of as "too hot," "toc cold," and "just right," respertively.

The sharp increase in vegetation reflectance from the visible red to the NIR porion (at approximately $700 \mathrm{~nm}$ or $0.7 \mu \mathrm{m}$ ) of the EM spectrum is referred to as the red edge (Figure 1.3). The red edge was first reported by Gates et al. (1965), and discussed in the remote sensing literature by Knipling $(1970)^{1}$. Detecting vegetation stress with remote sensor data often employs techniques that quantify horizontal changes (change in wavelength) or vertical changes (change in magnitude of reflectance) in the red edge by comparing the red edge positions of suspected stressed vegetation to known controls (non-stressed). The position of the red edge is most often defined by the point of maximum slope or greatest change in reflectance per unit of wavelength between the regions of strong absorption and reflection centered around $700 \mathrm{~nm}$. 
Comparisons of horizontal positions have often taken advantage of the fact that a vegetation spectral profile can be easily expressed as a mathematical function (e.g., $y=F(x)$; $F(x)=a_{1}+a_{2} x+a_{3} x^{2}$, where $y=$ reflectance, $x=$ wavelength, and the $a$ 's are coefficients). The recent introduction of remote sensing instrumentation with high spectral resolution allows small changes in the position of the red edge to be observed directly in the resulting spectrum, and is more reliable than using functions to estimate red edge positions. Comparisons of vertical changes more often use ratio (or ratio based) calculations (e.g., NIR/red), and can be done with remote sensing instrumentation with a much lower spectral resolution.

Remote detection of vegetation spectral anomalies is not new. Many studies have been published reporting variations in vegetation reflectance spectra, focusing on such things as metal toxicity (Banninger, 1991; Horler et al., 1980a, 1980b; Roberts and Green, 1985; Milton et al., 1988; Lehman et al., 1990; Lichtenthaler, 1989; Lichtenthaler and Buschmann, 1987, Lichtenthaler et al., 1986; Lulla et al., 1982; Lyon, 1987; Suresh et al., 1989; Zilioli et al., 1992), plant chemical content (Card et al., 1988; Curran, 1989; Curran et al., 1991; Elvidge, 1988; Jensen et al., 1990; Marten et al., 1989; Schenk et al., 1979; Wessman et al., 1987; Norris et al., 1976; Williams, 1991), estimation of vegetation parameters and vegetation classification (Tucker et al., 1986; Quarmby et al., 1992; Williams and Nelson, 1984; Banninger, 1989; Curran et al., 1992; Huete et al., 1985), phenological development (Boyer et al., 1988; Miller et al., 1991; Schwaller and Tach, 1980; Schwaller et al., 1981; Labovitz et al., 1985; Williams et al., 1983), moisture/temperature stress (Carlson et al., 1971; Cure et al., 1989; Danson et al., 1992; Holben et al., 1983; Jackson et al., 1980; Kleman and Fagerlund, 1987; Pierce et al., 1990; Riggs and Running, 1991; Gulaid, 1986; Steinmetz et al., 1990), and airborne pollution and pest infestation (Khorram et al., 1989; Rosema et al., 1992; Rock et al., 1986). The "newness" of this effort is brought about by recent developments in instrumentation that allow the detection of much smaller variations in vegetation reflectance spectra from ground and airborne platforms at local and regional scales. Furthermore, this effort involves multi-disciplinary investigations combining knowledge of sensor development (laboratory, field, airborne, and satellite instruments), spectral mixing, vegetation characteristics, contaminant relationships, and computer programing. In addition, research is needed to define species-specific, normal or unstressed spectral reflectance properties and contaminant related affects to observe and detect variations due to contamination. The identification of these parameters is the stepping stone to effectively and efficiently characterize contamination on a regional scale.

\footnotetext{
'Reviews by Knipling (1970), and others, have complicated somewhat the significance of the vegetation spectral profile by attributing high reflectivity in the near infrared $(\approx 700$ to $1,300 \mathrm{~nm})$ to leaf anatomical structure. Whilc this is technically correct, it obscures the fact that this wavelength region of light does not contain sufficient energy to excite chlorophyll pigments, and would therefore be reflected or transmitted, since these are the only other outcomes possible. The article by Knipling is still widely cited in the literature, and is often accompanicd by a typical vegetation reflectance spectrum that attributes its unique spectrum to chlorophyll pigment absorption, leaf anatomy, and water absorption among the three regions $\approx 400$ to $700 \mathrm{~nm}, \approx 700$ to 1,300 $\mathrm{nm}$, and $\approx 1,300102,400 \mathrm{~nm}$, respectively.
} 
While there have been an extensive number of vegetation contaminant exposure studies as referenced in Appendix 1, most were not concerned with changes in spectral properties and many do not include contaminants or vegetation species of concern to DOE. A list of pollutants of concern to DOE and other agencies is given in Appendix 2. Generally, the contaminants found on DOE sites can be placed into four groups (volatile organic compounds, heavy metals, radioactive compounds, and inorganic compounds). Of these four, metal toxicity has received the most attention in the remote sensing literature, largely due to its relationship to economic mineral deposits. Therefore, a significant need exists to define the spectral affects of previously untested contaminants on numerous vegetation species to efficiently apply remote sensing techniques at DOE facilities. Experiments must also be designed for optimal application of remote sensing methods, since the detection of stress in individual leaves does not guarantee that the same stress will be detectable or mappable in airborne or satellite remote sensing applications. Nor does success in humid environments guarantee successful implementation in arid environments. It will be necessary to define these unknown characteristics with careful consideration of future applications for maximum benefit to DOE and other agencies concerned with the detection, monitoring, and remediation of contaminated areas. 


\subsection{DETECTION OF VEGETATION STRESS THROUGH HORIZONTAL SHIFTS IN THE POSITION OF THE RED EDGE}

As previously shown in Figure 1.3, properties of vegetation reflectance spectra include the atsorption wells in the blue $(400$ to $500 \mathrm{~nm})$ and red $(600$ to $700 \mathrm{~nm})$ wavelength regions, the reflectance hump in the green region, and the area of rapid change in reflectance between the red and near infrared (NIR) regions $(\approx 700 \mathrm{~nm}$ ) known as the red edge. A majority of research has focused on detecting changes in the red edge, as it is one of the more significant features in vegetation reflectance spectra.

Detection of horizontal shifts in the position of the red edge can be calculated by subtracting the percent radiance $(\% R)$ at wavelength $n\left(\lambda_{n}\right)$ from $\% R$ at $\lambda_{n-1}$. This series of simple s.:htractions is calculated across the entire series of wavelengths that constitute the red edge fortion of the electromagnetic (EM) spectrum, approximately $67010760 \mathrm{~nm}$. Many investigators compute the subtractions across the EM spectrum from $400101,000 \mathrm{~nm}$, or snme subset of this range (Rock et al., 1988; Curtiss and Ustin, 1989; Karr and Mouat, 1990). This series of calculations simply creates the first derivative of the measured spectrum and is termed the simple difference spectra (SDS). Simple difference or first derivative spectra is discussed thoroughly by Boochs et al. (1990) and is summarized below. The Boochs et al. (1990) red edge equation is defined as:

$$
d r(i)=r(i)-r(i-1)
$$

where $r(i)$ is the radiance at wavelerigth (i). The authors used radiance values for 90 wavebands 2 from 623 to $802 \mathrm{~nm}$. The graphical depiction of the original spectral profile (bottom) and simple difference spectra (top) is reproduced in Figure 2.1.

The actual position of the red edge is most often defined as the wavelength of maximum change (slope) in radiance, and is equivalent to the maximum inflection point (MIP) of the first derivative spectra. Figure 2.1 displays the MIP labeled $d r_{\max }$ and the corresponding wavelength position of the red edge $\left(\lambda_{\text {Tc }}\right)$. An SDS typically has a parabolic shape between 670 and $760 \mathrm{~nm}$, with the maximum difference in radiance defining the peak of the parabola where the slope begins to decrease. In the example illustrated by Boochs et al. (1990), the red edge inflection point occurs at about $730 \mathrm{~nm}$.

It should be noted that variations of the red edge equation are also used. For example, Ambrosia et al. (1991) defined their red edge equation including the wavelength difference as a divisor as:

$$
R_{n}-R_{(n-1)} / \lambda_{n}-\lambda_{(n-1)}
$$

wher $R$ is the percent radiance for waveband $n$ and $\lambda$ is the wavelength midpoint for that wavivand. This allows for limitations in the instrument to be accounted for.

${ }^{2}$ Waveband is a term that is used to describe the spectral resolution of a sensor when that resolution spans more than 1 unit (c.g., nanometers) of wavelength. In the case of Boochs ct al. (1990), the wavebands spanned $2 \mathrm{~nm}$ (nanometers) of wavelength. 


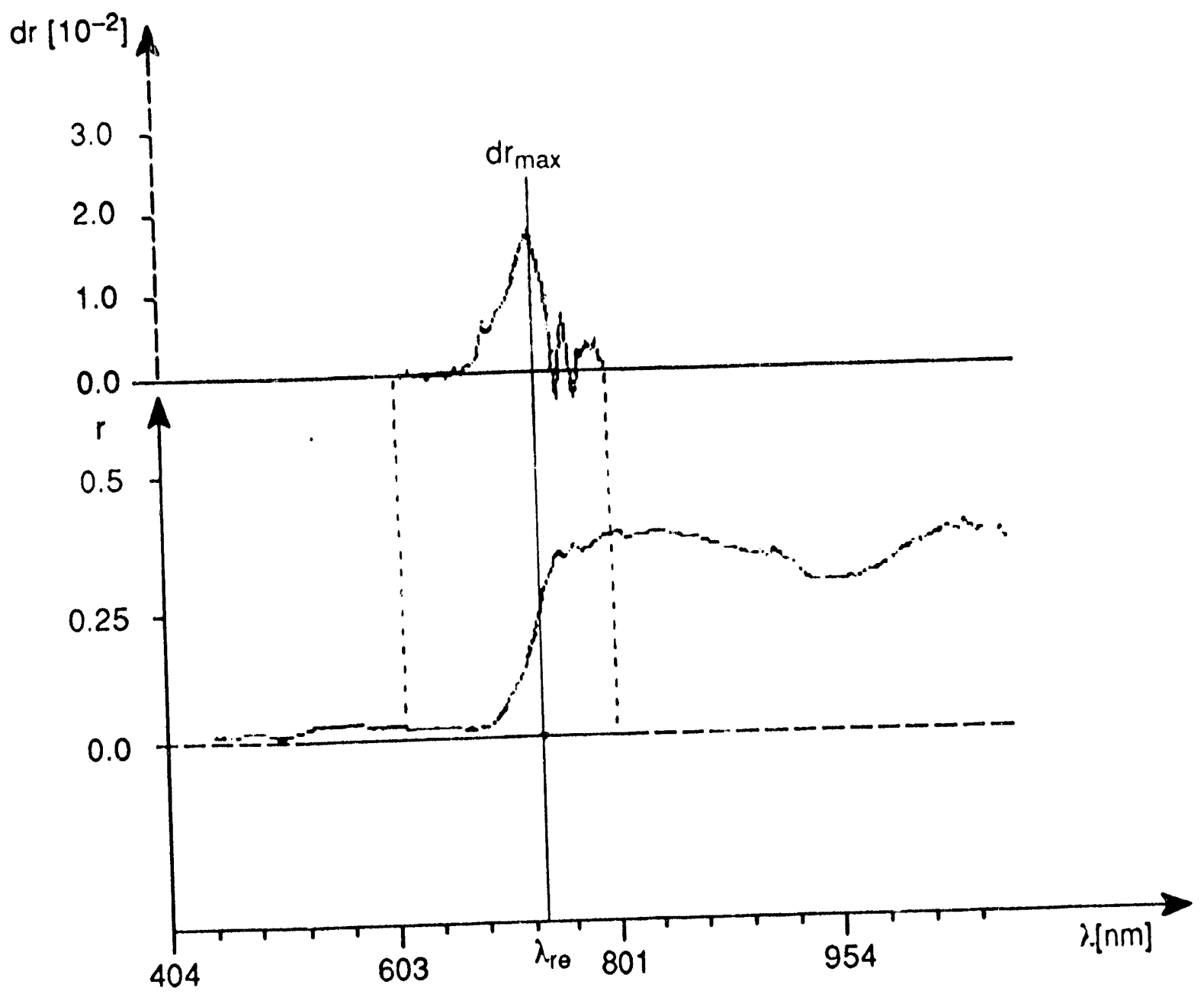

Figure 2.1: Reflectance spectra (bottom) and simple difference spectrum (top) (from Booch et al., 1990).

\section{Laboratory Studies}

Much of the work regarding detection of a horizontal shift in the position of the red edge has been carried out under laboratory conditions. The results from many of these studies are summarized in Table 2-1. The majority of the results show that vegetation stress is evident as a shift in the red edge position toward shorter wavelengths, known as a blue shift. However, observations of shifts towards longer wavelengths have been recorded as well (Milton et al., 1989).

Observation of a blue shift in several studies focusing on plant development has shown the position of the red edge to be related to chlorophyll concentration (Gates et al., 1965; Collins 1978; Horler et al., 1983). Each of these studies, with the exception of Horler et al. (1983), traced the position of the red edge through phenological development, showing that the red edge shifts 
TABLE 2-1: Red cdge shift detection: laboratory studies.

\begin{tabular}{|c|c|c|c|c|c|c|c|}
\hline $\begin{array}{c}\text { AUTHOR } \\
\text { SPECIFS } \\
\end{array}$ & INSTRUMENT & $\begin{array}{l}\text { BAND } \\
\text { WIDTH }\end{array}$ & $\begin{array}{l}\text { SPECTRAL } \\
\text { RANGE }\end{array}$ & $\begin{array}{l}\text { STUDY } \\
\text { TYPE }\end{array}$ & $\begin{array}{l}\text { TARGET } \\
\text { SIZE }\end{array}$ & $\begin{array}{l}\text { LEAF } \\
\text { STACKING }^{\dagger}\end{array}$ & RESULTS \\
\hline $\begin{array}{l}\text { Westman \& Price } 1987 \\
\text { species: jeffery pine, giant } \\
\text { sequoia, Co' rnia } \\
\text { coastal sage urub } \\
\text { species }\end{array}$ & Collins VIRIS & NR & NR & $\begin{array}{l}\text { ozone } \\
\text { sulfur dioxide } \\
\text { fumigation }\end{array}$ & NR & NR & $\begin{array}{l}\text { blue shift, magniaude } \\
\text { not reported }\end{array}$ \\
\hline $\begin{array}{l}\text { Singhroy et al. } 1989 \\
\text { spocics: white birch, } \\
\text { quaking aspen, jack pine, } \\
\text { blue spruce, whise and } \\
\text { red oak }\end{array}$ & Barringer HHRR & $3 \mathrm{~nm}$ & $\begin{array}{l}7 \text { bands@650. } \\
680.703 .713 . \\
743.782 .800 \mathrm{~nm}\end{array}$ & $\begin{array}{l}\text { mineral } \\
\text { stress }\end{array}$ & $6 \mathrm{~cm}^{2}$ & $3+$ & $\begin{array}{l}8 \text { blue shifts up to } 5.8 \\
\mathrm{~nm}, \mathrm{~b} \text { shift to } 5.8 \mathrm{~nm} \text {. } \\
r \text { shift to } 3 \mathrm{~nm} \text {, and no } \\
\text { shift, } 3 \text { red shifts up to } 3 \\
\mathrm{~nm}, 3 \text { no shifts }\end{array}$ \\
\hline $\begin{array}{l}\text { Chang \& Collins } 1980 \\
\text { species: sorghwm, } \\
\text { mustard }\end{array}$ & NR & NR & NR & mineral stress & NR & NR & $\begin{array}{l}\text { blue shift of } 10 \mathrm{~nm} \text { with } \\
\text { low soil conc. } \\
\text { (100 ppm) }\end{array}$ \\
\hline $\begin{array}{l}\text { Milton et al. } 1989 \\
\text { spocies: soybean }\end{array}$ & Beckman 5240 & NR & NR & $\begin{array}{l}\text { arsenic } \\
\text { and selenium } \\
\text { doping }\end{array}$ & $2 \mathrm{~cm}^{2}$ & 1 & $\begin{array}{l}\text { selenium doping } \\
\text { producod } 4 \text { nn red } \\
\text { shift arsenic doping } \\
\text { produced } 1 \text { to } 3 \mathrm{~nm} \\
\text { blue shift }\end{array}$ \\
\hline $\begin{array}{l}\text { Hoque \& Hutzler } 1992 \\
\text { species: Beech }\end{array}$ & Zeis MCS 512 & 2.4 & 680 to 760 & $\begin{array}{l}\text { damage } \\
\text { classes }\end{array}$ & NR & NR & $\begin{array}{l}\text { blue shift up to } 7 \mathrm{~nm} \\
\text { across } 4 \text { damage } \\
\text { classes }\end{array}$ \\
\hline $\begin{array}{l}\text { Milton et al. } 1991 \\
\text { spocies: soybean }\end{array}$ & Beckman 5240 & $1 \mathrm{~nm}$ & 400 to 800 & $\begin{array}{l}\text { Phosphorous (P) } \\
\text { deficiency }\end{array}$ & $2 \mathrm{~cm}^{2}$ & 1 & $\begin{array}{l}\text { blue shift up to } 7 \mathrm{~nm} \\
\text { with } \uparrow P \text { deficiency }\end{array}$ \\
\hline $\begin{array}{l}\text { Horler et al. } 1983 \\
\text { spocies: corn }\end{array}$ & Perkin Elmer 554 & NR & NR & $\mathrm{Cu}, \mathrm{Zn}$ stress & NR & $3+$ & $\begin{array}{l}\text { blue shift, magnitude } \\
\text { not reported }\end{array}$ \\
\hline $\begin{array}{l}\text { Singhroy \& Kruse } 1991 \\
\text { species: white birch, } \\
\text { quaking aspen, jack pine, } \\
\text { blue spruce, whise and } \\
\text { red oak }\end{array}$ & SES90 & $2.8 \mathrm{~nm}$ & 400 to $1.100 \mathrm{~nm}$ & mineral stress & $6 \mathrm{~cm}^{2}$ & $3+$ & $\begin{array}{l}6 \text { blue shifts up to } 9 \mathrm{~nm} \\
2 \text { rod shifts up to } 3 \mathrm{~nm} \\
3 \text { no shifts }\end{array}$ \\
\hline
\end{tabular}

$\dagger=$ number of layers of leaves within spectroradiometer ficld-of-view

NR $=$ not reported

$\mathrm{nm}=$ nanometer 
to longer wavelengths (an IR shift) as plants mature. It was inferred from these results that overall chlorophyll concentration was responsible for the wavelength position of the red edge. Horler et al. (198.3) further documented this relationship by regressing red edge positions $\left(\lambda_{\tau c}\right)$ aganst chlorophyll concentration per leaf area $\left(\mu g / \mathrm{cm}^{2}\right)$. Correlation coefficients $\left(R^{2}\right)$ and significance measures were strong for both monocot and dicot plants.

These studies have provided the basis for using positional shifts of the red edge as an indicator of vegetation stress. As pollution and/or other types of environmental stress impacts plants, a likely consequence is to impact the physiological and/or physico chemical properties of the plant. The net result is often an overall reduction in chlorophyll concentration due to hindered metabolic process (e.g., photosynthesis, respiration). This reduction in chlorophyll should be detectable as a shift in the wavelength position of the red edge.

A valuable property of red edge shifts is its insensitivity to mixed pixel problems. ${ }^{3}$ Horler et al. (198.3) have shown that varying the amount of vegetation and bare ground (i.e., rock or soil) within the spectrophotometer ficld of view or pixel does not appreciably affect the position of the red edge as long as vegetation comprises at least 20 percent (Figure 2.2). This finding has been replicated by Miller et al. (1990) and is important with regard to aerial and satellite remote sensing applications which have spatial resolutions ranging from tens to hundreds of square meters.

While the majority of results in Table 2-1 show a shift to shorter wavelengths, or a blue shift, in the red edge for stressed vegetation relative to control samples, they tend to be rather small, typically less than $10 \mathrm{~nm}$ (e.g., Singhroy and Kruse, 1991; Chang and Collins, 1980; Hogue and Hutzler, 1992; Milton et al., 1991). As these shifts are sometimes not present, or the shift is toward longer wavelengths (an IR shift), it is important to define properties responsible for these variations.

Unfortunately, because of differences in analytical techniques and instrumentation, it is difficult to find a single or suite of characteristics responsible for the variable results. These are in addition to differences in species studied and toxins used, or stresses applied. Indeed, Milton et al. (1989) showed that arsenic doping produced a blue shift while selenium doping produced a red shift in the same species. This emphasizes the need to delineate those species and contaminants that show potential in remote sensing applications.

Horler et al. (1983) showed that leaf stacking (increasing the number of layers of leaves above one within the spectrophotometer field-of-view) shifted the position of the red edge to longer wavelengths. This result is consistent with the results of the phenological studies presented earlier because leaf stacking places more chlorophyll within the field -of -view, thereby simulating increased chloluphyll concentrations due to phenological leaf development

\footnotetext{
${ }^{3}$ Mixed pixel refers to the phenomenon where more than one carth surface feature (c.g., vegetation, soil, Hater) contributes significantly to the signal received for that field of-view or picture element (pixel). Current research is focusing on the ability to distinguish the contribution to the signal of each surface fealure for a mixed pixel.
} 


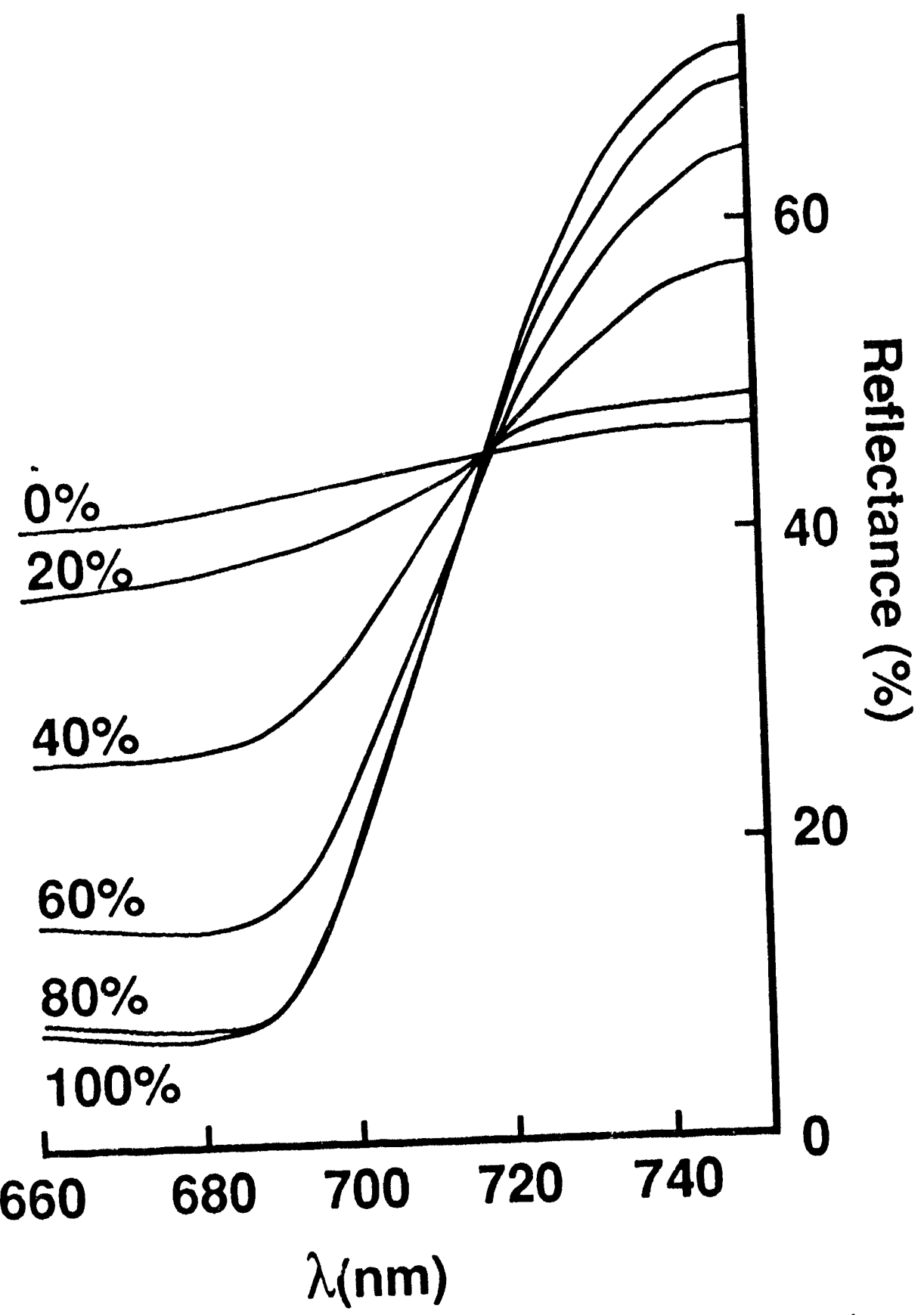

Figure 2.2: Change in the position of the red edge inflection point $(\lambda r e)$ as amount of vegetation is reduced from 100 to 0 percent (reprinted from Horler et al., 1983).

and maturity. Increasing leaf stacking above one layer may increase the overall chlorophyll concentration of both stressed and control samples, potentially decreasing the magnitude of the difference between them. Westman and Price (1987) showed that infrared reflectivity reaches an asymptote at seven to eight leaf layers, which further supports this position. Singhroy et al. 
(1989) and Singhroy and Kruse (1991) were the only studies using a leaf stack greater than one, and the only studies that reported instances of no shift between stressed and control samples.

\section{Ficld and Airborne Studies}

There have been relatively few red edge shift detection studies undertaken that have utilized field-measured spectral data (Table 2-2), and even fewer using airborne-measured data (Table 2-3). Notwithstanding the greater expense of data collection, the reasons for the few number of red edge shift detection studies using field-or airborne collected data seem to be twofold. First, the high spectral resolution necessary to detect horizontal shifts in the wavelength position of the red edge is not readily available on most airborne remote sensing instrumentation. Ideally, many spectral measurements are needed along the entire red edge slope ( $\approx 670$ to 760 $\mathrm{nm}$ ). The majority of airborne systems do not have spectral resolution finer than $10 \mathrm{~mm}, 4$ which is approximately the maximum magnitude of red edge shifts reported in the literature (Singhroy and kruse, 1991). Second, removing spectral measurements from the laboratory into the hield introduces confounding effects of variations in atmospheric conditions, and canopy and illumination geometry. Table 24 tallies a number of studies that have investigated red edge shifts, according to whether they used laboratory measurements, field-, or airborne-rollected data. Undoubtedly, many more field and airborne studies will take place in the near future as instrumentation development continues and the need for regional assessment of vegetation increases.

Most researchers have recognized the potential for atmospheric, canopy and illumination geometry effects to complicate the application of red edge shift detection studies (Schwaller, 1982; Chang and Collins, 1980; Collins et al., 1983; Shutt et al., 1984; Vanderbilt et al., 1985; Vanderbilt et al., 1988; Curtiss and Maecher, 1991). The results in Table 2-2 reflect to some extent the potential impact of these environmental parameters. Only two of the five studies (Demetriades-Shah and Steven, 1988; Curtiss and Maecher, 1991) conducted their experiments at the canopy level. Of these two, only Curtiss and Maecher (1991) attempt to control for differences in canopy and illumination geometry, by using principal components analysis. The significance of their results is that they indicated a shift of the red edge, while those of Demetriades-Shah and Steven (1988) did not. The three remaining studies collected spectral data at the branch level, which effectively eliminates any canopy and illumination geometry, and atmospheric effects.

The impact of a variable environment (e.g., atmospheric, canopy and illumination geometry) on the detection of red edge shifts between stressed and control sites is even more evident among the studies utilizing airborne data (Table 2-3). While two of the three studies

${ }^{4}$ Rock et al. (1988) used the Fuorescence Line Image (FL.I) to collect their airhorne data. The Fl.l has a spectral resolution of approxinately $2.6 \mathrm{~nm}$, and was manufacured by Moniteq, Lid. A more complete description of the system is found in Hollinger et al. (1985). Also, Collins $\mathrm{ct}$ al. (1983) used the Mark I system, which collects spectral data for 500 wavebands across the 450 to $1,100 \mathrm{~nm}$ portion of the EM spectrum in 1.4 $\mathrm{nm}$ bands. Description of the Mark I system is found in Chui and Collins (1978). 
TABLE 2-2: Red edge shift detection: ficld studics.

\begin{tabular}{|c|c|c|c|c|c|c|c|}
\hline $\begin{array}{l}\text { AUTHOR } \\
\text { SPECIES }\end{array}$ & INSTRUMENT & $\begin{array}{l}\text { BAND } \\
\text { WIDTH }\end{array}$ & $\begin{array}{l}\text { SPECTRAL } \\
\text { RANGE }\end{array}$ & $\begin{array}{l}\text { SAMPLING } \\
\text { DISTANCE }\end{array}$ & $\begin{array}{l}\text { STUDY } \\
\text { TYPE: }\end{array}$ & $\begin{array}{l}\text { TARGET } \\
\text { SIZE }\end{array}$ & RESULTS \\
\hline $\begin{array}{l}\text { Buschmann et al. } 1989 \\
\text { species: spruce }\end{array}$ & VIRAF & NR & 400 to $800 \mathrm{~nm}$ & NR & $\begin{array}{l}\text { damage } \\
\text { (forest } \\
\text { decline) }\end{array}$ & NR & $\begin{array}{l}\text { 1) no shift for current } \\
\text { year needles } \\
\text { 2) } 4 \text { nm blue shift for } \\
\text { 1-year-old needles } \\
\text { 3) } 10 \text { nm shift for } \\
\text { 2-year old needles }\end{array}$ \\
\hline $\begin{array}{l}\text { Rock et al. } 1988 \\
\text { spocies: spruce }\end{array}$ & VIRIS & $2 \mathrm{~nm}$ & 400 to $: .000 \mathrm{~nm}$ & NR & air pollution & $1 \times 3 \mathrm{~cm}$ & $\begin{array}{l}\text { 1) } 5 \mathrm{~nm} \text { blue shift for } \\
\text { current year needles } \\
\text { 2) } 5 \mathrm{~nm} \text { blue shift for } \\
\text { 3-year-old needles }\end{array}$ \\
\hline $\begin{array}{l}\text { Curtiss \& Maecher } 1991 \\
\text { species: lodgepole pine }\end{array}$ & PSII & 2.7 & $\begin{array}{l}350 \text { to } 1.050 @ \\
1.3 \text { nm internals }\end{array}$ & $50 \mathrm{~m}$ & $\begin{array}{l}\text { stress } \\
\text { arsenic, } \\
\text { lead, zinc }\end{array}$ & NR & $\begin{array}{l}\text { blue shift, magnitude } \\
\text { not reported }\end{array}$ \\
\hline Curtiss \& Ustin 1989 & PIDAS & $\begin{array}{l}1 \mathrm{~nm} \\
5 \mathrm{~nm}\end{array}$ & $\begin{array}{l}400 \text { to } 900 \mathrm{~m} \\
900 \text { to } 2450\end{array}$ & $0.5 \mathrm{~m}$ & ozone & $10 \mathrm{~cm}$ & $\begin{array}{l}\text { red shift with ozone } \\
\text { damage } \uparrow\end{array}$ \\
\hline Karr \& Mouat 1990 & HHRR & $10 \mathrm{~nm}$ & $\begin{array}{l}675 \text { to } 775 \mathrm{~nm} \\
\text { used }\end{array}$ & $1.0 \mathrm{~m}$ & $\begin{array}{l}\text { acid wastes } \\
\text { heavy mitals }\end{array}$ & $10 \mathrm{~cm}$ & $\begin{array}{l}\text { blue shift with increasing } \\
\text { concentration }\end{array}$ \\
\hline
\end{tabular}

$\dagger=$ distance between spectrometer and targei 
TABLE 2-3: Red edge shift detection: airbome studies.

\begin{tabular}{|c|c|c|c|c|c|c|c|}
\hline $\begin{array}{l}\text { AUTHOR/ } \\
\text { SPECIES }\end{array}$ & INSTRUMENT & $\begin{array}{l}\text { BAND } \\
\text { WIDTH }\end{array}$ & $\begin{array}{l}\text { SPECTRAL } \\
\text { RANGE }\end{array}$ & $\begin{array}{l}\text { PIXEL } \\
\text { SIZE }\end{array}$ & $\begin{array}{l}\text { \# OF PIXELS } \\
\text { PER TARGET }\end{array}$ & $\begin{array}{l}\text { STUDY } \\
\text { TYPE }\end{array}$ & RESULTS \\
\hline $\begin{array}{l}\text { Ambrosia et al. } 1991 \\
\text { species: ponderosa pine }\end{array}$ & AVIRIS & $\begin{array}{l}9.7 \text { to } \\
11.6 \mathrm{~nm}\end{array}$ & 400 to 2.450 & NR & 154 to 375 & $\begin{array}{l}\text { drougght and } \\
\text { pest damage }\end{array}$ & no shift evident \\
\hline Leprieur 1989 & AVIRIS & $9.8 \mathrm{~nm}$ & 400 to 2,450 & $20 \mathrm{~m}$ & 2010309 & $\begin{array}{l}\Lambda \text { in red odge } \\
\text { with } \Delta \text { in } \\
\text { vegetation }\end{array}$ & $\begin{array}{l}\text { T in red edge frumn } 705 \\
\text { to } 721 \mathrm{~nm} \text { acrow.. s siles }\end{array}$ \\
\hline Rock et al. 1988 & FLI & $2.6 \mathrm{~nm}$ & 400 to 800 & $\mathrm{~K} \times 17 \mathrm{~m}$ & NA & arr polliution & $\begin{array}{l}\text { I nm blue shifi. but this } \\
\text { magnitude wav twh } \\
\text { larger than wavelength } \\
\text { standard deviation } \\
\text { values }\end{array}$ \\
\hline
\end{tabular}

NA $=$ not applicable

$\Delta=$ change

$\uparrow=$ increase 
TABLE 2-4: Trends in detection of shifts in the red edge. ${ }^{\dagger}$

\begin{tabular}{|c|c|c|c|}
\hline STUIDYSCAIE & $\begin{array}{l}\text { BLUE } \\
\text { SHIFT }\end{array}$ & $\underset{\text { IIIIFT }}{\text { IR }}$ & $\begin{array}{c}\text { NO } \\
\text { SIIIFT }\end{array}$ \\
\hline Laboratory & 21 & 6 & 6 \\
\hline Field & 6 & 1 & 2 \\
\hline Airborne & 2 & 0 & 1 \\
\hline $\begin{array}{l}\text { The tallies are bas } \\
\text { results for several } \\
\text { shifts riported is }\end{array}$ & $\begin{array}{l}\text { reported in th } \\
\text { results were } \\
\text { tudies listed }\end{array}$ & $\begin{array}{l}\text { orts ciled. In sor } \\
\text { ted across time. } \\
\text { les } 2-1,2-2 \text {, at }\end{array}$ & $\begin{array}{l}\text { es, wuthors reported } \\
\text { fore, the number of }\end{array}$ \\
\hline Shifte less than 1 & & & \\
\hline
\end{tabular}

reported shifts, only Lepricur (1989) attempted to account for environmental constraints, such as atmospheric parameters, sun position, and canop: architecture. Illumination effects were controlled by acquiring all data at the same solar time. Atmospheric path length effects were controlled by application of the SS model (Tanre et al., 1986), and canopy geometry effects by application of the SAIL model (Verhoef, 1984). While the number of airborne studies are too few for any broad conclusions, two of the three groups reported success that would focus greater scrutiny in those areas of suspected stress. This could have great economic benefit to ERWM activities.

A final observation pertaining to Table 2-2 is that Buschmann et al. (1989) reported an increasing magnitude in the blue shift with increasing duration of exposure. This is intuitive and may have significant application at sites with a history of contamination. While temporal effects have received little attention in the remote sensing literature, they may dictate the timing and repetition of remote sensing acquisition efforts.

\section{Wave-Form Analysis}

Collins et al. (1983) developed a technique for detecting vegetation stress that is a modification of the red edge shift detection technique previously discussed. The technique is called wave-form analysis, and is generally applied to airborne measurements with sufficient spectral resolution. The equation for calculation of the SDS can be summarized as function such as:

$$
F(a+x)=\sum_{i=0}^{i=N} A_{i} X_{i}
$$


where $X$ is the reflectance at wavelength $i$, and $A$ is a coefficient that changes as $i$ changes and $(a+x)$ describes the change in reflectance $X$ as wavelength (i) changes across the spectral region from i io $\mathrm{N}$.

Collins et al. (1983) point out that background variations (canopy effects and topography) can cause variations in reflectance significantly greater than variations due to vegetation stress: they modified the above equation as follows:

$$
F(x)=\sum_{i=0}^{i=N} A_{i} T_{i} X
$$

where $T_{j}(X)$ is a polynomial. Hence, the primary difference between the simple difference equation and the wave form equation is that the wave-form uses a polynomial $\left(T_{i}\left(X^{\prime}\right)=a_{1}-a_{2} X\right.$ $\left.+a_{3} x^{2} \ldots\right)$ to estimate the difference in magnitude in reflectance hetween adjacent wavelengths, while the simple difference lechnique calculates this difference directly. Collins et al. (1983) use the Chebyshev polynomial for $T_{i}(X)$. The Chebyshev polynomial was selected because it is sensitive to lower frequency changes (the small changes in a spectral profile due to vegetation stress) while ignoring higher frequency changes (shifts in the spectral profile resulting from a variable canopy or topography).

After calculating a series of Chebyshev polynomials, principal components analysis was used to study the variance. It was found that 10 coefficients captured nearly all the variance, that is, 10 cocfficients $\left(a_{1}\right.$ to $a_{10}$ ) were nceded in the polynomial to model the reflectance. Collins et al. (1983) found that sulfide toxicity in vegetation could be detected using ratios of the 9 th and 5 th coefficients, while canopy effects were evident in ratios of the 8 th and 4 th coefficients. Their method is important in that it allows the identification of various aspects responsible for reflectance features observed in collected spectra. Furthermore, it was developed specifically for data collected by the high resolution Mark I airborne spectroradiometer. The Mark I spectroradiometer acquires a 500-channel profile in $1.4 \mathrm{~nm}$ wavebands across the 400 to 1,100 $\mathrm{nm}$ region and is described more fully by Chui and Collins (1978). This suggests that as data from other high resolution instruments (e.g., Airborne Visible/lnfrared Imaging Spectrometer (AVIRIS) and Compact Airborne Spectrographic Imager (CASI)) become more widely available, new methods will be developed that more easily allow the detection of vegetation stress.

\section{Inverted Gaussian Model}

Singhroy and Kruse (1991) point out that shifts in the wavelength position of the red edge are generally small and would require spectral resolution beyond the capability of most airborne and satellite sensors for detection. However, a technique introduced by Hare et al. (1984) and Miller et al. (1985) calculates the red edge slope (see Figure 1.3) using only four data points, allowing red edge calculations with data from lower resolution, airborne sensors. The equation, called the inverted Gaussian (IG) function, is reprinted here from Miller et al. (1990): 


$$
R(\lambda)=R_{s}-\left(R_{s}-R_{0}\right)-\left(\lambda_{0}-\lambda\right) / 2 s
$$

where $R_{S}$ is the maximum reflectance shoulder) in the near $I R$ region, $R_{0}$ is the minimum reflectance in the chlorophyll absorp: an (red) region, $\lambda_{0}$ is wavelength of peatk absorption (minimum reflectance, $R_{0}$, in the red region), $\lambda$ is wavelength, and 0 is the distance betw cen the wavelength of maximum absorption ( $\left.i_{*}\right)$ in the red region and the wavelength of the red edge inflection point $\left(\lambda_{\text {Te }}\right)$ (Gaussian function derivation parameter). These parameters are graphically presented here in Figure 2.3 where $\lambda_{T c}$, the wavelength of the red edge inflection point, is labeled $\lambda_{p}$.

Initial estimates of $R_{s}, R_{0}, \lambda_{0}$, and $\sigma$ are made, and the equation is iterated by incremental increatses in $\lambda$ (e.g., $1 \mathrm{~nm}$ ) to determir $\geq R(\lambda)$ for that $\lambda$. Once the iteration is complete for the spectral region being estimated (e.g., $6.710810 \mathrm{~nm}$ ), the iteration is repeated by incrementing $\rangle_{\text {. }}$. $\sigma$, and $R_{s}$ in turn and in that order. The :- - remental steps suggested for $\lambda_{0}, \sigma$, and $R_{s}$ are $(0.10 \mathrm{~mm}$, $0.03 \mathrm{~nm}$, and 10 percent, respectively. Miller et al. (1990) note that the initial values selected and the spectral range chosen must be given careful consideration. When iterations are complete. least squares criterion are used to dete.mine the best fit. $R(\lambda)$ values calculated from the least squares analysis are then used to calcL'ate the SDS and the red edge inflection point.

Miller et al. (1990) successfully afplied the IG fitting procedure to laboratory spectra of bur oak (Quercu macrocarpa) (Figure 2.3). Additional comparisons between laboratory spectra and data collected from the MEIS II airborne sensor for balsam fir (Abies balsamea) and sugar maple (Acer saccharum) also showed good agreement. While the authors indicate that the iterative, model-fitting characteristics of IG offer some ability to control for atmospheric effects as well, it should not be considered as a substitute for high resolution data when available.

\section{Summary and Conclusions}

Detection of wavelength shifts in the location of the red cdge is a technique that has been widely applied in remote sensing of ve Eetation stress. Through a large weight of evidence, a shift in the red edge to shorter wavelengths can be linked to lower overall chlorophyll concentration in stressed verses control vegetation samples. The red edge shift technique, as reported by Horler et al. (1983) and Miller et al. (1990), also has the advantage of being insensitive to mixed pixel problems. This insensitivity to mixed pixels may be a significant advantage when analyzing data from airborne and satellite platforms, specifically over arid regions.

The results, however, do not constitute a panacea. Incidents of no shift and shifts to longer wavelengths have also been reported. The variable results, to some degree, can be attributed to the variable methorlological practices as indicated in Tables 2-1, 2-2, and 2-3. However, if shifts in the red edge towards longer wavelengths can be accurately characterized for specific plants and contaminants, they may be just as valuable as documented blue shifts in the application of remote sensing for vegetation stress detection. Of greater concern is the small number of studies to apply these techniques with spatial or airborne data while accounting for environmental 


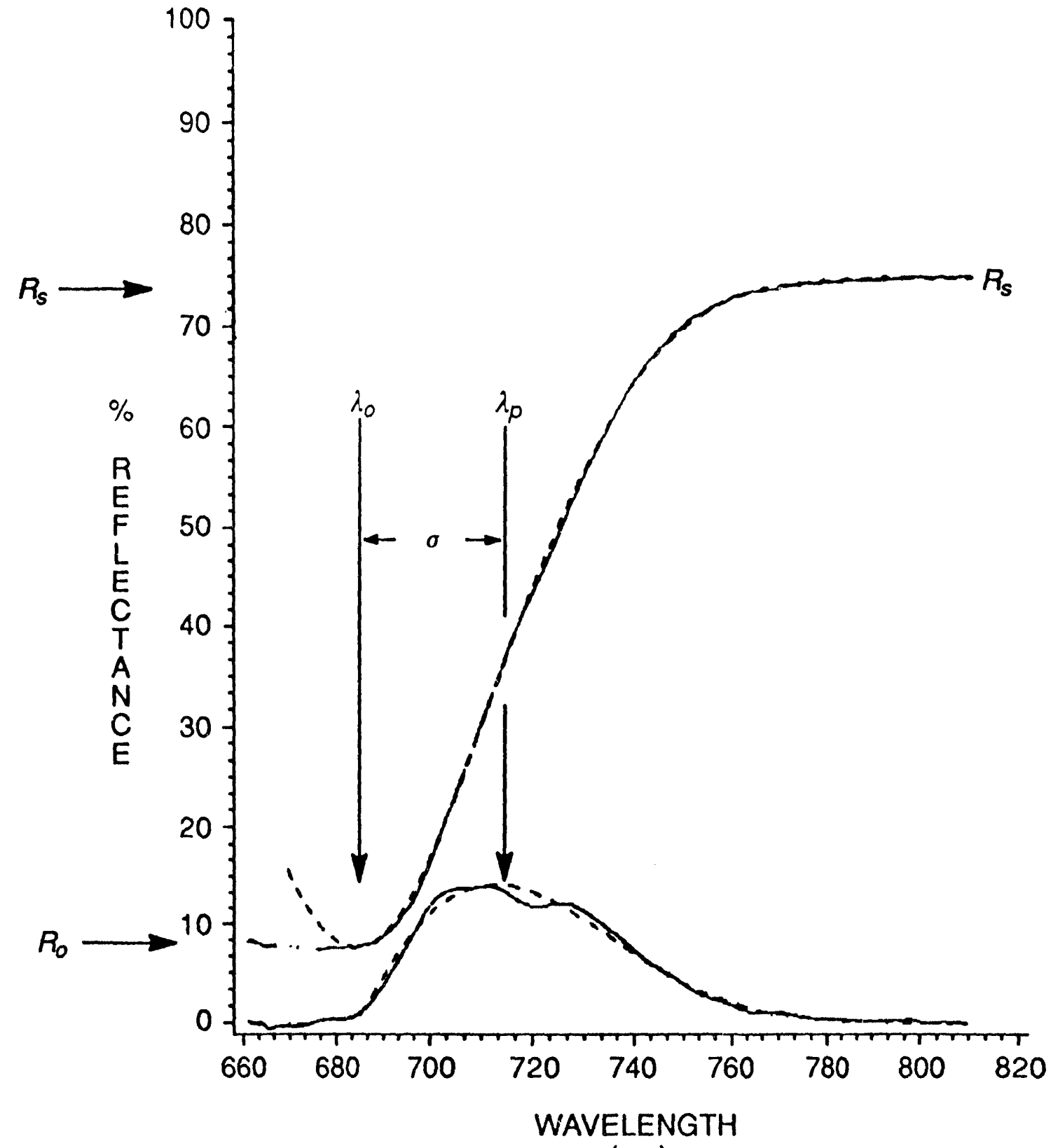

(a) $(\mathrm{nm})$

Figure 2.3: Graphic representation of IG function parameters, and comparison of IG modeled (dashed line) and measured (solid line) reflectance (top) and simple difference (bottom) spectra (reproduced from Miller et al., 1990). 
parameters (e.g., atmosphere, canopy and illumination geometry). This can be explained mostly due to a lack of high resolution instruments available and costs associated with acquisition.

Many of the studies reviewed did not discuss the influence of time on spectral measurements. Buschmann et al. (1989) presented time series showing spectral evidence of increasing stress in second and third year conifer needles exposed to very low concentrations of air pollution (Table 2-5), while Gates et al. (1965), Collins (1978), and Horler et al. (1983) presented changes in the red edge position as a function of phenological development. It is clear that temporal effects of red edge phenomena must be considered when planning data collection efforts and may require annual to seasonal acquisition for successful identification of stressed vegetation.

Rock et al. (1988) note that spectral measurements in the field include vegetation injury characteristic of the site, but do not quantify how that damage was assessed. Curtiss and Maecher (1991) presented evidence showing no clear relationship between visible symptoms of stress (e.g., needle/leaf yellowing and/or lack of retention) in samples from toxic and control sites. Since the red edge phenomena spans from the visible to the IR or nonvisible region of the EM spectrum, it is intuitive that instruments recording in these regions may allow the detection of subtle changes indicative of stress before they are visible to the human eye. Furthermore, recently developed airborne instruments can digitally record differences and detect changes in both visible and NIR regions with greater sensitivity than the human eye. These differences can then be easily highlighted through the use of computer image processing techniques for visible distinction. These qualities would suggest the use of more recently developed instruments in addition to, or instead of, traditional aerial photography in a remote sensing program.

TABLE 2-5: Time-series spectral data of stress and control samples (from Buschmann et al., 1989).

\section{RED-EDGE INFLECTION POINT}

\begin{tabular}{lccc}
\hline Samples & 1988 & 1987 & 1986 \\
Control & 707 & 704 & 707 \\
Stress & 707 & 700 & 697 \\
\hline
\end{tabular}

Collins et al. (1983) developed wave-form analysis to model the red edge profile ( $\approx 670$ to $760 \mathrm{~nm}$ ) using a 10th-order polynomial. Their justification for this was that environmental effects on reflectance, such as canopy geometry and topography, introduced variations in reflectance that are much greater than variations due to stress such as metal toxicity. The methodology appears successful, but has been used by few other researchers. Lack of wider use of this technique is most likely the result of its development for a specific high resolution spectroradiometer that has had limited availability to other researchers. 
A second technique, the IG function, was introduced by Hare et al. (1984), Miller et al. (1985) and Miller et al. (1990). It has the advantage of being able to model the red edge profile using only four data points, allowing red edge studies with lower spectral resolution instrumentation. Like the wave-form technique, IG is reported to be able to partially control for the affects of atmospheric, canopy geometry and illumination changes on reflectance. Perhaps IG's most significant contribution is in defining other critical points along the vegetation spectril profile; the IR reflectance shoulder, $R_{s}$; the chlorophyll well reflectance minimum, $R_{o}$; and the wavelength of the reflectance minimum, $\lambda_{0}$. Much of the data presented in the literature indicates that these parameters along with the red edge position, when considered as a whole, may provide greater reliability in predicting vegetation stress. While it is noted that the IG function represents an approach for using coarser resolution airborne data, it is an estimation technique that does not replace high resolution data when available.

The reported success of both the wave-form and IG modeling techniques is to some degree the result of accounting for atmospheric, illumination, and canopy effects on measured spectrial reflectance. The importance of controlling for these effects cannot be discounted and may dictate the success or failure of an investigation.

Many techniques similar to those discussed are well developed for other uses in industrial applications and in the field of spectroscopy where high resolution instrumentation is readily available. As technological developments continue to improve remote sensing instrumentation, these techniques will no doubt become more widely used and accepted in remote sensing investigations. 


\subsection{FULL SPECTRAL MATCHING AND FLUORESCENCE}

The inverted Gaussian (IG) model previously discussed introduces three new variables as important characteristics of a vegetation spectral profile: $R_{s}, R_{0}$, and $\lambda_{0}$. Each of these variables, along with the wavelength of the red edge inflection point $\left(\lambda_{\text {Te }}\right)$, represents a parameter that may be exploited in some fashion to determine the status of vegetation. Examining several critical points or the entire continuum along the vegetation spectral profile constitutes another approach to the detection of vegetation stress. Such an approach, referred to here as full spectral matching, is evident in the literature and in the field of spectroscopy, but is less frequently' used in the field of remote sensing due, in part, to the low spectral resolution of most systems.

\section{Full Spectrai Matching}

Both Singhroy and Kruse (1991) and Curtiss and Maecher (1991) point to the value of examining the depth (magnitude of absorption) and breadth (number of wavelengths) of the chlorophyll absorption band (red region of the EM spectrum) for the detection of vegetation stress. Singhroy and Kruse (1991) present a methodology for defining these parameters. Milton et al. (1989) report that arsenic and sclenium doped plants showed an increase and decrease, respectively, in reflectance in the 550 to $660 \mathrm{~nm}$ (green) region of the EM spectrum when compared to control samples. Ager et al. (1989) similarly reported an increase in reflectance in the 550 to $650 \mathrm{~nm}$ region for metal--stressed vegetation growing in northeastern Minnesota. Rock et al. (1988), using the IG model, reported significant differences in $R_{s}, R_{0}$, and $\lambda_{0}$ parameters between high and low damage sites. This signifies the importance of operationally using the best instrument available, analytical techniques appropriate to the data collected.

Other studies have looked at statistical differences in percent reflectance between stress and control sites or sainples, using selected critical wavebands. Leckie et al. (1992) reported an $R^{2}$ of 0.91 between defoliation levels and the MEIS II blue spectral band $(\approx 430$ to $460 \mathrm{~mm})$. Karr and Mouat (1990) used Student- $-\mathrm{t}$ tests to show a significant difference between stress and control sites, using Landsat Thematic Mapper (TM) replicated wavebands. Mouat (1982) presents an example of the intent of full spectral matching. Citing Siegal and Gillespie (1980), he presented full spectral profiles for damage and control samples of red spruce (Picea rubens) and balsam fir (Abies balsamea), showing where profiles were significantly different through the use of 95 percent confidence intervals. These results are reproduced here as Figure 3.1.

Confidence intervals can be easily constructed for a sample of spectral profiles, using the standard equation (see, for example, Brower and Zar, 1977):

$$
\mu=X \pm t s_{x}
$$

where $\mu$ is the population mean, $X$ is the sample mean, $t$ is a constant taken from the Student- $t$ table (value dependent on significance level and degrees of freedom), and $s_{\mathbf{x}}$ is the standard error of the sample mean. This simple technique will allow statements of statistical confidence pertaining to measured differences in the magnitude of reflectance between stress and control 


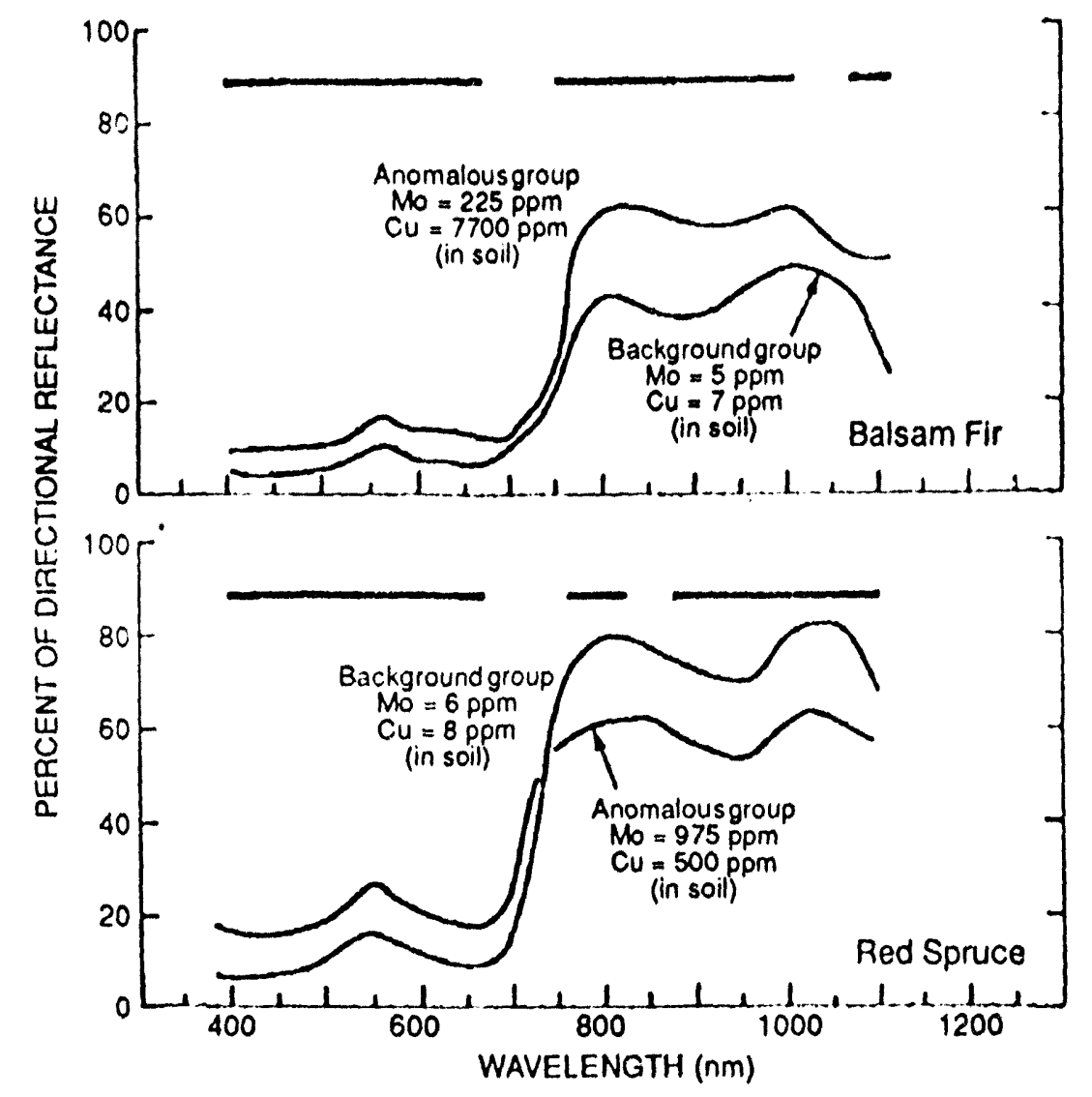

Figure 3.1: Difference in reflectance spectra for control (background) and stress (anomalous) balsam fir and red spruce samples. Thick black lines at top of the spectra show wavelength regions where stress and control samples are significantly different at 95 percent confidence interval (reproduced from Mouat, 1982).

sites/samples. Graphical presentations of the differences in the spectral profiles between stress and control vegetation are numerous in the literature, but statements of confidence pertaining to these differences are often lacking.

\section{Fluorescence}

The plant property of fluorescence has also been used to detect vegetation stress. Fluorescence is the emittance of red light by plants upon excitation of the chlorophyll molecules by higher energy light, namely blue light. The emittance of red light is caused by the rapid decay of electronic energy. Light, essentially, drives electrons away from the nucleus of the chlorophyll molecule, and the distance the electrons are driven away is a function of the energy contained in the radiant flux. As stated in the Introduction, blue light has more energy than red light and is, therefore, able to drive electrons further away from the nucleus. The farther the electron is 
driven, the more likely fuoresence will occur. The phenomenon of fluorescence is difficult to visualize without the aid of graphics. it is discussed again in Chapter 6 under Photosymthesis, where graplics are included.

The property of fluorescence has been exploited to detect vegetation stress by calculating rattios of the light enitted at $\approx 690 \mathrm{~nm}$ versus that e mitted at $\approx 7.30 \mathrm{~nm}$. A decrease in the ratio has been interpreted as a sign of vegetation stress, as reduced fuorescence in the $690 \mathrm{~nm}$ region suggests an overall lower chlorophyll content. This research has been primarily carried out by Buschmann and Lichtenthaler (the references cited section of Buschmann et al. (1989) lists 11 fluorescence publications that include one or both of these authors), with some work by Chapelle (e.g., Chapelle and Williams, 1987; Chapelle et al., 1991). While a very promising technique, fluoresence has not been widely applied by other researchers in the remote sensing community, due mostly to the fact that fluorescence requires active as opposed to passive remote sensing. Since fluorescence requires radiating plants with an energy source, ypically lasers, instrumentation for its use is relatively complex, expensive, and rare. While this may limit its wide scale application in the near term, future development may increase its availability.

\section{Summary and Conclusions}

The introduction of the three additional points along the vegetation spectral profile, in addition to the red edge inflection point $\left(\lambda_{\text {Te }}\right)$, indicates that a more confident detection of vegetation stress can be ascertained by gathering a "full weight of evidence" through use of the entire profile. Full spectral matching, as presented by Mouat (1982), is an example of using all the "vertical" or reflectance data in the spectral profile. An addition to this teclinique would be the inclusion of "horizontal" or wavelength shifts where appropriate.

Finally, detection of vegetation stress using fluorescence was presented. This technique has not been widely applied, due to its requirement for active remote sensing instrumentations. llowever, research is continuing, as its application for stress detection is promising. 


\subsection{RATIO TECLINIQLES}

Ratio technigues are methods that have been developed to expose relationships of spectril rellectance befween different regions in the electrombanetic (EM) spectrum. They are typically peiformed by dividing the reflectance values in one band (or region) by corresponding reflectance values in another band. The closer the resulting value is 10 one, the more similar reflectance values are between bands and vice versa. Ratio techniques have been successfully applied in both mincral and vegetation investigations using both point and spatial data.

The use of ratio techniques probably has been the most widely applied approach to the study of numerous aspects of vegetation dynamics, including pest damage (e.g., leckie et al., 1992), changing leaf area index valucs along a vegetation gradient (Running et al., 1986; Peterson et al. 1987), desertitication (Tucker and Justice, 1986; Townshend and Justice, 1986), phenological eycles (Goward et al., 1985), and detection of moisture stress (e.g. . Ambrosia et al., 1991). Richardson and Everill (1992) reviewed several ratio lechniques, which are presented in Table 4-1. The numerous ratio techniques listed ard the length of time each has been in use

TABLE 4-1: Ratio techniques (from Richardson and Everitt, 1992).

\begin{tabular}{|c|c|c|}
\hline NAME & VEGETATION INDEX (VI) & SOURCE \\
\hline Ratio VI & $R V I=N I R / R E D$ & Pearson and Miller (1972) \\
\hline Normalized Difference VI & $N D V I=(N I R-R E D) /(N I R+R E D)$ & Rousc ct al. (1974) \\
\hline Greenness VI & GVI(RED, NIR) - PVI & Kauth and Thomas (1976) \\
\hline Difference VI & $D V I=N I R-a$ RED & Richardson and Wicgand (1977) \\
\hline $\begin{array}{l}\text { Perpendicular Vegetation } \\
\text { Index }\end{array}$ & $P V I=\frac{\text { NIR }-a R E D-b}{\operatorname{SQRT}\left(1+a^{2}\right)}$ & Richardson and Wicgand (1977) \\
\hline Soil Adjusted VI & SAVI $=\frac{(1+L)(N I R-R E D)}{(N I R+R E D+L)}$ & Hucle (1988) \\
\hline $\begin{array}{l}\text { Transformed Soil } \\
\text { Adjusted VI }\end{array}$ & TSAVI $=\frac{a(N I R-a R E D-b)}{\text { RED }+a N I R-a b}$ & Baret ct al. (1989) \\
\hline Soil Adjusted Ratio VI & $S A V I_{2}=\frac{N I R}{(R E D+b / a)}$ & Major ct al. (1990) \\
\hline
\end{tabular}

illustrate the comparatively long history of application these techniques have enjoyed. Furthermore, the introduction of one ratio technique has stimulated the development of another. The history of ratio techniques and continuing development is in large part due to their successful and easy application with satellite data, and its 20-year availability. 
One of the most common!y used ratio techniques places near infrared (NIR) reflectance in the numerator and red reflectance in the denominator (NIR/red, e.g., TM bands TM4/TM3). The rationale for wide application of this technique is evident in Figures 1.2 and 1.3. Vegetation is highly reflective in the NIR resion and strongly absorbing in the red region. NIR/red ratios guantify the magnitude of difference in reflectance in the two regions, and variations in the difference of this mignitude cin he used to study various aspects of vegetation dy namics, such as those mentioned above. It can also distinguish between vegetation and rock/soil since these surfaces display relatively littls difference between the red and NIR regions of the EM spectrum.

\section{Forest Decline Studies}

The studies utilizing ratio techniques to examine vegetation parameters are extensive (Rocket al., 1986; Petersenct 3... 1988; Running and Nemani, 1988; Williams and Nelson, 1984; Tenmikoon et al., 1992; Mit:on and Rollin, 1988). In general, ratio technigues have been successful in the identification and guantification of vegetation stress. The major difference between ratio lechniques and tose previously discussed is the types of data they are applied to and the magnitude of vegetution stress detected. Most vegetation stress studies use ratio techniques which are employed on instrument data with relatively wide band passes.

Some results of seven forest pest damage studies are presented in Table 4 2. These studies nearly exclusively use Landsat TM satellite data, and have been undertaken primarily on New England forests (Rock et al., 1986). Table 4-2 includes two columns (Air Photo Reference and Visual Estimate of Damage), which were generally not available for studies listed in Tables 2-1, 2-2, or 2-3. The fact that the information contained in these two columns was routinely reported for these studies and not for the studies in Tables 2-1, 2-2, or 2-3 sugges's that the magnitude of stress is much greater in the studies utilizing ratio techniques. In each of the studies in Table 4-2, stress was calculated as the amount of foliage lost. Foliar loss was explicitly measured, and visually observed in aerial photography and satellite imagery. Moreover, the use of the word "stress" is generally lacking and, instead, replaced by the word "damage." As noted in the summary and conclusions to Chapter 2 , most of the higher resolution studies did not report visual differences between stress and control samples.

It should also be noted that mosi of the studies presented in Table 4-2 applicd some kind of radiometric adjustment to control for atmospheric and other environmental effects. As stated previously in Chapter 2, methods for controlling for atmospheric, canopy, and illumination effects are an important aspect in the ability to discriminate vegetation stress in spectral data acquired above the canopy. Since these methods have already been developed, their successful use with high resolution data, as it becomes more widely available, is promising.

\section{Ratio Techniques Versus Wavelength Shifts}

There is an interesting relationship between ratio techniques, which quantify the difference in reflectance between two portions of the EM spectrum, and the suite of techniques which focus 
TABLE 4-2: Ratio and similar techniques applied to forest damage detections from airbornc or satellite platforms.

\begin{tabular}{|c|c|c|c|c|c|c|c|c|}
\hline ACTHOR & INSTRLMENT & $\begin{array}{l}\text { PIXEL } \\
\text { SIZE }\end{array}$ & $\begin{array}{l}\text { PIXFL } \\
\text { SAMPLE }\end{array}$ & $\begin{array}{l}\text { RADIOMETRIC } \\
\text { CONTROL }\end{array}$ & $\begin{array}{l}\text { AIR PHOTO } \\
\text { REFERENCE }\end{array}$ & $\begin{array}{l}\text { VISCAL } \\
\text { ETIMATE } \\
\text { OF DAMAIE }\end{array}$ & TECHXIQLE:3 & RESTLTS \\
\hline $\begin{array}{l}\text { Vogelmann and } \\
\text { Rock } 1986\end{array}$ & NSOOI-TMS & $17 \mathrm{~m}$ & $89 / 1023$ & yes & no & Fe nevalles & $5 / 4$ & $R^{2}=1104$ \\
\hline Leckie et al. 1992 & MEIS II & $40 \mathrm{~cm}$ & S5/hree & yes & yes & $\begin{array}{l}\text { d. foititinen } \\
\text { to nearest } \\
5 \text { percent }\end{array}$ & $\begin{array}{l}15 \text { ratios } \\
4 \text { pc's } \\
\text { orig. bands }\end{array}$ & $\begin{array}{l}R^{2}=0112 \\
(I R / \text { rexi) }\end{array}$ \\
\hline Hermann et al. 1988 & $\begin{array}{l}\text { Dacdulus } \\
\text { ATM }\end{array}$ & $6 \mathrm{~m}$ & NR & NR & yes & $\begin{array}{l}\text { heavy chlorosis } \\
\text { neadle loss } \\
\text { damage percent } \\
\text { foliar loss }\end{array}$ & $\begin{array}{l}\text { spoctral } \\
\text { assessment }\end{array}$ & $\begin{array}{l}\text { general trends } \\
\text { reporied }\end{array}$ \\
\hline Vogelmann 1990 & Landsat $\mathrm{TM}$ & $30 \mathrm{~m}$ & NR & yes & $\begin{array}{l}\text { Landsat } \\
\text { pictures }\end{array}$ & $\begin{array}{l}\text { percent foliar } \\
\text { loss }\end{array}$ & $S / 4$ & $R^{2}=0.82$ \\
\hline $\begin{array}{l}\text { Vogelmann and } \\
\text { Rock } 1980\end{array}$ & Landsat TM & $30 \mathrm{~m}$ & 7 to 45 & yes & $\begin{array}{l}\text { Landisat } \\
\text { pictures }\end{array}$ & $\begin{array}{l}\text { percent foliar } \\
\text { loss }\end{array}$ & $\begin{array}{l}5 / 4 \\
7 / 4\end{array}$ & $\begin{array}{l}R^{2}=0.94 \\
R^{2}=0.84\end{array}$ \\
\hline $\begin{array}{l}\text { Vogelmann and } \\
\text { Rock } 1990\end{array}$ & Landsat TM & $30 \mathrm{~m}$ & & yes & $\begin{array}{l}\text { Landsat } \\
\text { picture } \\
\text { ecrial }\end{array}$ & $\begin{array}{l}\text { defoluatici vs } \\
\text { non-4hefoitated }\end{array}$ & $\begin{array}{c}5 / 4 \\
3 \\
4\end{array}$ & $\begin{array}{l}\text { significant } \\
\text { difference between } \\
198 \text { and } 1988 \\
\text { difference umages }\end{array}$ \\
\hline Ekstrund 1989 & Landsal TM & $30 \mathrm{~m}$ & $10 \mathrm{k} 12$ & yes & yes & $\begin{array}{l}\text { percont foritar } \\
\text { lows }\end{array}$ & $\begin{array}{c}1+3 \\
1 / 4 \\
4 / 2+4+7\end{array}$ & $\begin{array}{l}r=0 . \times 6) \\
r=0.76 \\
r=0.76\end{array}$ \\
\hline
\end{tabular}

1 = number of pixels covering sample or site; for Leckie et al. 1992 there were up wo 55 pixels

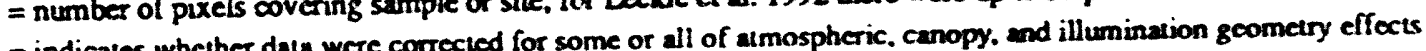

3 = numbers are for bands used to assess spectral deloction of damage classes 
on delection of wavelength positional shifts between stress and control samples/sites. Collins et al. (1978) noted that blue shifts in the red edge inflection point $\left(\lambda_{t e}\right)$ should also be evident as depressed NIR/red ratios. This is imtuitive when examining the red edge feature as presented in Pigure 1.3. Blue shifts can cause increases in reflectance in the red absorption region. Increases in reflectance in the red absorption region would depress the magnitude of NIR/red ratios. Ilow much of a blue shift is required before depressed NIR/red ratios can be delected, and what are the minimum spatial and spectral resolutions needed to connect a wavelength shift to a depressed NIR/red ratio are areas of active research. Developing more fully the connection between ratio techniques and wavelength shifts represents one approach to linking the detection to mapping of vegetation stress with more widely available low resolution sensing data.

As noted carlier, ratio eechniques were developed primarily for application to spectral data acequired from sattellite platforms. Applying ratio lechnigues, particularly combinations of red or visible and infrared, in arid enviromments has shown limited success in detecting vegetation stress (Tueller, 1987). Vegetation in arid regions usually comprises less than 30 percent of the ground cover, with the vegetation structure presenting small keaf area (e.g., vertically oriented and microphyllous leaves) for aerial and satellite measurements. Thus, the lack of greenness presented to the satellite or other vertically oriented remote sensing instrument hinders the ability of NIR/red ratios to distinguish subtle changes in vegetation.

The perpendicular vegetation index (PVI) (Richardson and Wiegand, 1977) and the other vegetation indices presented in Table 4-1 have attempted to remove the influence of soil for application in arid environments (e.g., Huete, 1988). Since the relationship between red edge shifts and the more sophisticated ratio techniques developed for use in arid environments has not yet been established, application of remote sensing in arid environments would favor the use of red edge shift techniques, especially as Horler et al. (1983) and Miller et al. (1990) have shown that the red edge position is not sensitive to mixed pixel problems.

\section{Moisture Stress Detection}

Gates el al. (1965), Allen and Richardson (1968), and Knipling (1970) have established that the decrease in plant reflectance beyond 1,300 $\mathrm{nm}$ (see Figure 1.3) is the result of water absorption. Tucker (1980) developed a stochastic model relating changing leaf spectral reflectance to changing leaf water content, and concluded that the 1,550 to $1,750 \mathrm{~nm}$ region was best suited for monitoring plant canopy water status. This conclusion no doubt contributed to the positioning of 1 andsat TM band 5 at this region of the EM spectrum.

Still, there have been relatively few investigations utilizing this spectral region to detect moisture stress. Using a hand-held radiometer (configured to replicate TM bands 3 (630 to 690 $\mathrm{nm}), 4(760$ to $900 \mathrm{~nm})$, and $5(1,550$ to $1,750 \mathrm{~nm}))$ placed slighily more that three inches above a salt marsh canopy, Hardisky et al. (1983) demonstrated that an infrared index (4-5/4+5) successfully detected decreasing soil moisture content as a result of increasing salinity. Hunt et al. (1983) developed an equation to determine relative water content (RWC): 


$$
L W C l=\frac{-\log [1-(T M 4-T M 5)]}{-\log \left[1-\left(T M 4_{F r}-T M 5_{F T}\right)\right]}
$$

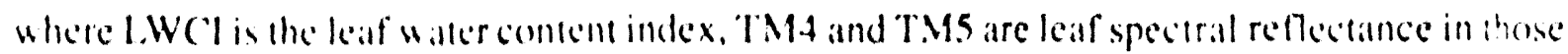
channels, and TM4Fr and TMSFr are the leaf spectral reflectance at full burgor (the amount of water in a lear when it can hold no more). The atuthors showed that L.WVCl is effectively identical to RWC, which is measured as the ratio of the difference berween fresh weight (FW) and dry weight (DW) divided by the difference between saturated or full turgor weight (SW) minus dry weight times 100 (e.g., ((FW DW $) /($ SW DW) * 100)).

The principal limitation with moisture stress detection is that it requires ground sampling to determine spectral reflectance at a known RWC. Ambrosia et al. (1991) found mixed results in defecting moisture stress in ponderosa pine stands (Pinus ponderosa) wing a 1.11 like $5 / 4$ r.tlo. The authors did not indicate that prior ground sampling of water status in the respective a:ands was done. Furthermore, the equation developed by llunt et al. (1983) is specific to leaf waller status (i.e., LWCI). At a minimum, watter status would have to be sampled throughout the entire canopy (both vertically and horizontally). The cost associated with such a sampling effort is presently prohibitive for regional applications of this technique.

Finally, it should also be noted that NIR/red ratios have been applied to detect moisture stress indirectly. As part of the large Area Crop Inventory (LACIE) undertaken by the USDA in the 1970s, Thompson and Wehmanen (1979) developed a Greenness Index Number (GIN) using Landsat MSS data. GIN was used to monitor the vigor of large agricultural fields devoted to wheat cultivation in the Great Plains. Tucker (1980) stated that GIN is an indirect measure of moisture stress, based on the assumption that moisture stress will retard plant development, resulting in lower overall chlorophyll concentrations. Landsat MSS data do not contain spectial measurements in the water absorption region (beyond 1,300 $\mathrm{nm}$ ).

\section{Summary and Conclusions}

Studies utilizing ratio techniques to map forest decline were examined specifically to compare critical aspects of these studies with those using higher resolution data and red edge shift techniques (discussed in Chapter 2). The principal difference found in comparing these studies is the magnitude of detectable stress. The forest decline studies were successful in quantifying stress as percent foliar loss with instruments of low spectral resolution on a regional scale. The magnitude of stress present in these studies was much greater than those discussed in Chapter 2. It is clear that extensive vegetation injury due to extreme contamination may be mapped using ratio techniques with low resolution instrumentation, while areas of lower contamination may require high resolution instruments and more complex methods of analysis for successful delection of associated stress.

The natural connection between wavelength shift and ratio techniques shows that blue shifts in the red edge can be evident as depressed NIR/red ratios, although simple ratio techniques (e.g., NIR/red) may have limited application in arid environments because of their 
sparse vegetation. Detection of moisture stress using spectral data beyond 1,300 nm was also discussed. While the spectral absorption feature of plants at wavelengths between 1,300 and $2,5(1) \mathrm{nm}$ has long been resognized, it has seen little regional application due partly to the prohibitive cost of collecting the necessary ground data.

Finally, many of the techniques discussed have been developed in response to the limitations, characteristics, and availability of remote sensing data. This would suggest that many more techniques will become available for the application of vegetation stress detection and mapping as improvements in instrumentation occur and associated data become available. 


\section{S.0 RESULTS OF SACRAMENTO RIVER STUDY}

As previously stited, DRI is examining remote sensing techniques useful in the detection of vegelation stress associated with contamination. During this revien precess. DRI - at the opportunity to apply some of these techniques at a surrogate location for DOE, follo ing a contamination event along the Sacramento River in northern Cillifomia.

DRI researchers contacted the California Deparment of Fish and Game (CDFG) to offer a research program designed to determine if the spectral response of vegetation could be used to identify and separate areas affected by the contamination from areas unaffected in conjunction with CDFG's existing efforts. CDFG personnel were already performing qualitative observations as part of a damage assessment plan required under two federal laws, the Comprehensive Environmental Response, Compensation and L iabilis! Act (C)RCLA, wh the Federal Wiater Pollution Control Act, commonly known as the Clean Water Act. Win the acquisition of a recently developed field portable, high resolution spectroradiometer, DRI made an initial investigation on July 26, 1991. Upon examination of the data, it was decided tha: a more thorough investigation deserved merit and researchers returned on August 13, 1991. Numerous vegetation reflectance spectra were collected along with observational data provided by CDFG. Logistical support from CDFG personnel was critical in obtaining these measurements. The results of applying remote sensing techniques to detect stressed vegetation resulting from contamination along the Sacramento River are presented below.

\section{Background}

On July 14, 1991, several train cars from a Southern Pacific train derailed along a section of track known as the "Cantara loop" just north of the town of Dunsmuir, California. The loop is located directly over the Sacramento River approximately 36 miles upstream from its inlet to Shasta Reservoir. One of the derailed train cars was carrying the chemical sodium methyldithiocarbamate (metam sodium), and leaked approximately 19,000 gallons of its contents into the Sacramento River. Upon mixing with the river water, metam sodium, a pesticide used to control soil fungi, bacteria, insects, and unwanted vascular plants, began to break down into several toxic compounds, including methylisothiocyanate (MITC) and hydrogen sulfide. Some of the breakdown products remained in the river as a visible plume, while others were volatilized into the atmosphere. Over the next few days, the plume was observed to travel downstream approximately 36 miles until slowing in the upper reaches of Shasta Reservoir. Damage to animal and plant life in and along the river was evident after the spill.

\section{Methodology}

Officials at the CDFG had selected numerous sites for vegctation transects where visual observations were recorded, along with the collection of plant tissue for herbarium samples and chemical analysis of MITC. For the purposes of the study, six species were chosen as sentinel 
species and selected for spectral analysis. With the spill site located approximately 36 river miles above Shasta Reservoir, termed river mile 36 (RM36), three transect sites were selected downstream at river mile 27 (RM27), river mile 7 (RM07) and rivermile I (RM01), and two sites upstream as control points located at river mile 37 (R.M37) and several miles further upstream above Box Canyon Dam along South Fork Creek (RMSF). As not all six species could be locitted at the two control sites, two additional sites were selected for control along tributaries downstream from the spill; one along Dog Creek (RMDC), and one along Soda Creek (RMSC). This allowed four of the six species to have two control sites, while two had just one control. The six sentinel species selected for observation are listed in Table 5-1 and their relative locations in Table 5-2.

TABLE 5-1: Sentinel species selected for observation and analysis along the Sacramento River.

\begin{tabular}{lcc}
\hline GENUS & COMMON NAME & ABBREVIATION \\
\hline Alnus rhombifolia & Alder & ALRH \\
Carex nudata & Sedge & CANU \\
Fraxinus latifolia & Ash & FRLA \\
Peltiphyllum peltatum & Indian Rhubarb & PEPE \\
Populus trichocarpa & Cottonwood & POTR \\
Salix melanopsis & Willow & SAME \\
\hline
\end{tabular}

TABLE 5-2: Location of measured species.

\begin{tabular}{lccc|cccc}
\hline & \multicolumn{3}{c|}{ AFFECTED SITES } & \multicolumn{4}{c}{ CONTROL SITES } \\
SPECIES & RM01 & RM07 & RM26 & RM37 & RMSF & RMDC & RMSC \\
\hline ALRH & $\mathrm{X}$ & $\mathrm{X}$ & $\mathrm{X}$ & $\mathrm{X}$ & $\mathrm{X}$ & & \\
CANU & $\mathrm{X}$ & $\mathrm{X}$ & $\mathrm{X}$ & $\mathrm{X}$ & & & \\
FRLA & $\mathrm{X}$ & $\mathrm{X}$ & $\mathrm{X}$ & & & & $\mathrm{X}$ \\
PEPE & $\mathrm{X}$ & $\mathrm{X}$ & & $\mathrm{X}$ & & $\mathrm{X}$ & \\
POTR & $\mathrm{X}$ & & $\mathrm{X}$ & $\mathrm{X}$ & $\mathrm{X}$ & & \\
SAME & $\mathrm{X}$ & $\mathrm{X}$ & $\mathrm{X}$ & $\mathrm{X}$ & $\mathrm{X}$ & & \\
\hline
\end{tabular}

Leaf samples were collected from the identified species and arranged to cover an approximate 15-inch-diameter circle. Ten spectra were collected for each sample with a 25 degree field of view using an Analytical Spectral Devices, PS-II. The PS-II records information 
between $335 \mathrm{~nm}$ and $1,065 \mathrm{~nm}$ in 512 chainels averaging approximately $1.4 \mathrm{~nm}$ in width. This provided the basis for spectral analysis and statistical tests. All spectra were collected within one minute after calibrating the spectrometer against a spectralon white reference standard at integration times of either $175 \mathrm{~ms}$ or $350 \mathrm{~ms}$.

For this study, the position of the red edge was determined by calculating the first derivative of the individual spectral curves and having a computer program pick the maximum inflection point (MIP) on each first derivative curve (Figure 5.1). The associated wavelength of each MIP was averaged to determine the position of the red edge for each specimen at each location. First derivative curves were smoothed to eliminate the possibility of picking a MIP created by noise in the signal. The smoothing algorithm is that used by Milton et al. (1991), and was applied 10 times to each curve and is presented here:

$$
a^{\prime}(i)=\frac{a(i-1)+2 a(i)+a(i+1)}{4}
$$

The first derivative calculation and smoothing operation was applied to each spectral curve between 400 and $800 \mathrm{~nm}$. Student's t-tests were applied between each set of 10 MIP values for each species at each site to determine the significance of relative differences between calculated red edge positions. All red edge positions compared were statistically significantly different $(P<0.001)$ unless otherwise stated. (If $P<0.001$, the likelihood that these are chance variations is less than 0.1 percent.)

\section{Complications}

It should be noted that unlike laboratory studies, many factors such as homogeneous sample availability for both control and affected species, uniform dose exposure, and a constant energy flux were uncontrollable; however, since that is the environment to which these techniques would be applied, it was a suitable environment for real world applications. Further confounding this study were observations that one or more of the toxic byproducts of the contaminant metam sodium was in a gaseous state that allowed both air currents and river hydraulics to play a role in the potential exposure at the leaf and root level, respectively. In fact, wind measurements supported observations of toxic gas moving upstream past one of the control sites at RM37. At several locations immediately upstream from trestles, large pockets of extensive injury to vegetation were observed. These areas are believed to be the result of the trestle shielding canyon winds, allowing a greater exposure dose and duration. This arifact became known as the "trestle effect." However, even with these complexities, it was hypothesized that due to contaminant-induced stress, the red edge might be observed to shift from the longest wavelengths at control sites to the shortest wavelengths immediately downstream of the spill site, with the red edge refurning towards control site positions as one moved farther away from the spill site. This shift towards shorter wavelengths, or blue shift, would be consistent with the majority observations associated with stressed vegetation recorded in the literature. 


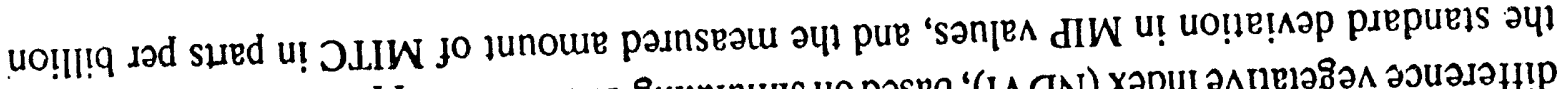

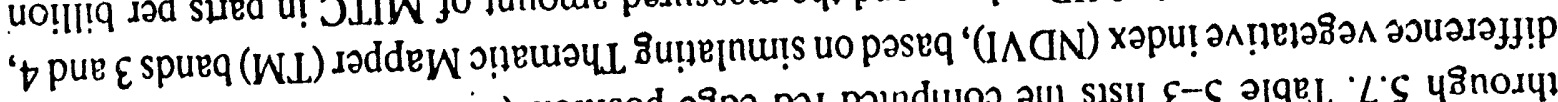

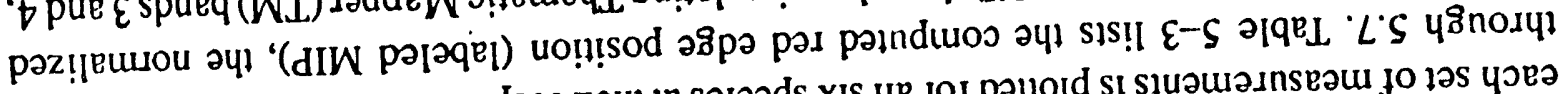

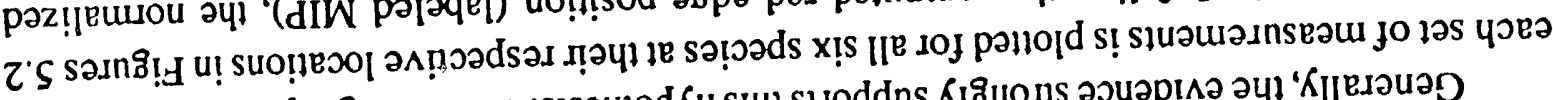

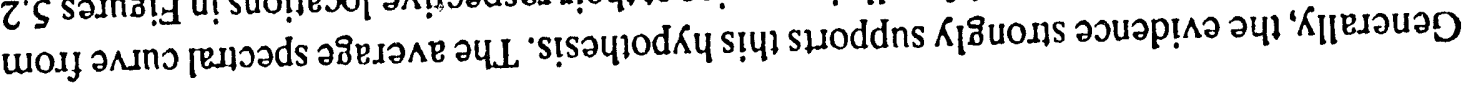

syinsay

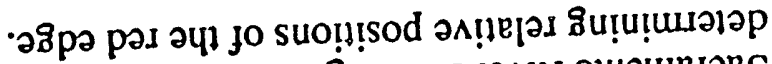
Ioj lu!

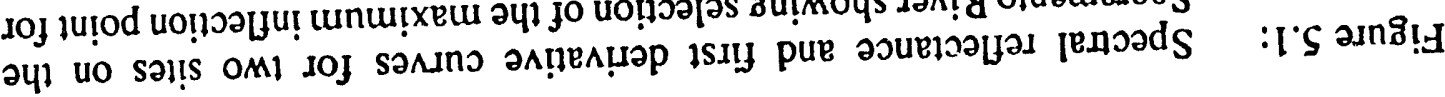

บ|бนә|әАอМ

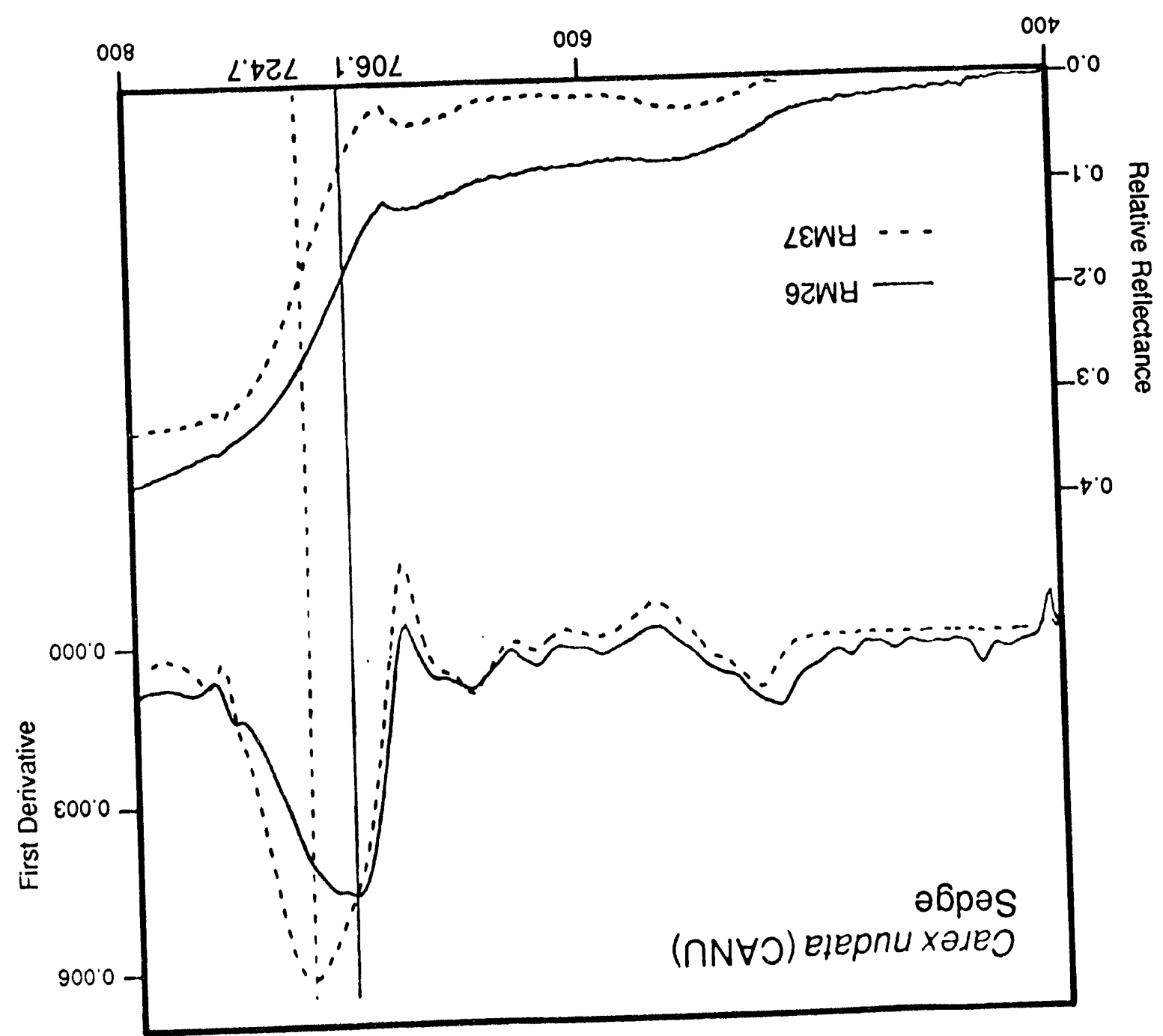




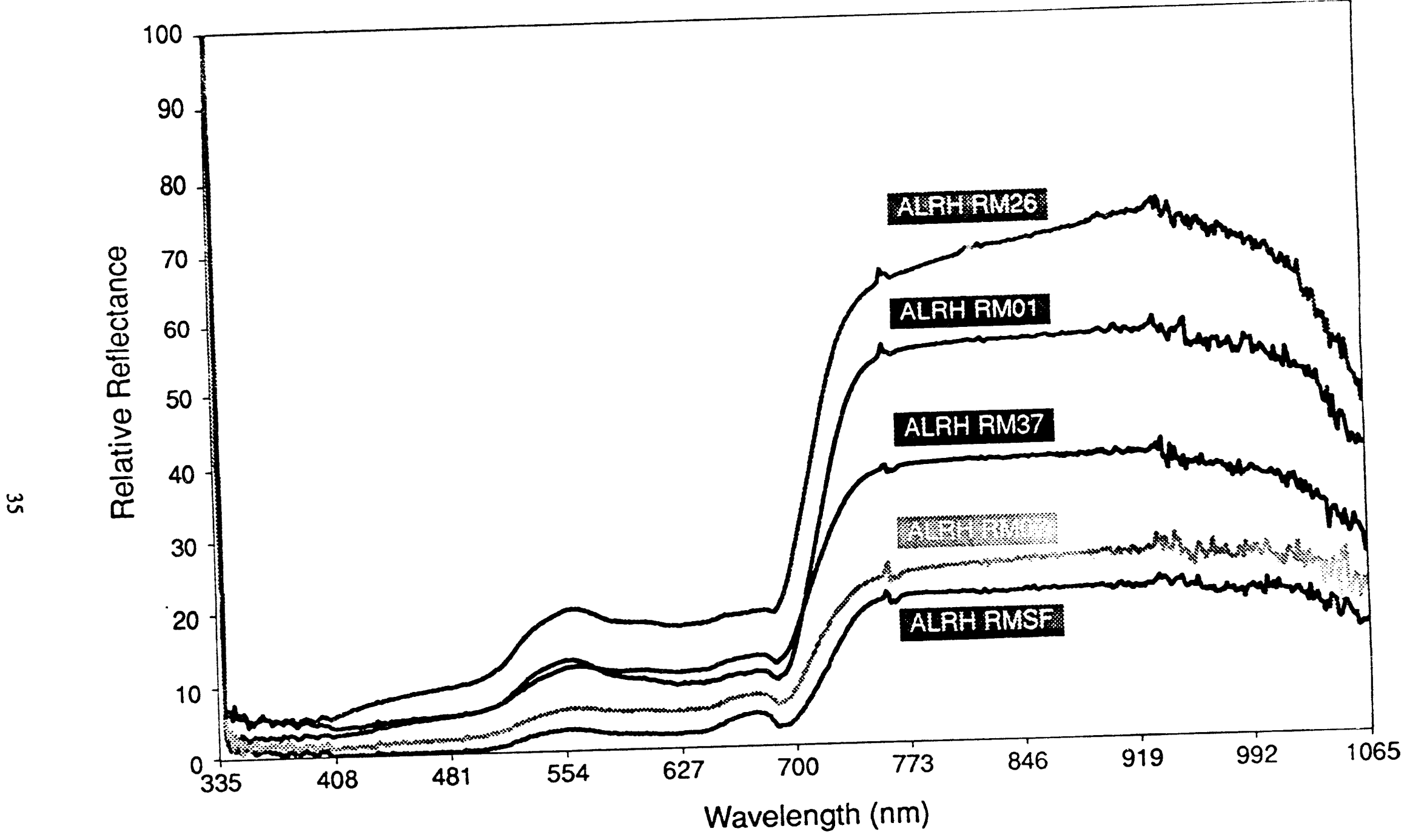

Figure 5.2: Average spectral reflectance curves of Alnus rhombifolia (ALRH) at sclected sampling sites along the Sacramento drainage, 8/13/91. 


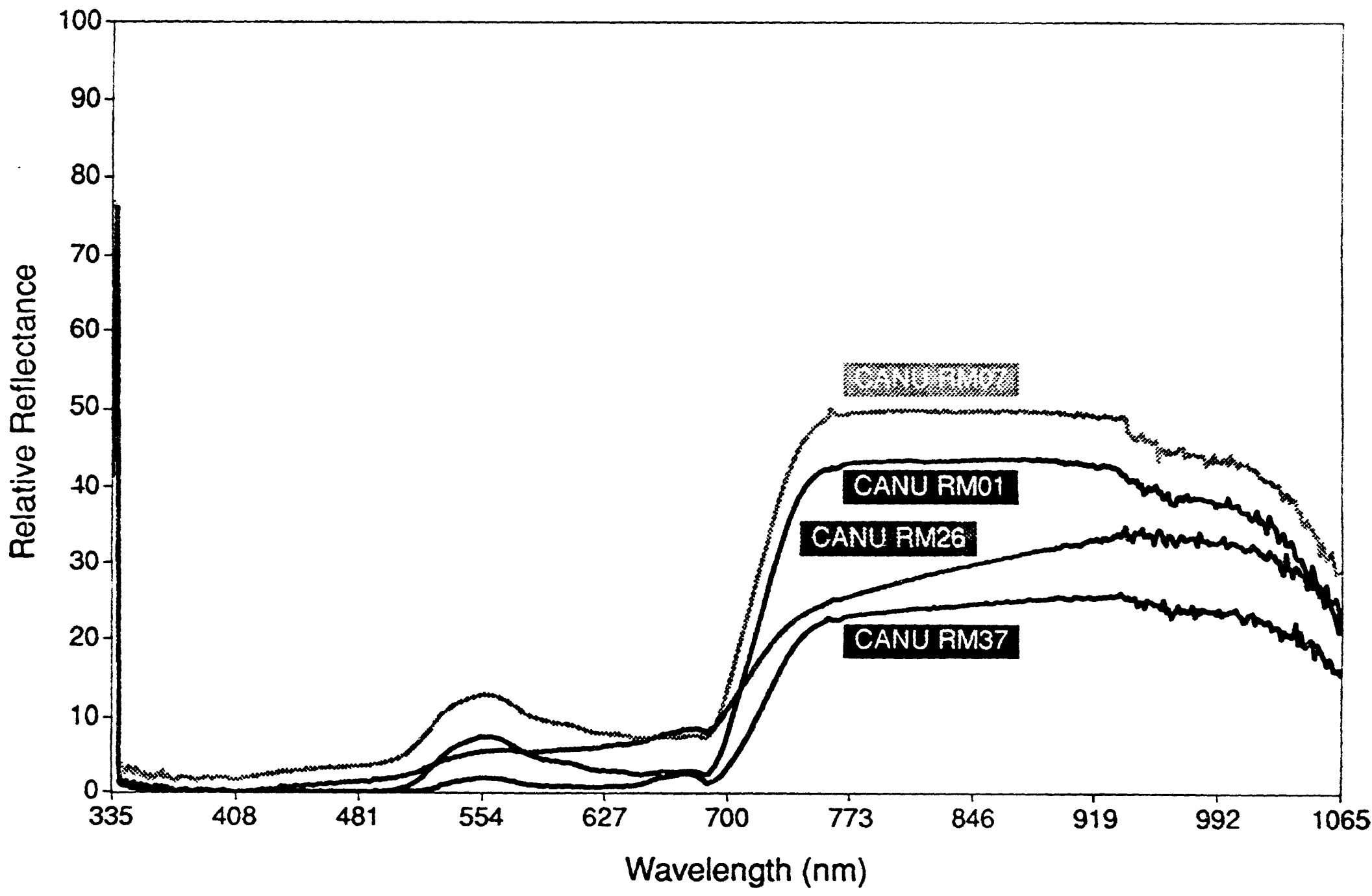

Figure 5.3: Average spectral reflectance curves of Carex nudata (CANU) at selected sampling sites along the Sacramento drainage, $8 / 13 / 91$. 


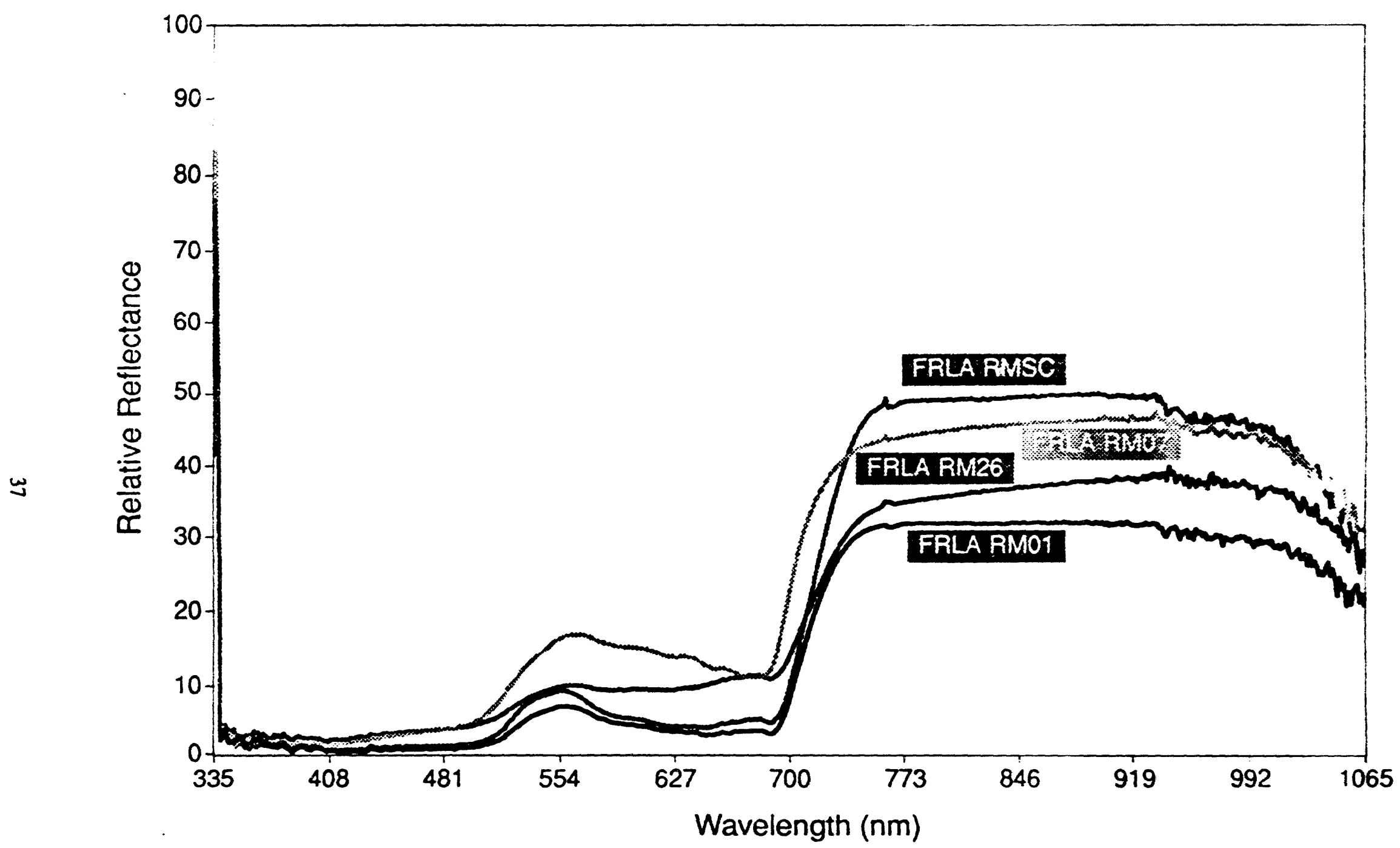

Figure 5.4: Average spectral reflectance curves of Fraxinus latifolia (FRLA) at selected sampling sites along Sacramento drainage, 8/13/91. 


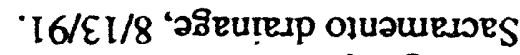

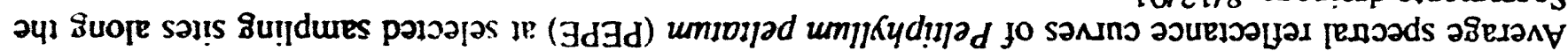

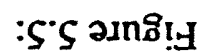

(uu) чฉбиәрлем

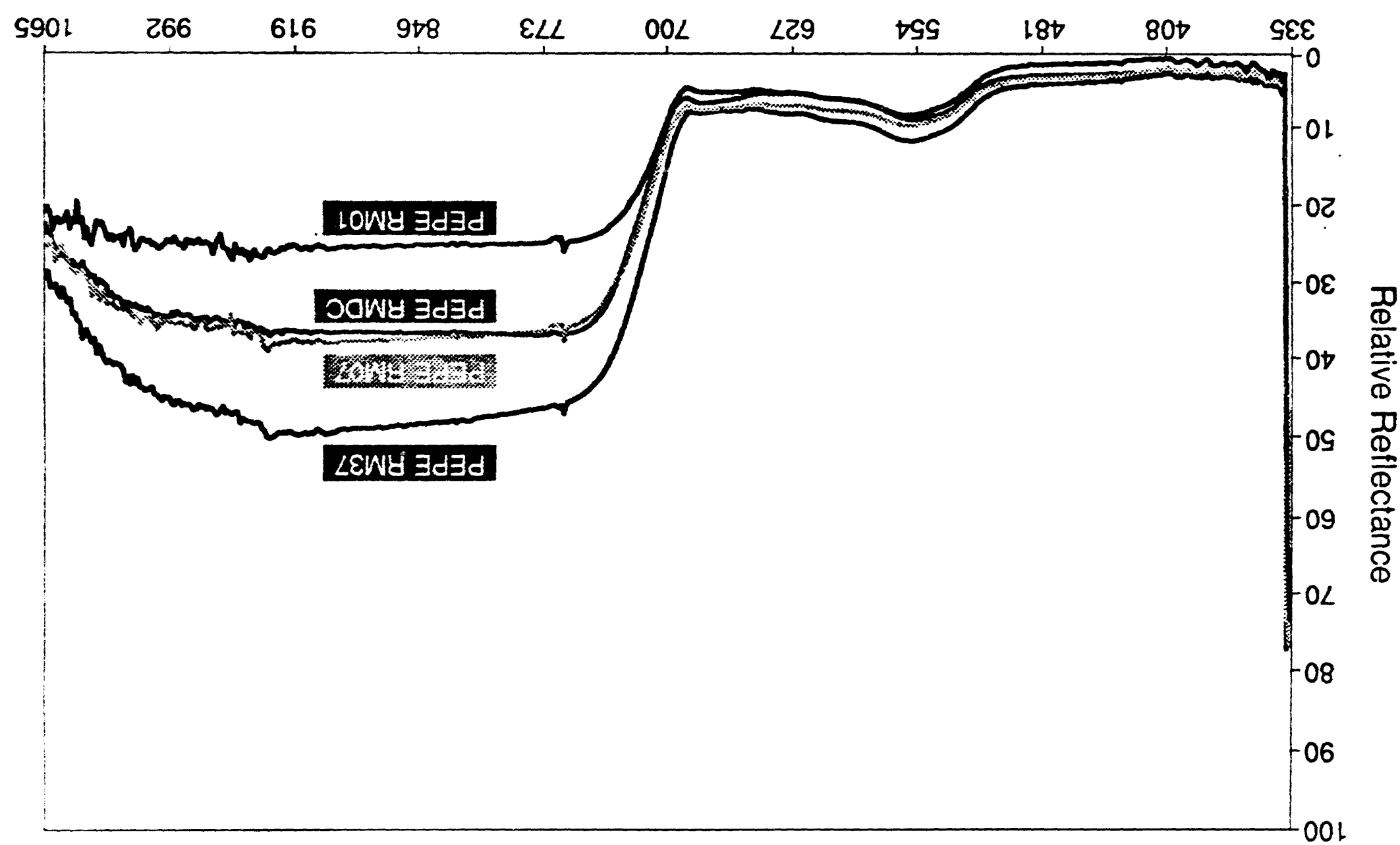




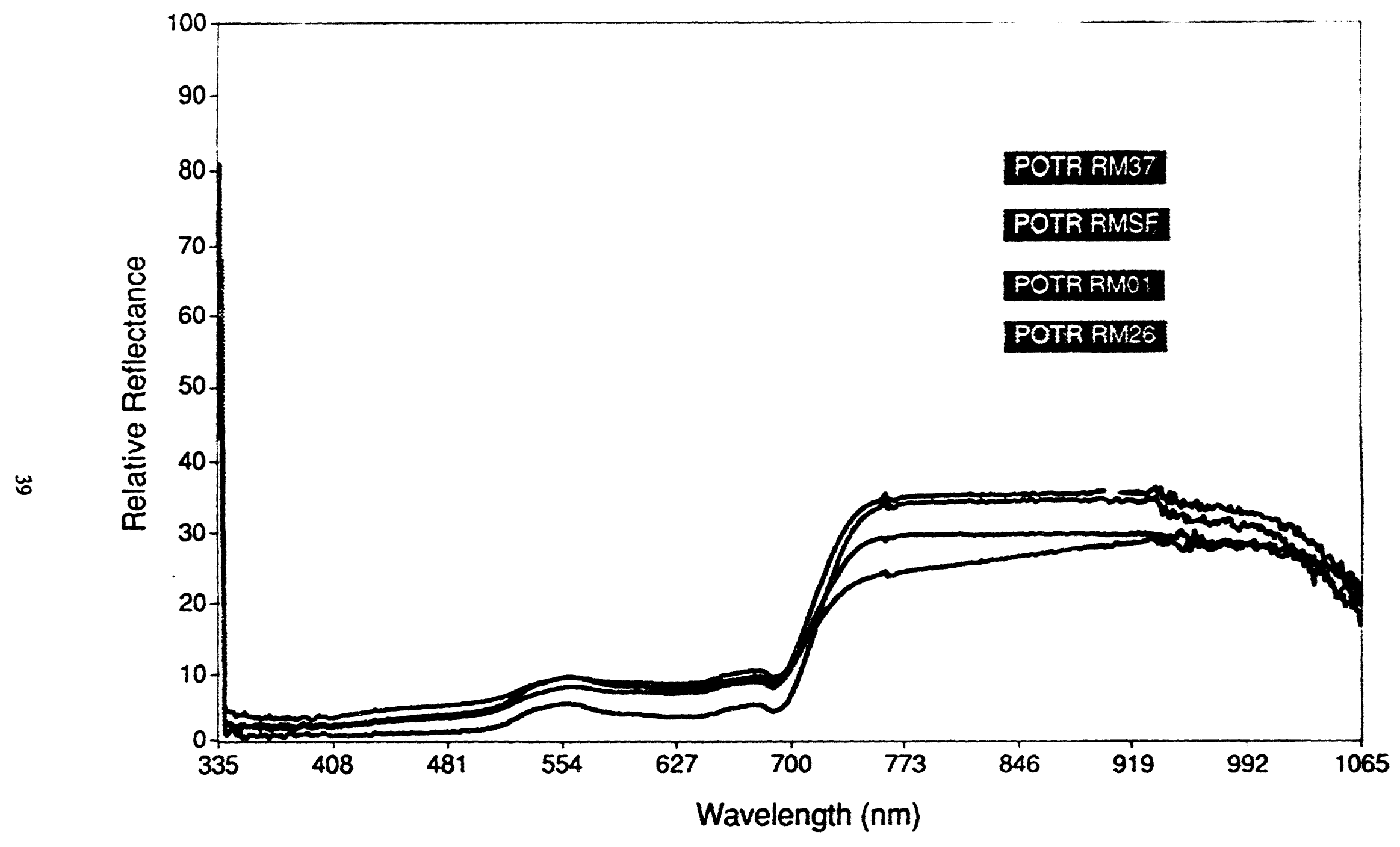

Figure 5.6: Average spectral reflectance curves of Populus trichocarpa (POTR) at selected sampling sites along the Sacramento drainage. $8 / 13 / 91$. 


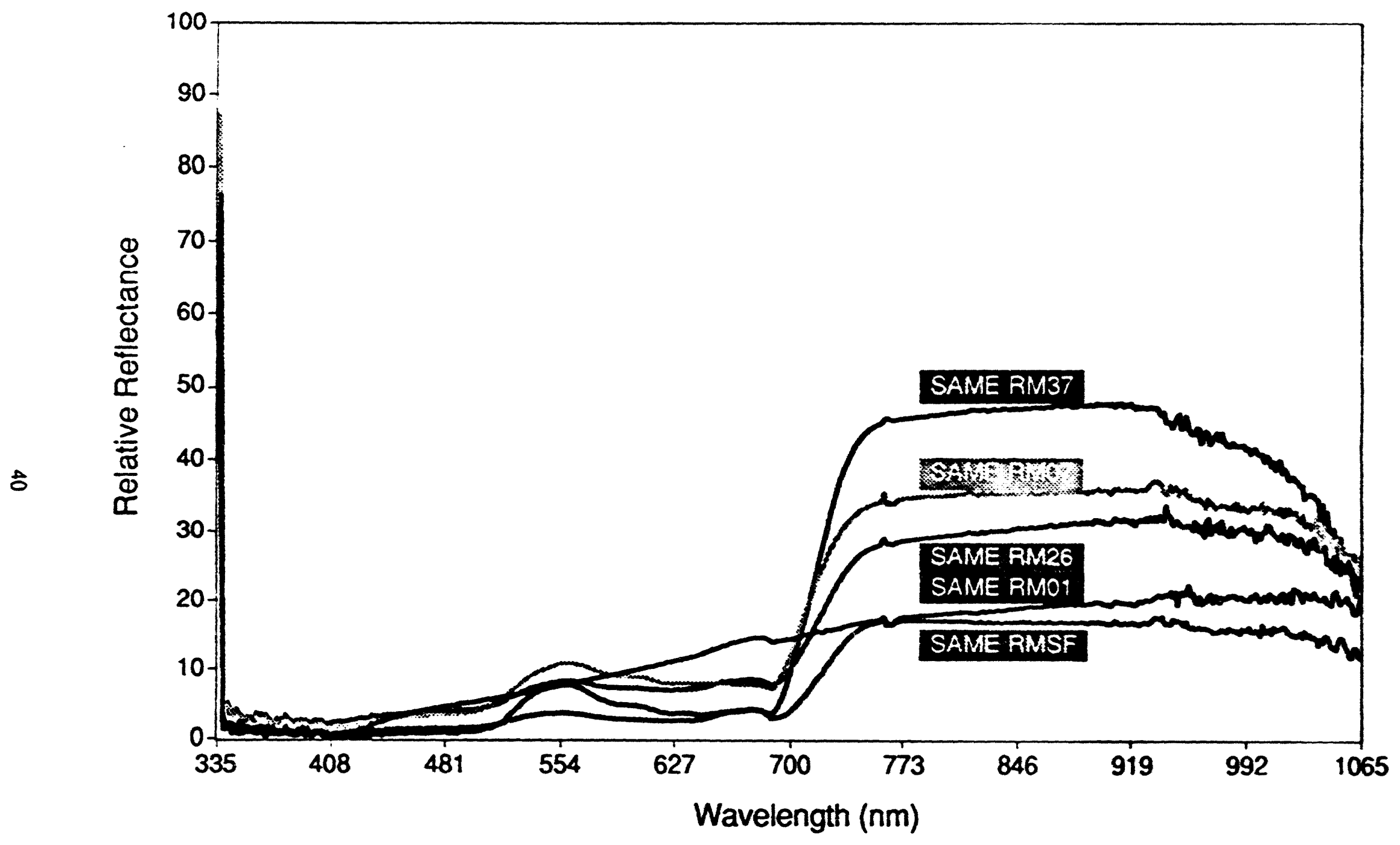

Figure 5.7: Average spectral reflectance curves of Salix melanopsis (SAME) at selected sampling sites along the Sacramento drainage, 8/13/91. 
TABLE 5-3: Results of analyses conducted for the Sacramento River study.

\begin{tabular}{|c|c|c|c|c|c|}
\hline & location & $\begin{array}{l}\text { Maximum } \\
\text { Inflection } \\
\text { Point (MIP) }\end{array}$ & $\begin{array}{l}\text { Standard } \\
\text { Deviation }\end{array}$ & NDVI & $\begin{array}{l}\text { L.aboratory } \\
\text { Results } \\
\text { ppo of Mlic }\end{array}$ \\
\hline $\begin{array}{l}\text { AlRII } \\
\text { Alder- } \\
\text { Almus rhombifolia }\end{array}$ & $\begin{array}{l}\text { RMSF } \\
\text { RM } 37 \\
\text { RM26 } \\
\text { RM07 } \\
\text { RM01 }\end{array}$ & $\begin{array}{l}722.6 \\
709.3 \\
707.9 \\
709.4 \\
715.4\end{array}$ & $\begin{array}{l}0.791 \\
0.917 \\
3.935 \\
0.945 \\
0.738\end{array}$ & $\begin{array}{l}0.772 \\
0.522 \\
0.521 \\
0.618 \\
0.750\end{array}$ & $\begin{array}{r}5 \\
0 \\
11 \\
0 \\
11\end{array}$ \\
\hline $\begin{array}{l}\text { CANU } \\
\text { Sedge- } \\
\text { Carex mudana }\end{array}$ & $\begin{array}{l}R M 37 \\
R M 26 \\
R M 07 \\
R M 01\end{array}$ & $\begin{array}{l}724.8 \\
706.4 \\
714.2 \\
719.9\end{array}$ & $\begin{array}{l}1.226 \\
2.018 \\
4.044 \\
0.676\end{array}$ & $\begin{array}{l}0.944 \\
0.626 \\
0.741 \\
0.864\end{array}$ & $\begin{array}{r}6 \\
1.377 \\
2.33 \\
77\end{array}$ \\
\hline $\begin{array}{l}\text { FRLA } \\
\text { Ash- } \\
\text { Fraximus latifolia }\end{array}$ & $\begin{array}{l}\text { RMSC } \\
\text { RM26 } \\
\text { RM07 } \\
\text { RM01 }\end{array}$ & $\begin{array}{l}715.0 \\
712.7 \\
699.0 \\
705.0\end{array}$ & $\begin{array}{l}1.538 \\
4.120 \\
0 \\
0.590\end{array}$ & $\begin{array}{l}0.845 \\
0.339 \\
0.569 \\
0.823\end{array}$ & $\begin{array}{r}0 \\
0 \\
105 \\
0\end{array}$ \\
\hline $\begin{array}{l}\text { PEPE } \\
\text { Indian rhubarab- } \\
\text { Pettiphyllum pelianum }\end{array}$ & $\begin{array}{l}\text { RMDC } \\
\text { RM37 } \\
\text { RM07 } \\
\text { RM01 }\end{array}$ & $\begin{array}{l}711.7 \\
705.0 \\
708.7 \\
704.3\end{array}$ & $\begin{array}{l}0.612 \\
0.590 \\
1.104 \\
0.676\end{array}$ & $\begin{array}{l}0.744 \\
0.746 \\
0.685 \\
0.667\end{array}$ & $\begin{array}{r}0 \\
0 \\
53 \\
0\end{array}$ \\
\hline $\begin{array}{l}\text { POTR } \\
\text { Cottonwood-- } \\
\text { Populus trichocarpa }\end{array}$ & $\begin{array}{l}\text { RMSF } \\
\text { RM37 } \\
\text { RM26 } \\
\text { RM01 }\end{array}$ & $\begin{array}{l}718.6 \\
714.1 \\
705.7 \\
712.3\end{array}$ & $\begin{array}{l}0.676 \\
0.979 \\
0.676 \\
0.945\end{array}$ & $\begin{array}{l}0.758 \\
0.621 \\
0.557 \\
0.658\end{array}$ & $\begin{array}{r}0 \\
12 \\
116 \\
35\end{array}$ \\
\hline $\begin{array}{l}\text { SAME } \\
\text { Willow- } \\
\text { Salix melanopsis }\end{array}$ & $\begin{array}{l}\text { RMSF } \\
\text { RM37 } \\
\text { RM26 } \\
\text { RM07 } \\
\text { RM01 }\end{array}$ & $\begin{array}{l}724.4 \\
716.6 \\
718.3 \\
706.1 \\
608.0\end{array}$ & $\begin{array}{c}0.590 \\
0.725 \\
1.933 \\
0 \\
129.756\end{array}$ & $\begin{array}{l}0.571 \\
0.849 \\
0.647 \\
0.638 \\
0.218\end{array}$ & $\begin{array}{r}0 \\
0 \\
55 \\
0 \\
174\end{array}$ \\
\hline
\end{tabular}

*detection limit of instrument is 5 to $10 \mathrm{ppb}$ 
(ppb) in each respective sample. MITC levels were determined using gas chromatography with a nitrogen-phosphorus detector with 5 to $10 \mathrm{ppb}$ being the approximate detection limit of the insurument.

For all six species, the red edge position or MIP is at a maximum wivelength al one or both of the control sites (Table 5-3). For three of the five species located at RM26 (the closest site downstream of the spill site), the MIP has shifted to its measured minimum, averaging a shift of over $15 \mathrm{~nm}$ from the maximum control MIPs. The other two species display minimum MIPs at R.M07, where the shift is 16.0 and $18.3 \mathrm{~mm}$ for ash and willow, respectively. RMO)7 is localed jus upstream from a train trestle which may be a contributing factor to the observed shifts. This also suggests the importance of specific plant locations within a site due to river and air current dymamies and heir role in providing contact with the contaminant. These statements exclude the the calculated .MIP of $608 \mathrm{~nm}$ for sample SA.ME at R.M(0), since no red edge is apparent in the averaged spectrum (Figure 5.7), and the specimen had died prior to spectral measurements. Significantly, all species at control site Ris137 display a blue shift in the red edge as compared to duplicate controls, lending support to observations of gaseous byproducts moving upstreanm from the spill site at RM36 past RM 37. This helps to explain the three instances where RM.37 MIP values are not greater than all corresponding species downstream.

Two of the species, coltonwood and sedge, show unusually high correspondence at a number of levels. As scen in Table 5-3, coltonwood displays a shift from $718.6 \mathrm{~nm}$ at our "safe" control site RMSF, to $714.1 \mathrm{~nm}$ at RM37. Downstream of the spill, the red edge shifts to 705.7 nin at RM26 and then back up to $712.3 \mathrm{~nm}$ at RM01. These red edge positions are all significantly different with $p<0.001$. Sedge (Table 5-3) exhibits similar behavior with a red edge maximum position of $724.8 \mathrm{~nm}$ at RMSF, and a minimum of $706.4 \mathrm{~nm}$ at RM26. The red edge shifts back towards the control at $714.2 \mathrm{~nm}$ and $719.9 \mathrm{~nm}$ at RM07 and RM01 sites, respectively. NDVI values also correspond well as control sites have the highest NDVI values and RM26 the lowest. This behavior corresponds exactly with what might be expected considering the conditions of the event. Even more significant is the direct correspondence these two species display with respect to measured amounts of MITC (Table 5-3). Control site samples had zero or detection limit amounts of MIITC, while RM26 samples had the maximum recorded levels of $1377 \mathrm{ppb}$ and $116 \mathrm{ppb}$ for both species, sedge and coltonwood, respectively. Two other species, ash and willow, display a similar inverse relationship. At RM07, ash displays its minimum MIP value coincident with a measured value of MITC of $105 \mathrm{ppb}$, while the maximun MITC value in willow was 174 ppb, which was dead prior to the time of observation.

NDVI values generally behave proportionally to MIP values, and can draw attention to areas in the data where results of using the red edge technique are less clear. Its use clearly identifies the dead willow sample at RM01 and may help explain the seemingly inconsistent MIP values for willow at RM37 and RM26. NDVI values are computed by averaging the instrument response between 616 to 697 and 789 to $911 \mathrm{~nm}$ to simulate the response in channels 3 and 4 , respectively, of the broad band TM instrument. The band response is then used to calculate NDVI as presented below: 


$$
N D V I=\left(t m 4-t m^{3}\right) /\left(t m 4+t m^{3}\right)
$$

While averaging the response over the range covered by channels 3 and 4 deletes informattion contained in the tho areas, calculating NDVI is an accepted method of providing a parameter that helps quantify the vigor or health of vegetation (Richardson and Everitt, 1992). As NDVI is some what sensitive to the strength of the energy flux during meisurement, its use with high specitral resolution data may decrease as other techniques become available.

\section{Summary and Conclusions}

The evidence presented here strongly supports the hypothesis that shifts in the red edge of vegetation would occur due to stress caused by contamination and would correspond with distance from the spill site. While the mechanism of MITC uptake is not well understood, it appears that vegetation along the Sacramento River may have been exposed 10 toxins through contact at both the root and leaf level. Spectral measurements have provided a method of stress detection that corresponds extremely well with chemical analysis results of plant lissue. The fact that one-third of the species studied displays this correspondence in an uncontrolled field experiment lends great support for spectral applications at other contaminated sites. Furthemore, the spectral measurements seem to be sensitive enough to detect departures from normal even when toxin uptake does not occur. This has significant implications for many contaninants of concern at DOE sites, such as PCBs, that are typically bound in the soil and not incorporated into plant tissue. In addition, the magnitude of the observed shifts potentially allows for current airborne systems to detect these kind of spectral changes.

In retrospect, if this were a designed experiment, the greatest change in methodology would be for data collection efforts to have occurred prior to the spill. It is suspected this effort would further confirm the results and clarify any ambiguities in the data. This is significant in that it sets a precedent for DOE to obtain high resolution spectral data to establish baseline conditions specifically for monitoring and evaluating efforts undertaken during remediation activities. 



\subsection{PIIYSIOLOGICAL RESPONSE OF PLANTS TO STRESS 5}

The preceding chapters have discussed various remote sensing techniques used to detect vegetation steess, which has been linked to changes in chlorophyll. This chapter reviews three important phy siological functions that can all be affected by the presence of contimininants. The se three physiological functions (chlorophyl//chloroplast development, photosynthesis, and nutrient uptake) rely either directly or indirectly on the presence of chlorophyll. Each is reviewed below.

\section{Chlorophyll'Chloroplast Development}

In angiosperms (flowering plants), chlorophyll forms only in the presence of light. (Conifers and less structurally complex plants can form chlorophyll in the absence of light, although light stimulates the process.) It has been shown that chlorophyll concentrations increase tenfold in spinach leaves as they grow from immaturity to full size. The light-stimulated chemical reactions use a precursor chlorophyll molecule, protochlorophyllide $a$, to form chlorophyll $a$, which is then used to form chlorophyll $b$.

The series of light-stimulated reactions that result in the formation of chlorophyll is shown in Figure 6.1. While numerous chemical compounds are shown in this figure, the important

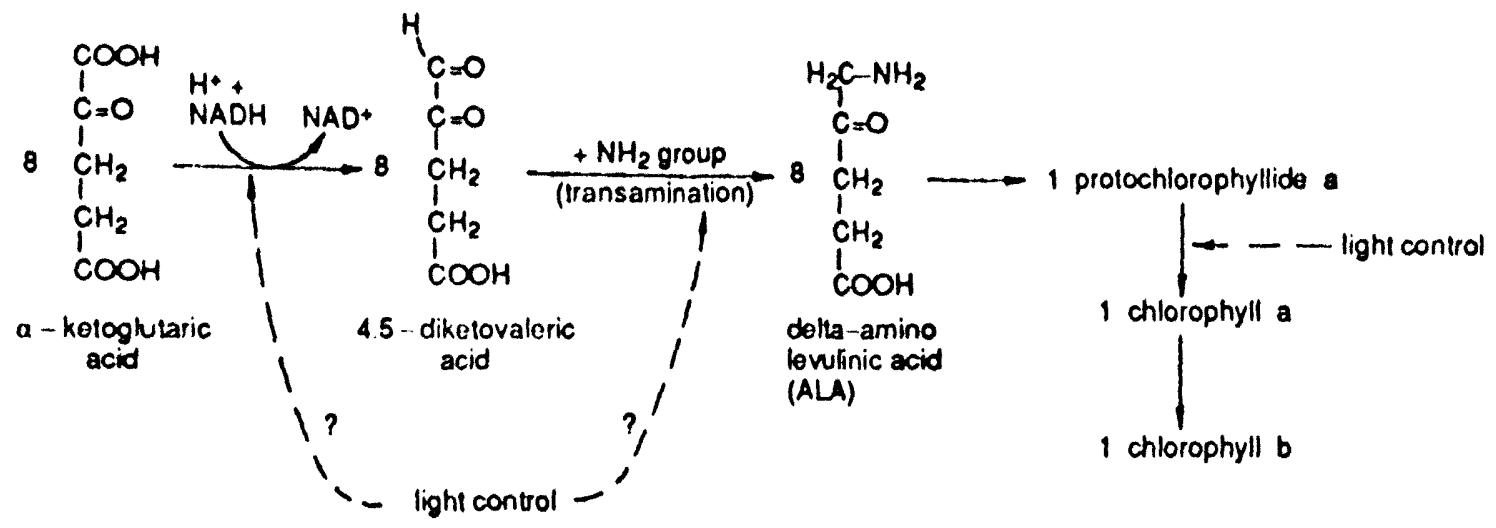

Figure 6.1: Light-stimulated reactions of chlorophyll synthesis (reproduced from Salisbury and Ross, 1979).

components to notice are NADH/NAD ${ }^{+}$(nicotinamide adenine dinucleotide, a chemical cousin of NADPH/NADP+ critical in photosynthesis) and the amino group $\mathrm{NH}_{2} . \mathrm{NH}_{2}$, the building block of proteins, is an essential component of NADH/NAD ${ }^{+}$, as is the phosphate compound $\mathrm{PO}_{4}{ }^{3-}$. These chemical compounds are highlighted because reduction in uptake of nitrogen (N),

${ }^{5}$ Adapted primarily from Salisbury and Ross (1979) and Rost et al. (1979). 
phosphorous $(\mathrm{P})$, iron $(\mathrm{Fe})$, and magnesium $(\mathrm{Mg})$ or interruption in the metabolism of any of these elements (for example, incorporation of $\mathrm{H}_{2} \mathrm{PO}_{4}{ }^{-}$into NADH/NAD ${ }^{+}$) can cause a reduction in chlorophyll concentration.

A second important characteristic of chlorophyll development is that it precedes and stimulates the development of the fine structures in the chloroplast organelle. 6 The basic structure of the chloroplast organelle is shown in Figure 6.2. The label $\mathrm{G}$ marks a granum, which

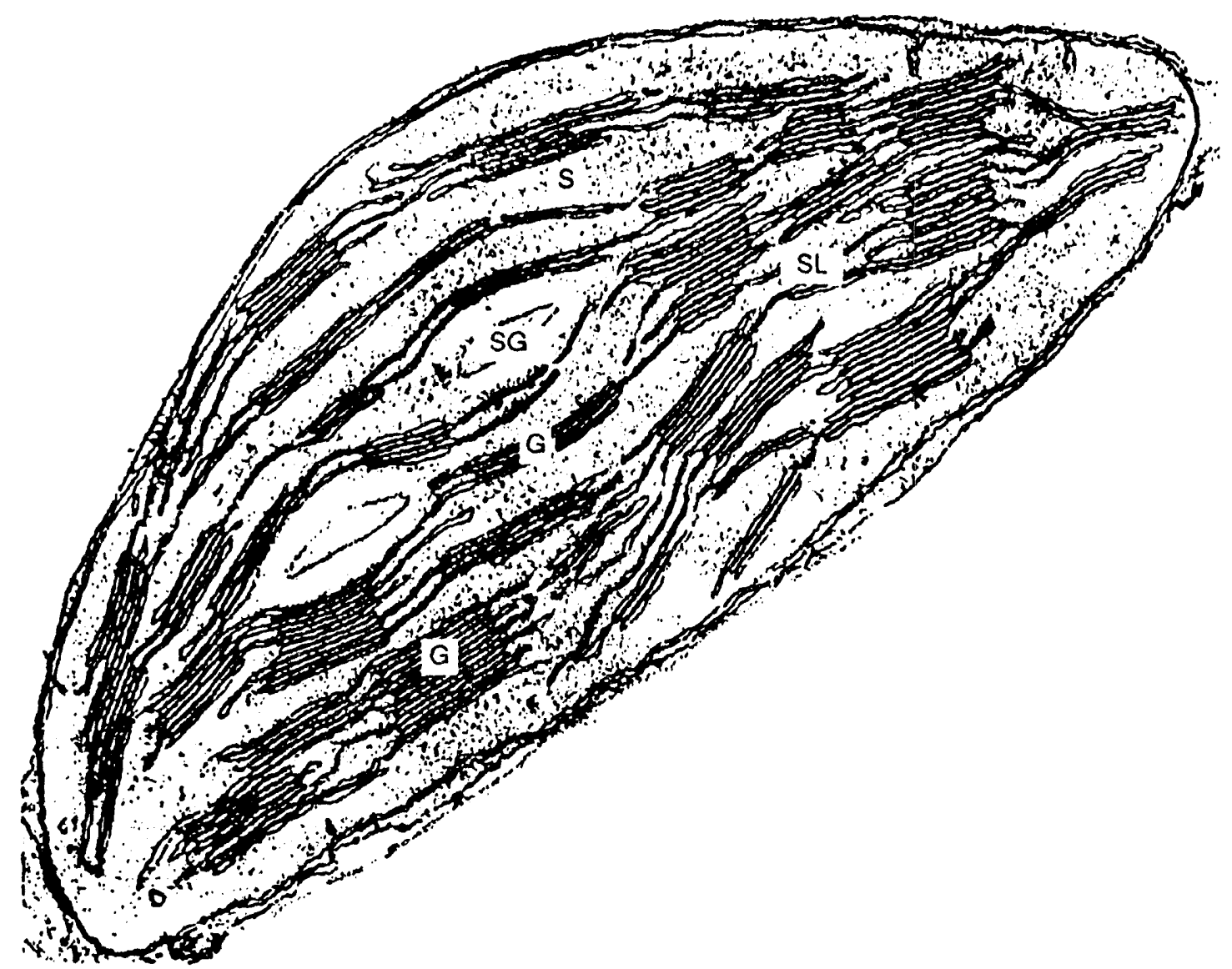

Figure 6.2: Anatomical structure of chloroplast organelle (reproduced from Salisbury and Ross, 1979).

is a stack of thylakoids. Thylakoids are "sacs" which contain chlorophyll, and are where many photosynthetic reactions take place. Individual granum $(G)$ stacks are sometimes connected by stroma lamellae (SL). The granum stacks and stroma lamellae are suspended in a colloidal matrix called the stroma (S). SG depicts a starch grain, the ultimate product of photosynthesis. Thus, physical structures may be changed by processes that affect chlorophyll development.

${ }^{6}$ An organelle is a membrane-bound spocial region within a cell in which particular functions are carried out. Photosynthesis is carried out in chloroplasts, and respiration is carried out in mitochondria. 


\section{Photosynthesis}

Photosynthesis is simplified and summarized by the equation below:

$$
\eta \mathrm{CO}_{2}+\mathrm{H}_{2} \mathrm{O}+\text { light } \rightarrow\left(\mathrm{CH}_{2} \mathrm{O}\right)_{\eta}+\eta \mathrm{O}_{2}
$$

The details of the reactions that this equation summarizes are complex; however, an attempt is made to present a clear and understandable review of photosynthesis using the following three diagrams.

Figure 6.3 shows how light absorbed by chlorophyll molecules is used to initiate a series of reactions that encompass photosynthesis. Upon absorbing light, chlorophyll molecules are converted from a stable or ground state to an excited state. Light accomplishes this by driving electrons away from the positively charged nucleus of a chlorophyll molecule a distance corresponding to the energy absorbed. ${ }^{7}$ The electronic energy of chlorophyll molecules is then transferred to an energy collection center, as shown in Figure 6.3 by the arcing arrows.

The "horizontal" energy transfer shown in Figure 6.3 is again represented in Figure 6.4 as the black lines that begin with a dot and end with an arrow. Figure 6.4 is read from bottom right to upper left. There are two energy collection centers, labeled P680 and P700. The transfer of electronic energy from chlorophyll molecules to P680 and P700 has been compared to a "bucket brigade." Each of the smaller circles in Figure 6.4 represents a chlorophyll molecule within the thylakoid.

After receiving energy from excited chlorophyll molecules, P680 is able to remove electrons from water, splitting it into $\mathrm{H}^{+}$and $\mathrm{OH}^{-}$. The electrons taken from water are then passed through a series of electron acceptors, and are eventually used to reduce $\mathrm{NADP}^{+}$to NADPH (top left-hand corner of Figure 6.4). Thus, water is critical in photosynthesis in that it provides a source of electrons necessary for electron transport reactions as well as the reduction of NADP+.

Figure 6.4 is commonly referred to as the $\mathrm{Z}$-scheme, and the series of reactions shown are known as the electron-transport or light reactions of photosynthesis. The rationale for presenting the $\mathrm{Z}$-scheme is to highlight the importance of several nutrients (e.g., manganese, $\mathrm{Mn}$; iron, Fe; Copper, $\mathrm{Cu}$ ) involved in photosynthesis.

Ultimately, the NADPH and ATP created by light reactions of photosynthesis are used to produce 6 -carbon carbohydrates. The production of these sugars in photosynthesis is referred to

${ }^{7}$ The five scts of five horizontal lines in Figure 6.3 represent the excited state of a chlorophyll molecule. In addition to being used for photosynthesis, the energy gained from light can be lost through release of heat or fluorescence (light production accompanying rapid decay of electronic energy). Blue light causcs the chlorophyll molccule to take on a higher energy state (an electron is driven further from the nucleus of the chlorophyll molecule) than red light. This happens because blue light is of a shorter wavelength than red light and therefore contains more energy (refer to Introduction). Ultraviolet (UV) light is of shorter wavelength than blue light (less than $\approx 400 \mathrm{~nm}$ ), containing even more energy. If UV light were absorbed by chlorophyll molecules, the heat produced through electronic decay would be potentially harmful to plants. Figure 6.3 shows why UV, IR, and visible light is referred to as "100 hot," "too cold," and "just right," respectively, in the Introduction. 


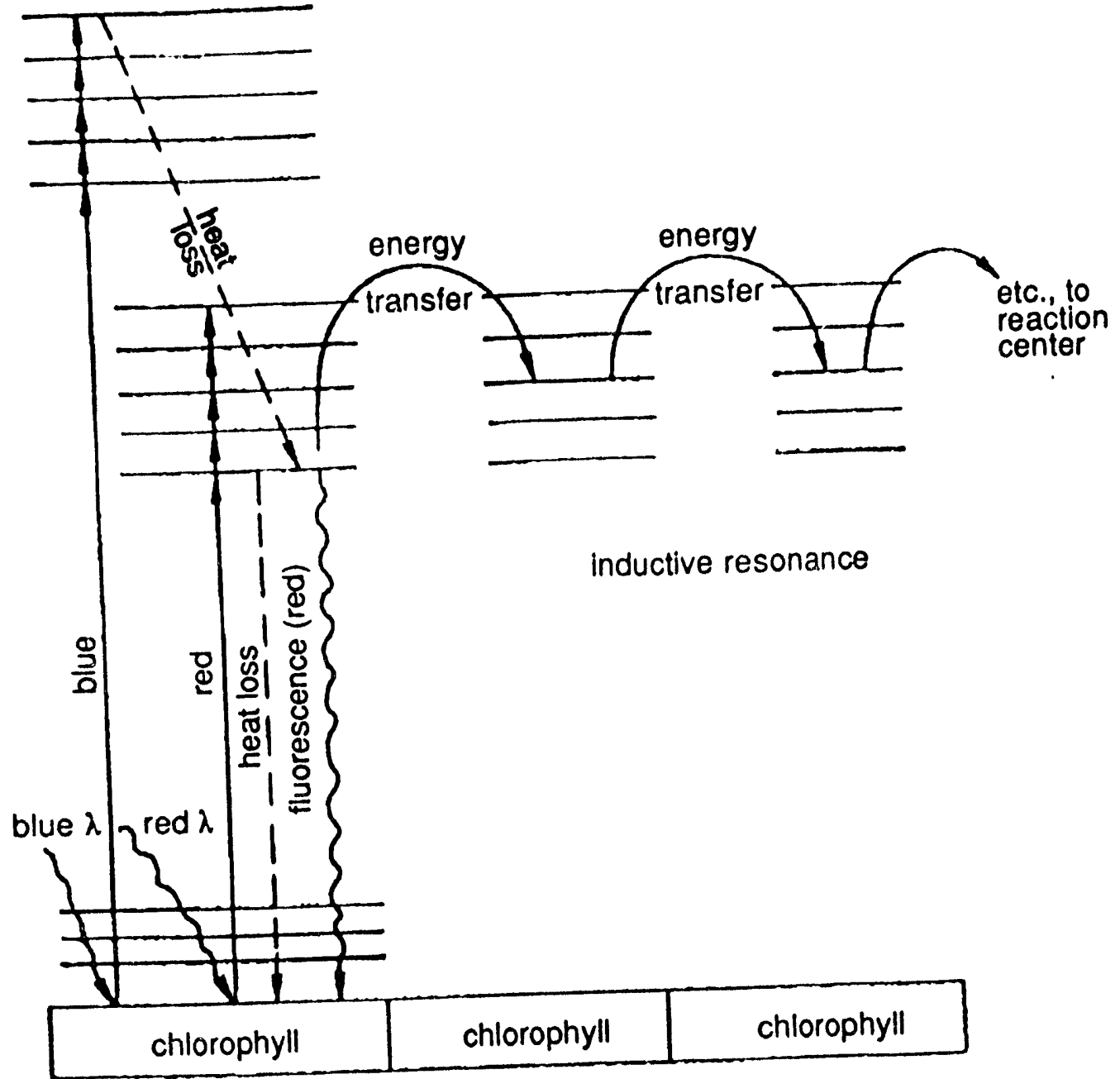

Figure 6.3: Model simplification of how light energy striking a chlorophyll molecule is utilized for photosynthetic reactions (reproduced from Salisbury and Ross, 1979).

as the Calvin-Benson or dark cycle reactions and is shown in Figure 6.5. Starting near the upper left-hand portion of the diagram, carbon dioxide and water are added to ribulose diphosphate to form 3-PGA (3-phosphoglyceric acid). NADPH and ATP are then added and 3-PGA is converted to 3-phosphoglyceraldehyde (3-PGaldehyde), which can be transported outside the chloroplast envelope, for the production of 6 -carbon carbohydrates in the presence of ATP. Alternately, some the 3-PGaldehyde produced remains in the chloroplast and is converted to ribulose-5-phosphate, which is then phosphorylated $\left(\mathrm{PO}_{4}{ }^{3-}\right.$ is added) to create ribulose diphosphate and the reaction can be repeated. 


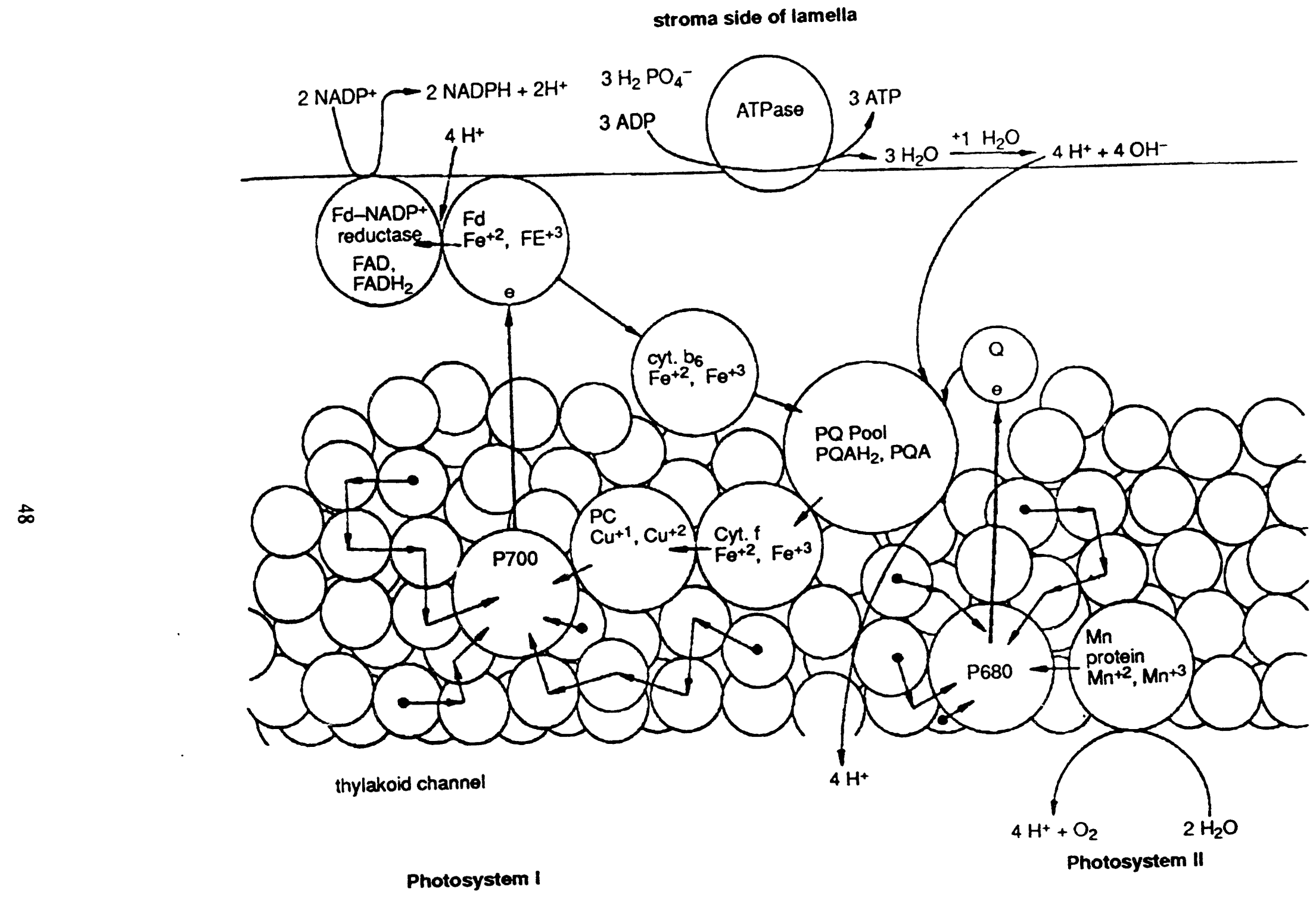
Figure 6.4: Z-scheme representation of electron-transport (light) reactions of photosynthesis. NADPH and ATP are produced
for use in synthesis of six-carbon molecules (Calvin-Benson cycle) (reproduced from Salisbury and Ross, 1979). 


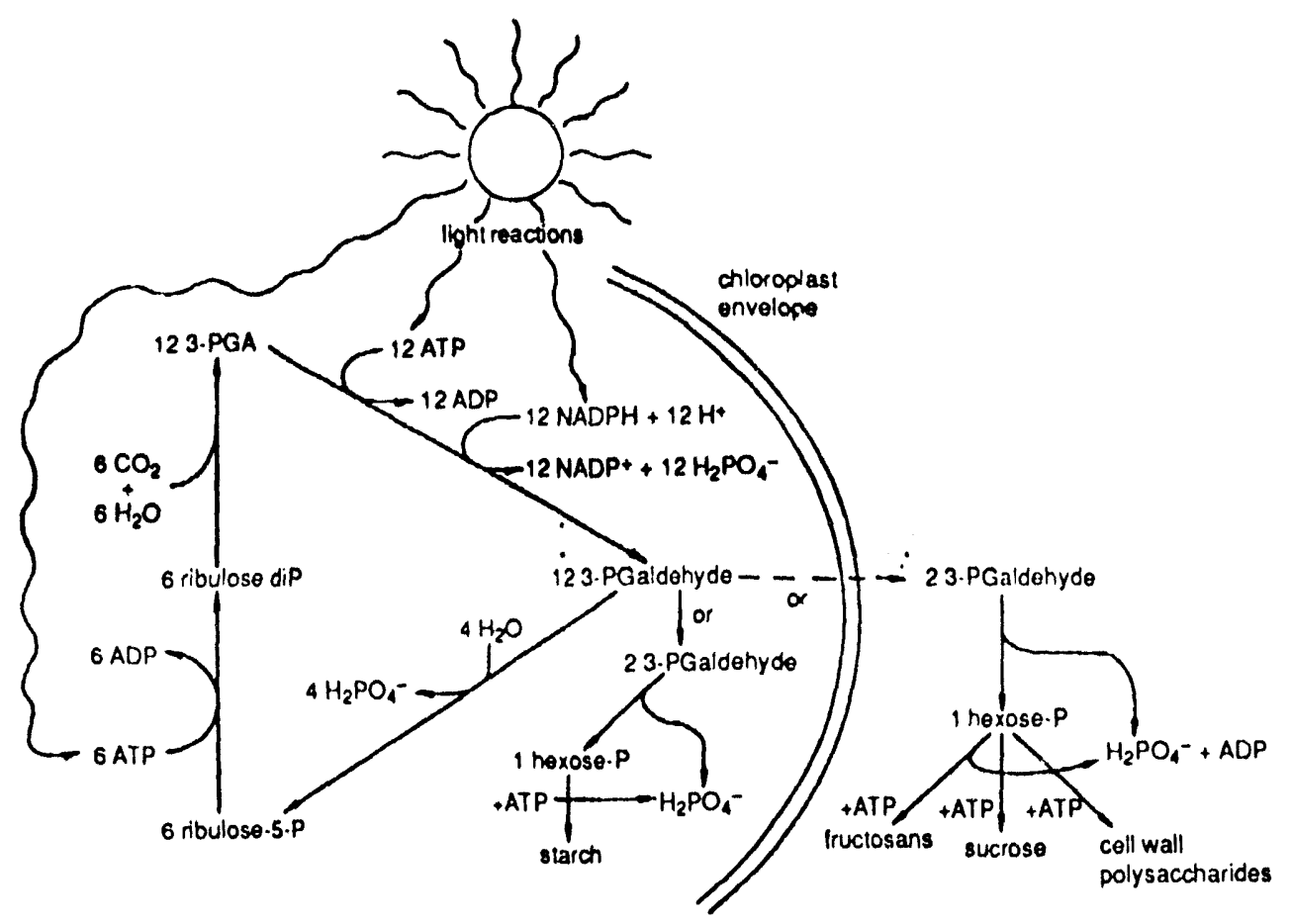

Figure 6.5: Graphic summary of Calvin-Benson (dark) reactions of photosynthesis. The Calvin-Benson reactions use the NADPH and ATP produced in the light reactions to produce 6-carbon "sugars," which are the fuel for respiration (reproduced from Salisbury and Ross, 1979).

\section{Nutrient Uptake}

Water and nutrients are absorbed by plants through root uptake in the soil. Absorption of nutrients is an energy requiring process known as accumulation. In accumulation, nutrients must overcome electrostatic forces that bind nutrients to water and soil particles and a concentration gradient that exists since most nutrients are in greater concentration in plant tissues than in soil. The forces overcome are referred to as the electrochemical potential gradient. The energy required to transport these nutrients, essentially "upstream," is provided by ATP (not respiration); however ATP is produced by respiration, which is the catabolic process by which sugars produced in photosynthesis are translocated to the roots and broken down. Thus, nutrient uptake and photosynthesis work together in a positive feedback loop. Essential nutrients are taken up through the roots and transported to the leaf tissue. These nutrients perform essential functions in photosynthetic reactions that ultimately result in the production of sugar. Sugar is then transported back to the roots and respired to produce ATP, which supplies the energy necessary to take up nutrients against the electrochemical potential gradient. 
Table 6-1 highlights essential functions of nutrientr and their important role in aspects of photosynthesis and chlorophyll development. Nitrogen $(\mathrm{N})$, as one of the two elemental components that comprise the amino group $\left(\mathrm{NH}_{2}\right)$, is found in all proteins as well as all plant lissues. It comprises nearly 50 percent of dry plant matter. Phosphorous (P) is part of ATP, and sulfur (S) is contained in two amino acids (there are 20 in all) that are found in nearly every protein. Iron $(\mathrm{Fe})$, chlorine $(\mathrm{Cl})$, manganese $(\mathrm{Mn})$, and copper $(\mathrm{Cu})$ are all directly involved in the light reactions of photosynthesis, three of which are shown in Figure 6.4. Potassium $\left(\mathrm{K}^{+}\right)$acts as the primary charge-balancing cation during anion transport and controls stomatal opening. Stomates are the "pores" of the leaf, permitting gas exchange and potentially providing arother pathway for contaminant uptake.

One of the ways contaminants can "stress" plants is to replace essential nutrients with part or all of the toxic compound itself. Replacement can occur as a result of the toxin having ar equal or higher electronic affinity than the nutrient just as carbon monoxide $(\mathrm{CO})$ is preferentially absorbed by humans over oxygen when present. Toxins may enter plant tissues below ground at the root zone or aboveground surface through the leaf stomates. Contaminants can also stress plants by binding essential nutrients through chemical reactions, creating a nutrient deficiency in vegetation. While this may be the less common mechanism of stress, it is worth consideration since spectral indications of stress may lack corresponding biogeochemical measurements as the contaminant was not actually incorporated into the plant tissue.

\section{Summary and Conclusions}

Spectral detection of vegetation stress is most typically the result of changes in chlorophyll. The essential plant functions involving chlorophyll (photosynthesis, nutrient uptake, and chlorophyll/chloroplast development) have been reviewed to highlight the numerous avenues that pollutants have to inhibit or interfere with these plant functions. Nearly every nutrient outlined is essential in physiological processes involving chlorophyll. By replacing any one of these nutrients, or causing a nutrient deficiency, pollutants can cause a reduction in chlorophyll concentration through involvement in photosynthetic reactions, nutrient uptake, or chlorophyll development. As discussed in earlier chapters, mild effects on these processes may be detectable through slight shifts in the red edge, while major effects causing foliar damage may be mapped using ratio techniques with existing instrumentation. 
TABLE 6-1: Metabolic roles of essential elements (adapted from Salisbury and Ross, 1979).

Nitrogen: An cssential part of all amino acids, provins (including enzymes), coenzyms. chlorophy 11 molecules, nucleotides and nucle ic acids, and many other plant components.

Phosphorus: Part of ATP and other nucleotides, nucleic acids, certain proteins, several coenzymes, membrane phospholipids, and allached to many different sugars that are important in photosy'nthusis and respiration.

Sulfur: Present in the cssential amino acids cystcine and methionine and thus a part of nearly all proteins; part of a membrane sulfolipid and tho vitamin coensymes thiamine and biotin.

Putassium ( $\left(k^{*}\right)$ : Important in stomatc movements (Ch. 3 ) and activates many enzymes. $K^{*}$ activates protein synthesis in plamts and other organisms. In many cases (e.g., starch and protein synthesis), high concentrations $(0.05 \mathrm{M})$ of $\mathrm{K}^{+}$are required for full enzyme activation. It apparently acts as the primary charge-balancing cation during transport of anions (primarily $\mathrm{NO}_{3}-$, but also $\mathrm{SO}_{4}=$, phosphates, and organic acid anions) from one plant part to another. $\mathrm{K}^{+}$moves readily through xylem phloem, whereas $\mathrm{Ca}^{+2}$ and $\mathrm{Mg}^{+2}$ move readily in xylem, but hardly at all in phlocm. Considerable $\mathrm{K}^{+}$is probably required for this translocation function and for maintaining turgor and activating enzymes; hence, plants require much nolassium (ca. 1 percent of dry H.cight).

Magnesium ( $\left.\mathbf{M g}^{+2}\right)$ : Chelated in and essential to activity of all chlorophyll molecules; also essential for maximum rates of most and perhaps all of hundreds of cnzymatic rcactions involving ATP. Most $\mathrm{Mg}^{+2}$ is apparently bound to ATP, ADP, other nuclcotides, or organic acids. $\mathrm{Mg}^{+2}$ also enhances activity of several other respiratory enzymes and is essential for full activity of the two principal $\mathrm{CO}_{2}$-fixing enzymes, ribulose diphosphate carboxylase and phosphocnolypyruvate carboxylase. $\mathrm{Mg}^{+2}$ is also crucial to protein synthesis (holds two ribosome subunits together and facilitaics peptide bond synthesis).

Calcium $\left(\mathrm{Ca}^{+2}\right)$ : Exists to a great extent in central vacuoles in insoluble crystals of calcium oxalate and $\mathrm{CaCO}_{3}$ (sometimes $\mathrm{CaSO}_{4}$ and $\left.\mathrm{Ca}_{3}\left(\mathrm{PO}_{4}\right)_{2}\right)$, thus kecping possibly toxic oxalates out of the cytoplasm (yct we lack good evidence that failure to do so would harm plants). Some $\mathrm{Ca}^{+2}$ also occurs in the middle lamella between adjacent cell walls, where it is bound to carboxyl groups of pectins; hence, may he important in "cementing" walls together, allhough more evidence is needed.
Iron: Exists in divalent or trivalent froms in c) tochromes and ferredoxin (proleins cssential 10 light-driven reactions of photostulhesis), in cytochromes involved in the milochondrial electron transport system of respiration, in catalase and peroxidase (cnzymes that catalyze the breakdown of toxic $\mathrm{H}_{2} \mathrm{O}_{2}$ into $\mathrm{H}_{2} \mathrm{O}$ and $\mathrm{O}_{2}$ ), and in nitrite reductase and nitrate reduclase (essential to nitrogen inctibolism).

Chlorine(Cl-): Clearly important, but only onc function presently well recognized, the stimulation of photosynthesis by soinchow enhancing electron transfor from $\mathrm{H}_{2} \mathrm{O}$ to chlorophyll in photosystem II. The club shaped root lips of chloride-deficient plants suggest cher undiscovered role(s).

Zinc: Few known important functions in higher plants, one a possible role in synthesis of the amino acid tryptophan and of the hormone auxin. Zinc is also a part of carbonic anhydrase, a chloroplast enzyme that catalyzes the reaction between $\mathrm{CO}_{2}$ and $\mathrm{H}_{2} \mathrm{O}$ to form $\mathrm{H}_{2} \mathrm{CO}_{3}$.

Copper: Essential to photosynthesis, existing in the protein plastocyanin, an electron carricr in the light reactions; essential to respiration (part of cytochrome oxidase.

Molybdenum: Required in the smallest quantitics by plants, its only know'n functions being in nitrate reduction. Plants can be grown in the absence of molybdenum if they are provided with reduced nitrogen $\left(\mathrm{NH}_{4}{ }^{+}\right)$; hence, no other functions may exist.

Manganese: Exists primarily as $\mathbf{M}+2$ in plants but can apparently undergo oxidation (during photosynthesis) to the $\mathrm{Mn}^{+3}$ valence state; like $\mathrm{Cl}^{-}$, enhances electron transfer from $\mathrm{H}_{2} \mathrm{O}$ to chlorophyll; also activates ccrtain enzymes involved in fatty acid synthesis, nuclcotide synthesis (i.e., orotidine-5'-phosphate decarboxylase), respiration, and others. Often activation by $\mathrm{Mn}^{+2}$ is also accomplished by the more abundant $\mathrm{Mg}^{+2} ; \mathrm{Mn}^{+2}$ chelates with phosphate groups in such nuclcotides as ADP and ATP, as does $\mathrm{Mg}^{+2}$.

Boron: Essential for higher plants, which grow slowly and will not complete their life cycles without it; but its biochemical roles are uncertair. Monocots so far investigated gencrally need iess than half as much boron as dicots. Suggested essential roles include: in translocation of sugar (via the phloem), in synthesis of pyrimidine bases (thus, RNA and DNA). 


\subsection{SUMMARY AND CONCLUSIONS}

This document has examined several aspects of remote sensing that may be used to assess contamination on DOE sites in support of Environmental Restoration and Waste Management (ERWM) activities. The remote sensing techniques reviewed have focused on detecting spectral changes in vegetation as a result of anthropogenic and natural environmental conditions. Vegetation was examined for several reasons including its ability to indicate characteristics of both surface and subsurface conditions and its unique spectral signature. If the studies reviewed herein are accepted as evidence of the capability to detect contaminant-induced changes in vegetation using remote sensing, then it seems probable that remote sensing techniques can be more fully developed for successful application with respect to detecting, mapping, and monitoring areas of contamination on DOE sites, and may prove to be a cost-effective method relative to traditional techniques, such as drilling for soil and groundwater analysis. This review reveals a few themes that can either be categorized as fundamental, recurrent, and/or significant and are therefore worthy of recapitulation.

The importance of understanding expected magnitudes of stress has been emphasized at several points throughout this review. The significance of quantifying the magnitude of vegetation stress is illustrated in Figure 7.1. The center (gray-shaded) circle may be considered as ideal conditions, and all points beyond as representing some degree of stress. It may be that the magnitude of stress that typifies geobotanical exploration (the majority of studies discussed in Chapter 2) is so small that it only slightly juxtaposes the population. The forest decline studies in Chapter 4 , on the other hand, would appear to represent the other extreme, where environmental conditions have pushed the vegetation to the outer edges of the gray area in Figure 7.1. While there have been attempts to quantify magnitudes of stress (e.g., Yuan et al., 1989), most have not been conducted in consideration of spectral measurements.

In regards to specific techniques reviewed, it is clear that spectral shifts, either in wavelength positions (horizontal) or percent reflectance (vertical), may be small compared to the signal variation caused by atmospheric and other environmental constraints. Radiometric correction of the "raw" spectral data would appear to be a necessary prerequisite for the detection of vegetation stress when the spectral data are acquired above the canopy. Corrections may range from the relatively simple, such as dark pixel subtraction (e.g., Ahern et al., 1977), to the more sophisticated that account for sun/sensor/target and atmospheric conditions (e.g., Suits, 1972; Lepricur et al., 1988), and beyond. It is highly recommended that some level of correction be applied to raw spectral data collected for purposes of mapping vegetation stress on DOE sites.

Red edge shift detection techniques have received considerable attention in the remote sensing literature in part due to their success in identifying characteristics associated with environmentally stressful conditions that were undetectable by human observation. Another principal advantage of this technique is its apparent insensitivity to mixed pixel problems. Its principal disadvantage is a lack of airborne instrumentation of a resolution necessary to detect the relatively small but consistent findings of red edge shifts towards shorter wavelengths in stressed relative to control samples, especially in laboratory studies. 


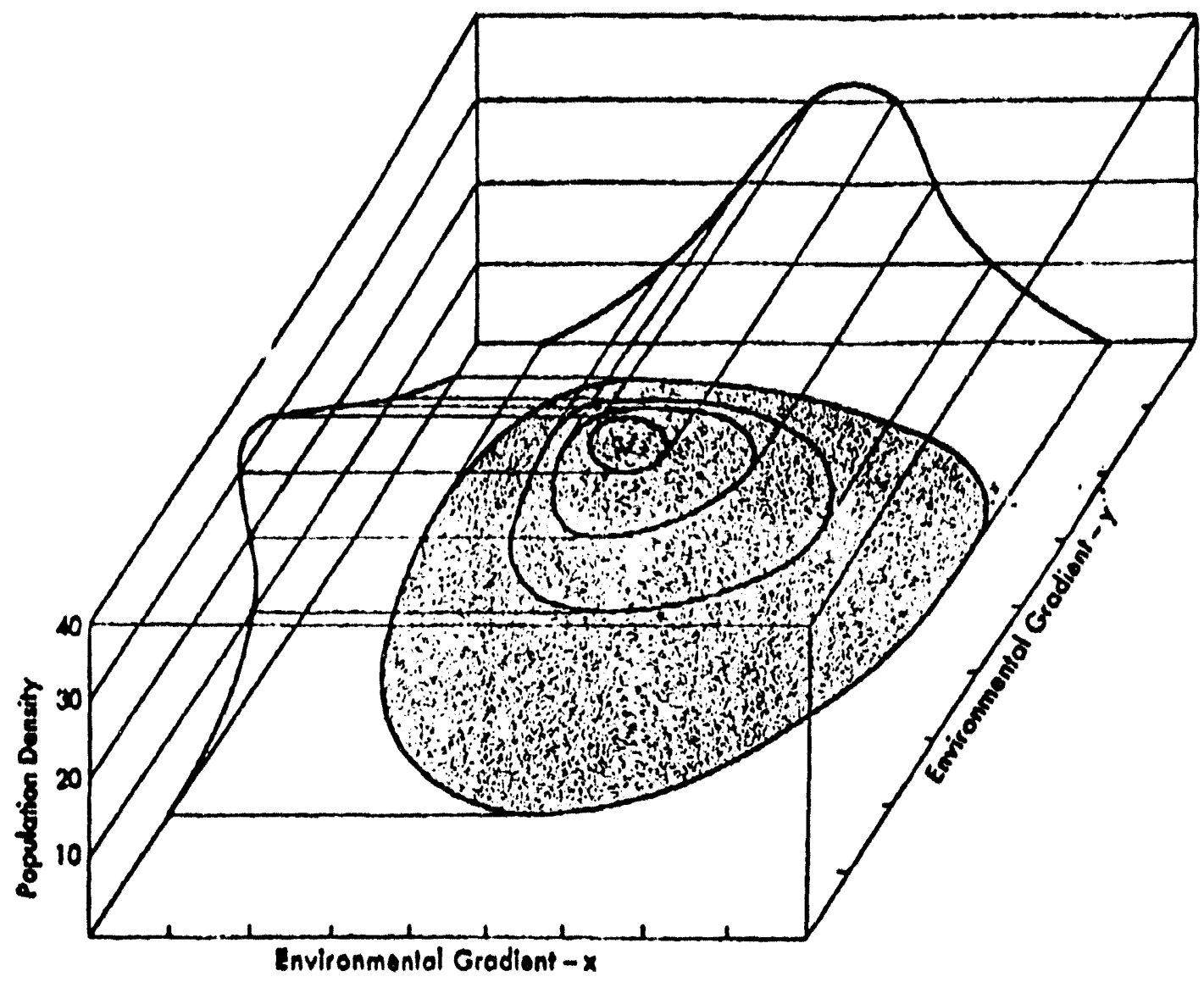

Figure 7.1: Response of population density to changing environmental gradients (reprinted from Whittaker, 1975).

The introduction of wave-form analysis (Collins et al., 1983) and the inverted Gaussian (IG) function (Hare et al., 1984; Miller et al., 1985) represent a fruitful expansion of red edge shift detection techniques, and have stimulated the recognition that the entire spectral profile may be useful for spectral detection of vegetation stress. This has led to the term "full spectral matching," and may become a much more utilized technique as more advanced instrumentation is applied to spectral studies in conjunction with well-characterized spectral curves representing normal and stressed vegetation in relation to specific contaminants. The principal advantage of full spectral matching is that it may allow all of the data collected by a sensor to be used as evidence for determining vegetation stress. A red edge shift may be inconclusive, but several other points along the vegetation spectral profile nay indicate vegetation stress. Full spectral matching allows the interpreter to throw away an inconclusive point without loss of confidence. In addition, the IG function allowed the red edge to be modeled with relatively few data points, permitting application of this technique to both coarse and fine resolution instrumentation.

Comparison of the characteristics of ratio and red edge shift techniques reveals a functional similarity but for different degrees of stress. Greater understanding of spectral responses 
altributable to environmental contamination may allow red edge shift techniques to be operationally applied to mapping and monitoring as opposed to simple detection.

Arid environments may present unique problems regarding mapping and monitoring of vegetation stress. Tueller (1987) has pointed out that ratio techniques, in particular those involving combinations of red and NIR, may be limited in arid environments because of a characteristic lack of greenness. Alternatively, ratio techniques have been successfully used to separate soil from vegetation and technical advances in instrumentation may be necessary for the more subtle distinction between healthy from unhealthy vegetation using these same technicjues.

It is implicitly assumed that contamination of a magnitude to affect vegetation would be of interest to DOE. More than likely, there are areas of contamination, known and unknown, that may not sufficiently affect vegetation to a degree that allows for its detection with current remote sensing technology. Therefore, it is recommended that contamination thresholds for spectral detection be established for contaminants and vegetation species of concern to efficiently apply remote sensing technologies where warranted. In establishing these thresholds, changes in vegetation spectral properties should also be characterized to allow regional remote sensing investigations to search for unique spectral signatures in context of existing site information such as contaminant concentrations established by previous drilling methods. While airborne and satellite collected data offer some excellent characteristics in terms of uniform spatial sampling, the quantity of data can be immense. This emphasizes the necessity of knowing where and what to look for in terms of spectral characteristics for efficient application of this technology.

While many investigators have reported successful regional application of remote sensing techniques for mapping and quantifying vegetation damage as a result of air pollution and pest infestations, these studies have largely examined changes in vegetation of a greater magnitude than expected in many areas of contamination. llowever, their success should not be diminished in that most of these studies succeeded with data of low spectral resolution in a small number of bands. With the recent development of new technology allowing high spectral and spatial resolution from aerial and satellite platforms, there exists the possibility of regionally detecting more subtle changes in vegetation that have generally only been detectable in laboratory and ground-based field studies. In any case, practical application of remote sensing technology should establish baseline conditions over all areas of interest with the best technology available (AVIRIS is suggested). In this manner, temporal effects including changes over time can be more easily detected through subsequent remote sensing investigations. Furthermore, those areas of stressed vegetation identified can be pursued through historically successful ground-based spectral methods as well as more conventional techniques such as drilling.

As many of the techniques reviewed have developed concomitantly with advances in instrumentation that provided data of a quality suitable for their application, it is proposed that acrial surveys with the most advanced sensors available and subsequent distribution of the data will allow many more sensitive techniques to be developed for the detection of contaminantinduced stress in vegetation. It is clear that as instrumentation is developed that can record data of a quality more similar to that of laboratory instruments, successful techniques presently in use in these environments will be applied to remote sensing investigations. 


\subsection{REFERENCES}

Ager, C.M., N.M. Milton, and S.A. Hauck, 1989. Spectral response of vegetation to metallic elements in northea:-n Minnesota using high-resolution airborne scanner dati. Proceedings of the 7th T:eematic Conference on Remote Sensing for Explorition Geolos:?, Calgary, Alberta, Canada. October 2-6. pp. 36-37.

Ahern, F.J., D.G. Goodeno: zh, S.C. Jain, V.R. Rao and G. Rochon, 1977. Use of clear lakes as standard reflectors for atmospheric measurements. Proceedings of 11 ih International Symposium on Remote Sensing of Environment, Ann Arbor, Michigan, pp. 731-755.

Allen, W.A. and A.J. Richardson, 1968. Interaction of light with a plant canopy. Journal of the Optical Society of Ameriea 58:1023-1028.

Ambrosia, V.G., J.S. Myes. T. Bobbe and P. Ishikawa, 1991. Sierra Nevada Forest Stress Determination from A.IRIS Data. Procedings of the 3rd Airborne Visible/ufrated Imaging Spectrometer AVIRIS) Workshop, Pasadena, California, May 20-21, pp. 72--79.

Baret, F., G. Guyot and D.J. Major, 1989. TSAVI: a vegetation index which minimizes soil brightness effects on LAI and APAR estimation. Proceedings of the 12th Canadian Symposium on Remoie Sensing. IGARSS '90. Vancouver, Canada, July 10-14, $3: 1355-1358$.

Banninger, C., 1989. Changes in Canopy Leaf Area Index and Biochemical Constituents of a Spruce Forest as Measured by the AIS-2 Airborne Imaging Spectrometer. Proceedings of IGARSS and the 12th Canadian Symposium on Remote Sensing, Vancouver, Canada, July 10-14, pp. 2085-2089.

Banninger, C., 1991. Thermal Response of a Metal-Stressed Coniferous Forest Measured by the Airborne Thermal Infrared Multispectral Scanner. Proceedings of the 8 th Thematic Conference on Geologic Remote Sensing, Denver, Colorado, April 29-May 2, pp. $1415-1419$.

Bazzaz, F.A., G.L. Rolfe and C.W. Carlson, 1974. Effect of $\mathrm{Cd}$ on Photosynthesis and Transpiration of Excised Leaves of Corn and Sunflower. Physiologia Plantarum 32:373-376.

Beauford, W., J. Barber and A.R. Barringer, 1977. Uptake and Distribution of Mercury Within Higher Plants. Physiology Plants 39:261-265.

Boochs, F., G. Kupfer, K. Dockter and W. Kühbauch, 1990. Shape of the Red Edge as Vitality Indicator for Plants. International Journal of Remore Sensing 11(10):1741-1753.

Boon, D.Y. and P.N. Soltanpour, 1992. Lead, Cadmium, and Zinc Contamination of Aspen Garden Soils and Vegetation. Journal of Environmental Quality 18:82-86.

Boyer, M., J. Miller, M. Belanger, E. Hare and J. Wu, 1988. Senescence and Spectral Reflectance in Leaves of Northern Pin Oak (Quercus palustris Muenchh.). Remote Sensing of Environment 25:71-87. 
Brimns, E., W. Anthony and L. Weatherspoon, 1989. Biological Monitoring of an Agricultural Fond Chain: Soil Cadmium and Lead in Ruminant Tissues. Journal of Environmental Quality 18:317-.323.

Brower, J.E. and J.11. Zar, 1977. Field and Latoratory Methods for General Ecology. Wm. C. Brown Publishers, Dubuque, lowa 194.

Buschmann, C., U. Rinderle and H.K. Lichtenthaler, 1989. Detection of Stress of Coniferous Forest Trees with the VIRAF Spectrometer. Proceedings of IGARSS and the 12 th Canadian Symposium on Remole Sensing, Vancouver, Canada, July 10-14, pp. $2641-2644$.

Bytnerowicz, A., D.M. Olszyk, P.J. Dawson and L. Morrison, 1989. Effects of Air Filtration on Concentration and Deposition of Gaseous and Particulate Air Pollutants in Open ...Top Field Chambers. Journal of Environmental Quality 18:268-273.

Card, D.H., D.L. Peterson, P.A. Matson and J.D. Aber, 1988. Prediction of Leaf Chemistry by the Use of Visible and Near Infrared Reflectance Spectroscopy. Remote Sensing of Environment 26:123-147.

Carlson, R.E., D.N. Yarger and R.H. Shaw, 1971. Factors Affecting the Spectral Properties of leaves with Special Emphasis on Leaf Water Status. Agronomy Journal 63:486-489.

Carlson, R.W., F.A. Bazzaz and G.L. Rolfe, 1975. The Effects of Heavy Metals on Plants. II. Net Photosynthesis and Transpiration of Whole Corn and Sunflower Plants Treated with Pb, Cd, $\mathrm{Ni}$, and T1. Environmental Resource 10:113-120.

Cary, E.E., W.H. Allaway and O.E. Olson, 1977. Control of Chromium Concentrations in Food Plants, Part 2 Chemistry of Chromium in Soils and Its Availability to Plants. Journal of Agricultural and Food Chemistry 25(2):305-309.

Chang, S.H. and W. Collins, 1980. Toxic Effect of Heavy Metals on ''lants. Proceedings of the 6th Annual Pecora Symposium, Sioux Falls, April, pp. 122-124.

Chang, A.C., J.E. Warneke, A.L. Page and L.J. Lund, 1984. Accumulation of Heavy Metals in Scwage Sludge--Treated Soils. Journal of Environmental Quality 13:87-91.

Chang, A.C., A.L. Page, J.E. Warneke, M.R. Resketo and T.E. Jones, 1983. Accumulation of Cadmium and Zinc in Barley Grown on Sludge--Treated Soils: A Long-Term Field Study. Journal of Environmental Quality 12:391-391.

Chappelle, E.W. and D.L. Williams, 1987. Laser Induced Fluorescence (L.IF) from Plant Foliage. IEEE Transactions in Geoscience and Remote Sensing GE-25:726-736.

Chappelle, E.W. J.E. McMurtrey 111 and M.S. Kim, 1991. Identification of the Pigment Responsible for the Blue Fluorescence Band in the Laser Induced Fluorescence (LIF) Spectra of Green Plants, and the Potential Use of this Band in Remotely Estimating Rates of Photosynthesis. Remote Sensing of Environment 36:213-218. 
Chui, H.Y. and W.E. Collins, 1978. A spectroradiometer for airborne remote sensing. Photogrammetric Engineering and Remote Sensing 44:507-517.

Clarkson, D.T. and J. Sanderson, 1969. The Uptake of a Poly Valent Cation and Its Distribution in the Root Apices of Allium-Cepa-M Tracer and Auto Radiographic Studies. Planta Arch Wiss Bot 89(2):136-1.54.

Collins, W., 1978. Remote Sensing of Crop Type and Maturity. Photogrammetric Engineering and Remote Sensing 44(1):43-55.

Collins, W., S.H. Chang, G. Raines, F. Canney and R. Ashley, 1983. Airborne Biophysical Mapping of Hidden Mineral Deposits. Economic Geology 78:737-749.

Conmbes, A.J., N.W. Lepp and D.A. Phipps, 1976. Effect of Copper on IAA-oxidase Activity in Root Tissuc of Barley. Trans. from Z. Pflanzenphysiol. 80:236-242.

Cure, W.W., R.B. Flagler and A.S. Ilagle, 1989. Correlations Between Canopy Reflectance and Leaf Temperalure in Irrigated and Droughted Soybeans. Remote Sensing of Enviromment $29: 273-280$.

Curran, P.J., 1989. Remote Sensing of Foliar Chemistry. Remote Sensing of Environment $30: 271--278$.

Curran, P.J., J.L. Dungan, B.A. Macler and S.E. Plummer, 1991. The Effect of a Red Leaf Pigment on the Relationship Between Red Edge and Chlorophyll Concentration. Remote Sensing of Environment 35:69-76.

Curran, P.J., J.L. Dungan and H.L. Gholz, 1992. Seasonal LAl in Slash Pine Estimated with Landsat TM. Remote Sensing of Environment 39:3-13.

Curtiss, B. and A.G. Maecher, 1991. Changes in Forest Canopy Reflectance Associated With Chronic Exposure to High Concentrations of Soil Trace Metals. Proceedings of the $8 \mathrm{th}$ Thematic Conference on Geologic Remote Sensing, Denver, Colorado, April 29-May 2, pp. 337-347.

Curtiss, B. and S.L. Ustin, 1989. Parameters Affecting Reflectance of Coniferous Forests in the Region of Chlorophyll Pigment Absorption. Proceedings of IGARSS and the 12th Canadian Symposium on Remote Sensing, Vancouver, Canada, July 10-14, pp. 2633-2636.

Danson, F.M., M.D. Steven, T.J. Malthus and J.A. Clark, 1992. High-Spectral Resolution Data for Determining Leaf Water Content. International Journal of Remote Sensing 13(3):461-470.

Das Gupta, B. and S. Mukherji, 1977. Effects of Toxic Concentrations of Copper on Growth and Metabolism of Rice Seedlings. Trans. from Z. Pflanzenphysiol 82:95-106.

Demetriades-Shah, T.H. and M.D. Steven, 1988. High Spectral Resolution Indices for Monitoring Crop Growth and Chlorosis. Proceedings of the 4th International Colloqium on Spectral Signatures of Objects in Remote Sensing. (European Space Agency, Noordwijk, Netherlands, ESA SP-287), pp. 299-302. 
Dowdy, R.H. and W.E. Larson, 1975. The Availability of Sludge-Borne Metals to Various Vegetable Crops. Journal of Environmental Quality 4:278-282.

Ekstrand, S. 1989. The possibilitites of assessing moderate damages on Norway Sprice using Landsat TM data and ancillary stand information in a GIS environment. Proceedings, IGARSS'89 12th Canadian Symposium on Remote Sensing, Vancouver, Canada, July 10-14, 1989, pp. 1553-1557.

Elvidge, C.D., 1988. Thermal Infrared Reflectance of Dry Plant Materials: 2.5-20.0 $\mu \mathrm{m}$. Remote Sensing of Environment 26:265-285.

Gay, D.W. and C.E. Murphy, Jr., 1989. Measurement of the Deposition and Fate of Sulfur-Dioxide-35 in a Pine Plantation. Journal of Environmental Quality 18:337-344.

Gates, D.M., H.J. Keegan, J.C. Schleter and V.R. Weidner, 1965. Spectral properties of plants. Applied Optics 4(1):11-20.

Godbold, D.L. and A. Hüttermann, 1986. The Uptake and Toxicity of Mercury and Lead to Spruce (Picea abies karst) Seedlings. Water, Air, Soil Pollution 31:509-516.

Goward, S.N., C.J. Tucker and D.G. Dye, 1985. North American Vegetation Patterns Observed with the NOAA-7 Advanced Very High Resolution Radiometer. Vegetatio 64:3-14.

Gross, R.E., P. Pugno and W.M. Dugger, 1970. Observations on the Mechanism of Copper Damage in Chlorella. Plant Physiology 46:183-185.

Gulaid, A.A., 1986. Contribution of Remote Sensing to Food Security and Early Warning Systems in Drought Affected Countries in Africa. Proceedings of the 7th International Symposium on Remote Sensing for Resource Development and Environmental Management, ISPRS, A.A. Balkema, Rotterdam, The Netherlands, pp. 457-460.

Hanson, P.J. and S.B. McLaughlin, 1989. Growth, Photosynthesis, and Chlorophyll Concentrations of Red Spruce Seedlings Treated with Mist Containing Hydrogen Peroxide, Journal of Environmental Quality 18:499-503.

Hardisky, M.A., V. Klemas and R.M. Smart. 1983. The influence of soil salinity, growth form, and leaf moisture on spectral radiance of Spartina alterniflora canopies. Photogrammetric Engineering and Remote Sensing 49(1):77-83

Hare, E.W., G.R. Edwards and J.R. Miller, 1984. Geobotanical remote sensing of small localized swamps and bogs in northern Ontario. Proceedings of the International Symposium on Remote Sensing, 3rd Thematic Conference, Remote Sensing for Exploration Geology, Colorado Springs, CO, April 16-19, pp. 671-682.

Herrmann, K., B.N. Rock, U. Ammer and H.N. Paley, 1988. Preliminary Assessment of Airborne Imaging Spectrometer and Airborne Thematic Mapper Data Acquired for Forest Decline Areas in the Federal Republic of Germany. Remote Sensing of Environment $24: 129-149$. 
Holben, B.N., J.B. Schutt and J.E. McMurtrey III, 1983. Leaf Water Stress Detection Utilizing Thematic Mapper Bands 3, 4 and 5 in Soybean Plants. International Journal of Remote Sensing 4:289-297.

Hollinger, A.B., N.T. O'Veill, L.D. Dunlop, M.T. Cooper, H. Edel and J.F.R. Gower, 1985. Water-depth measurement and bottom type analysis using a two-dimensional array imager. Proceedings of the 19 ih International Symposium on Remote Sensing of the Environment, Ann Arbor, Michigan, 21-25 October.

Hoque, E. and P.J.S. Hutzler, 1992. Spectral Blue-Shift of Red Edge Monitors Damage Class of Beech Trees. Remote Sensing of Environment 39:81-84.

Horler, D.N.H., J. Barber and A.R. Barringer, 1980a. Effects of Cadmium and Copper Treatments and Water Stress on the Thermal Emission from Peas (Pisum sativum L.): Controlled Environment Experiments. Remote Sensing of Environment 10:191-199.

Horler, D.N.H., J. Barber and A.R. Barringer, 1980b. Effects of Heavy Metals on the Absorbance and Reflectance Spectra of Plants. International Journal of Remote Sensing, $1(2): 121-136$.

Horler, D.N.H., M. Dockray and J. Barber, 1983. The Red Edge of Plant Leaf Reflectance. International Journal of Remote Sensing 4(2):273-288.

Huete, A.R. 1988. A soil adjusted vegetation index (SAVI). Remote Sensing of Environment 25:295-309.

Huete, A.R., R.D. Jackson and D.F. Post, 1985. Spectral Response of a Plant Canopy with Different Soil Backgrounds. Remote Sensing of Environment 17:37-53.

Hunt, E.R. Jr., B.N. Rock and P.S. Nobel, 1983. Measurement of Leaf Relative Water Content by Infrared Reflectance. Remote Sensing of Environment 22:429-435.

Jackson, R.D., G.A. Jones, G. Uehara and D.T. Santo, 1980. Remote Detection of Nutrient and Water Deficiencies in Sugarcane Under Variable Cloudiness. Remote Sensing of Environment 11:327-331.

Jensen, A., B. Lorenzen, H.S. Østergaard and E.K. Hvelplund, 1990. Radiometric Estimation of Biomass and Nitrogen Content of Barley Grown at Different Nitrogen Levels. International Journal of Remote Sensing 11(10):1809-1820.

Jing, J. and T.J. Logan, 1992. Heavy Metals in the Environment. Journal of Environmental Quality 21:73-81.

Kalisz, P.J., J.W. Stringer, J.A. Volpe and D.T. Clark, 1988. Trees as Monitors of Tritium in Soil Water. Journal of Environmental Quality 17:62-70.

Karr, L. and D.A. Mouat, 1990. A Biogeochemical and Spectral Analysis of Vegetation Affected by External Abiotic Agents: Results of an Investigation from Kitsap County, Washington. NCEL Technical Note, $\mathrm{N}-1822$, sponsored by Naval Facilities Engineering Command, $20 \mathrm{p}$. 
Kauth, R.J. and G.S. Thomas. 1976. The tasseld cap - a graphic description of the spectral-temporal developemnt of agricultural crops as seen by Landsat. Proceedings, Symposium of Machine Processing of Remotely Sensed Data. Purdue University, West Lafayette, IN, pp. 41-51.

Khorram, S., J.A. Brockhaus, R.I. Bruck and M.V. Campbell, 1989. Multitemporal Modeling of Forest Decline from Landsat TM Digital Data. Proceedings of IGARSS and the $12 \mathrm{th}$ Canadian Symposium on Remote Sensing, Vancouver, Canada, July 10-14, pp. 1585-1588.

King, L.D., 1988. Effect of Selected Soil Properties on Cadmium Content of Tobacco. Journal of Environmental Quality 17:251-255.

Kleman, J. and E. Fagerlund, 1987. Influence of Different Nitrogen and Irrigation Treatments on the Spectral Reflectance of Barley. Remote Sensing of Environment 21:1-14.

Knipling, E.B. 1970. Physical and phy'siological basis for the reflectance of visible and near-infrared radiation from vegetation. Remote Sensing of Environment 1:155-159.

Koeppe, D.E., 1991. Lead: Understanding the Minimal Toxicity of Lead in Plants. In: Effect of Heavy Metal Pollution on Plants, N.W. Lepp (ed.), Applied Science Publishers, New Jersey.

Korcak, R.F., 1989. Cadmium Distribution in Field-Grown Fruit Trees. Journal of Environmental Quality 18:519-523.

Labovitz, M.L., E.J. Masuoka, R. Bell, R.F. Nelson, C.A. Larsen, L.K. Hooker and R.W. Troensegaard, 1985. Experimental Evidence for Spring and Autumn Windows for the Detection of Geobotanical Anomalies Through the Remote Sensing of Overlying Vegetation. International Journal of Remote Sensing 6:195-216.

Lamoreaux, R.J. and R.W. Chaney, 1977. Growth and Water Movement in Silver Maple Seedlings Affect by Cadmium. Journal of Environmental Quality 6:201-205.

Leckie, D.G., X. Yuan, D.P. Ostaff, H. Piene and D.A. MacLean, 1992. Analysis of High Resolution Multispectral MEIS Imagery for Spruce Budworm Damage Assessment on a Single Tree Basis. Remote Sensing of Environment 40:125-136.

Lehmann, F., H. RothfuB and R. Richter, 1990. Evaluation of Imaging Spectrometry Data (GER) for the Spectral Analysis of an Old, Vegetation Covered Waste Deposit. Proceedings of the IGARSS Symposium on Remote Sensing, College Park, Maryland, pp. 1613-1616.

Leprieur, C.E., J.M. Durand and J.L. Peyron, 1988. Influence of topography on forest reflectance using Landsat Thematic Mapper and digital terrain data. Photogrammetric Engineering and Remote Sensing 54(4):491-496.

Leprieur, C.E., 1989. Red Edge Measurements and Canopy Structure: A First Look with AVIRIS Data. Proceedings of IGARSS and the 12th Canadian Symposium on Remote Sensing, Vancouver, Canada, July 10-14, pp. 2093-2096. 
Lichtenthaler, H.K., 1989. Possibilities for Remote Sensing of Terrestrial Vegetation by a Combination of Reflectance of Laser-Induced Chlorophyll Fluorescence. Proceedings of IGARSS and the 12th Canadian Symposium on Remote Sensing, Vancouver, Canada, July $10-14$, pp. 1349-1354.

Lichtenthaler, H.K. and C. Buschmann, 1987. Reflectance and Chlorophyll Fluorescence Signatures of Leaves. International Geoscience and Remote Sensing Symposium, Michigan, pp. 1207-1212.

Lichtenthaler, H.K., C. Buschmann, U. Rinderle and G. Schmuck, 1986. Application of Chlorophyll Fluorescence in Ecophysiology. Radiation and Environmental Biophysics 25:297-308.

Lulla, K., R. Howe and P. Mausel, 1982. An Evaluation of Data Enhancement Techniques for a Geobotanical Site: Soldier's Delight, Maryland-Phase 1. Proceedings of the International Symposium on Remote Sensing of Environment, Second Thematic Conference, Remote Sensing for Exploration Geology, Fort Worth, Texas, December 6-10, pp. 97-107.

Lyon, J.G., 1987. Use of Maps, Aerial Photographs, and Other Remote Sensor Data for Practical Evaluations of Hazardous Waste Sites. Photogrammetric Engineering and Remote Sensing 53(5):515-519.

Major, D.J., F. Baret and G. Guyot, 1990. A ratio vegetation index adjusted for soil brightness. Internation Journal of Remote Sensing 11(5):727-740.

Marten, G.C., J.S. Shenk and F.E. Barton (eds.), 1989. Near Infrared Reflectance Spectroscopy (NIRS): Analysis of Forage Quality. USDA/ARS Agriculture Handbook No. 643, 110 p.

McClenahen, J.R., J.P. Vimmerstedt and A.J. Scherzer, 1989. Elemental Concentrations in Tree Rings by Pixe Statistical Variability Mobility and Effects of Altered Soil Chemistry. Canadian Journal of Forest Research 19(7):880-888.

Mikkelsen, R.L., G.H. Haghnia, A.L. Page and F.T. Bingham, 1988. The Influence of Selenium, Salinity, and Boron on Alfalfa Tissue Composition and Yield. Journal of Environmental Quality 17:85-88.

Miller, J.W., E.W. Hare, R.W. Neville, R.P. Gauther, W.D. McColl and S.M. Till, 1985. Correlation of metal concentration with anomalies in narrow band multispectral imagery of the vegetation reflectance red edge. Proceedings of the International Symposium on Remote Sensing, 4th Thematic Conference, Remote Sensing for Exploration Geology, Colorado Springs, CO, April 1-4, Ann Arbor, Michigan, ERIM, pp. 143-153.

Miller, J.R., E.W. Hare and J. Wu, 1990. Quantitative Characterization of the Vegetation Red Edge Reflectance 1. An Inverted-Gaussian Reflectance Model. International Journal of Remote Sensing 11(10):1755-1773. 
Miller, J.R., J. Wu, M.G. Boyer, M. Belanger and E.W. Hare, 1991. Seasonal Patterns in Leaf Reflectance Red-Edge Characteristics. Intemational Journal of Remote Sensing 12(7):1509-1.523.

Milton, E.J. and E.M. Rollin, 1988. A Simplified Reflectance Model for Shrub Canopies. Procecdings of the 4th International Colloquium on Spectral Signatures of Objects in Remote Sensing, Aussois, France, January 18-22.

Milion, N.M., M.S. Power and C.M. Ager, 1988. Spectral Effects of Heavy Metals on Greenhouse-Grown Hosta V'entricosa. U.S. Geological Survey Open-File Report 88-57, 13 p.

Milton, N.M., C.M. Ager, B.A. Eiswerth and M.S. Power, 1989. Arsenic- and Selenium-Induced Changes in Spectral Reflectance and Morphology of Soybean Plants. Remote Sensing of Envirorment 30:263-269.

Milton, N.M., B.A. Eiswerth and C.M. Ager, 1991. Effect of Phosphorus Deficiency on Spectral Reflectance and Morphology of Soybean Plants. Remote Sensing of Environment 36:121-127.

Mislevy, P., W.G. Blue and C.E. Roessler, 1989. Productivity of Clay Tailings from Phosf hate Mining: I. Biomass Crops. Journal of Environmental Quality 18:95-100.

Mouat, D.A., 1982. The Response of Vegetation to Geochemical Conditions. Proceedings of the International Symposium on Remote Sensing of Environment, 2nd Thematic Conference, Remote Sensing for Exploration Geology, Fort Worth, Texas, December 6-10, pp. 75-84.

Norris, K.H., R.F. Barnes, J.E. Moore and J.S. Shenk, 1976. Predicting Forage Quality by Near Infrared Reflectance Spectroscopy. Journal of Animal Science 43:889-897.

O'Connor, G.A., D. Kiehl, G.A. Eiceman and J.A. Ryan, 1990. Plant Uptake of Sludge--Borne PCBs. Journal of Environmental Quality 19:113-118.

Pearson, R.L. and L.D. Miller, 1972. Remote mapping of standing crop biomass for estimation of productivity of the shongrass prairie, Pawnee National Grasslands. Proceedings of the 8 th Internation Symposium on Remote Sensing of Environment, pp. 1357-1379.

Peterson, D.L., M.A. Spanner, S.W. Running and K.B. Teuber, 1987. Relationship of Thematin, Mapper Simulator Data to leaf area index of temperate coniferous forests. Remote Sensing of Environment 22:323-341.

Peterson, D.L., J.D. Aber, P.A. Matson, D.H. Card, N. Swanberg, C. Wessman and M. Spanner, 1988. Remote Sensing of Forest Canopy and Leaf Biochemical Contents. Remote Sensing of Environment 24:85-108.

Pjerce, L.L., S.W. Running and G.A. Riggs, 1990. Remote Detection of Canopy Water Stress in Coniferous Forests Using the NSO01 Thematic Mapper Simulator and the Thermal Infrared Multispectral Scanner. Photogrammetric Engineering and Remote Sensing 56(5):579-586. 
Pinder, J.E., III and K.W. McLeod, 1988. Contaminant Transport in Agroecosystems Through Retention of Soil Particles on Plant Surfaces. Journal Environmental Quality 17:602-607.

Prasad, D.D.K. and A.R.K. Prisad, 1987. Effect of Lead and Mercury on Chlorophyll Synthesis in Mung Bean Seedlings. Phytochemistry 26(4):881-884.

Quarmby, N.A., J.R.G. Townshend, J.J. Settle, K.H. White, M. Milnes, T.L. Hindle and N. Silleos, 1992. Linear Mixture Modelling Applied to AVHRR Data for Crop Area Estimation. International Journal of Remote Sensing 13(3):415-425.

Rhoads, F.M., S.M. Olson and A. Manning, 1989. Copper Toxicity in Tomato Plants. Journal of Environmental Quality 18:195-197.

Richardson, A.J. and C.I. Wiegand, 1977. Distinguishing vegetation from soil-background information. Photogrammetric Engineering and Remote Sensing 43:1541-1552.

Richardson, A.J. and J.H. Everitt, 1992. Using spectral vegetation indices to estimate rangeland productivity. Geocarto International 1:63-69.

Riggs, G.A. and S.W. Running, 1991. Detection of Canopy Water Stress in Conifers Using the Airborne Imaging Spectrometer. Remote Sensing of Environment 35:51-68.

Riley, R.G. and J.M. Zachara, 1991. (DRAFT) Nature of Chemical Contaminants on DOE Lands and Identification of Representative Contaminant Mixtures for Basic Subsurface Science Research. Prepared for the U.S. Department of Energy under Contract DE-AC06-76RLO 1830, 66 p.

Robb, J., L. Busch and W.E. Rauser, 1980. Zinc Toxicity and Xylem Vessel Alterations in White Beans. Annual Botany 46:43-50.

Roberts, D.A. and R.O. Green, 1985. Detection of Hydrocarbon Microseeps and Related Geobotanical Anomalies Using Multi-Date Image Subtraction, Railroad Valley, Nevada. Proceedings of the 19th International Symposium on Remote Sensing of Environment, Ann Arbor, Michigan, October 21-25, pp. 323-332.

Rock, B.N., J.E. Vogelmann, D.L. Williams, A.F. Vogelmann and T. Hoshizaki, 1986. Remote Detection of Forest Damage. Bioscience 36:439-445.

Rock, B.N., T. Hoshizaki and J.R. Miller, 1988. Comparison of In Situ and Airborne Spectral Measurements of the Blue Shift Associated with Forest Decline. Remote Sensing of Environment 24:109-127.

Rosema, A., G. Cecchi, L. Pantani, B. Radicatti, M. Romuli, P. Mazzinghi, O. Van Kooten and C. Kliffen, 1992. Monitoring Photosynthetic Activity and Ozone Stress by Laser Induced Fluorescence in Trees. International Journal of Remote Sensing 13(4):737-751.

Rost, T.L., M.G. Barbour, R.M. Thornton, T.W. Weier and C.R. Stocking. 1979. Botany: A Brief Introduction to Plant Biology. 5th Ed. John Wiley \& Sons, New York, USA, 118 p. 
Rouse, J.W., R.H. Hass, J.A. Schell, D.W. Deering and J.C. Harlan, 1974. Monitoring the vernal advancement of retrogradation (greenwave effect) of natural vegetation. NASA/GSFC Type III Final Report. Greenbelt, MD, 371 p.

Running, S.W. and R.R. Nemani, 1988. Relating Seasonal Patterns of AVHRR Vegetation Index to Simulated Photosynthesis and Transpiration of Forests in Different Climates. Remote Sensing of Environment 24:347-368.

Running, S.W., D.L. Peterson, M.A. Spanner and K.B. Teuber, 1986. Remote Sensing of coniferous forest leaf area. Ecology 67(1):273-276.

Sabins, F.F. 1987. Remote Sensing: Principles and Interpretation. 2nd Ed. W.H. Freeman and Company, San Francisco, USA, 719 p.

Salisbury, F.B. and C.W. Ross, 1979. Plant Physiology. 2nd Ed. Wadsworth Publishing Co., Belmont, California, $540 \mathrm{p}$.

Sampson, M., D.T. Clarkson and D.D. Davies, 1965. DNA Synthesis in Aluminum Treated Roots of Barley. Science 148:1476-1477.

Schenk, J.S., M.O. Westerhaus and M.R. Hoover, 1979. Analysis of Forages by Near Infrared Reflectance Spectroscopy. Yournal of Dairy Science 62:807-812.

Scherzer, A.J. and J.R. McClenahen, 1989. Effects of Ozone or Sulfur Dioxide on Pitch Pine Seedlings. Journal of Environmental Quality 18:57-61.

Schier, G.A., C.J. McQuattie and K.F. Jensen, 1990. Effect of Ozone and Aluminum on Pitch Pine Pinus-Rigida Seedlings Growth and Nutrient Relations. Canadian Journal of Forest Research 20(11):1714-1719.

Schwaller, M.R., 1982. Discrimination of Metal Stressed and Non-Stressed Vegetation in Simulated Soil-Vegetation Ensembles. Proceedings of the International Symposium on Remote Sensing of Environment, Second Thematic Conference, Remote Sensing for Exploration Geology, Fort Worth, Texas, December 6-10, pp. 679-692.

Schwaller, M.R. and S.J. Tkach, 1980. Premature Leaf Senescence as an Indicator in Geobotanical Prospecting with Remote Sensing Techniquies. Proceedings of the 14th International Symposium on Remote Sensing of the Environments, San Jose, Costa Rico, pp. 347-358.

Schwaller, M.R., C.C. Schnetzler and P.E. Marshall, 1981. The Changes in Leaf Reflectance of Sugar Maple Seedlings (Acer saccharum Marsh) in Response to Heavy Metal Stress. NASA Technical Memorandum 82150, 13 p.

Shutt, J.B., R.R. Rowland and W.H. Heartly, 1984. A laboratory investigation of a physical mechanism for the extended infrared absorption ('red shift') in wheat. Internation Journal of Remote Sensing 5:92-102. 
Siegal, B.D. and A.R. Gillespie, 1980. Remote Sensing in Geology. John Wiley \& Sons, New York, USA, 702 p.

Singhroy, V.H. and F.A. Kruse, 1991. Detection of Metal Stress in Boreal Forest Species Using the $0.67 \mu \mathrm{m}$ Chlorophyll Absorption Band. Proceedings of the 8ih Thematic Conference on Geologic Remote Sensing, Denver, Colorado, April 29-May 2, pp. 361-372.

Singhroy, V.H., F. Kenny and J. Springer, 1989. Reflectance Spectra of Vegetation Growing on Mine Sites in the Canadian Shield. Proceedings of IGARSS and the 12th Canadian Symposium on Remote Sensing, Vancouver, Canada, July 10-14, pp. 665-669.

Steinmetz, S., M. Guerif, R. Delecolle and F. Baret, 1990. Spectral Estimates of the Absorbed Photosynthetically Active Radiation and Light-Use Efficiency of a Winter Wheat Crop Subjected to Nitrogen and Water Deficiences. International Journal of Remote Sensing 11(10):1797-1808.

Stobard, A.K., W.T. Griffiths, Ameen Bukhari and R.P. Sherwood, 1985. The Effect of Cd on the Biosynthesis of Chlorophyll in leaves of Barley. Physiology of Plant 63:293-298.

Suits, G.H., 1972. The Calculation of the Directional Reflectance of a Vegetative Canopy. Remote Sensing of Environment 2:117-125.

Suresh, R., C.D. Foy, J.R. Weidner, C.S. Schnetzler and M.R. Schwaller, 1989. Effect of Metal Stress on the Thermal Infrared Emission of Soybeans: A Greenhouse Experiment - Possible Utility in Remote Sensing. International Journal of Remote Sensing 10(3):557-563.

Takkar, P.N. and T. Mann, 1978. Toxic Levels of Soil and Plant $Z_{n}$ for Maize and Wheat. Plant Soil 49:667-669.

Tanre, D. P. Dahaut, M. Herman, J.J. Morcrette, J. Perbos and P.Y. Deschamps, 1986. Effets atmosperiques en te' le de tecion. Logiciel de simulation du signal satelliteaire dans le spectre solaire. Proceedings of the 3rd International Colloquium on Spectral Signatures of Objects in Remote Sensing, Les Arcs (France). ESA SP-247:315-319.

Tennakoon, S.B., V.V.N. Muny and A. Eiumnoh, 1992. Estimation of Cropped Area and Grain Yield of Rice Using Remote Sensing Data. International Journal of Remote Sensing 13(3):427-439.

Thompson, D.R. and O.A. Wehmanen, 1979. Using Landsat digital data to detect moisture stress. Photogrammetric Engineering and Remote Sensing 45(2):210-207.

Townshend, J.R.G. and C.O. Justice, 1986. Analysis of the Dynamics of African Vegetation Using the Normalized Difference Vegetation Index. International Journal of Remote Sensing 7:1435 1446.

Tucker, C.J. 19.80. Remote sensing of leaf water content in the near infrared. Remote Sensing of Environment 10:23-32. 
Tucker, C.J. and J.O. Justice, 1986. Satellite remote sensing of desert spatial extent. Desertification Control Bulletin 13:2-5.

Tucker, C.J., I.Y. Fung, C.D. Keeling and R.H. Gammon, 1986. Relationship Between Atmospheric $\mathrm{CO}_{2}$ Variations and a Satellite-Derived Vegetation Index. Nature 319:195-199.

Tueller, P.T., 1987. Remote Sensing Science applications in arid environments. Remote Sensing of Environment 23:143-154

Vanderbilt, V.C., L. Grant, I.L, Biehl and B.F. Robinson. 1985. Specular, diffuse, and polarized light scattered by two wheat canopies. Applied Optics 24:2408-2418.

Vanderbilt, V.C., S.L. Ustin and J. Clark, 1988. Canopy Geometry Changes Duc to Wind Cause Red Edge Spectral Shift. Proceedings of the IGARSS 1988 Symposium, Edinburgh, Scotland, Seprember 13-16, pp. 835.

Verhoef, W. 1984. Light scaltering by leaf layers iwth applications to canopy reflectance modeling: the SAIL model. Remote Sensing of Environment 16:125-141.

Vogelmann, J.E., 1990. Comparison Between Two Vegetation Indices for Measuring Different Types of Forest Damage in the North-Eastern United States. International Journal of Remote Sensing 11(12):2281-2297.

Vogelmann, J.E. and B.N. Rock, 1986. Assessing Forest Decline in Coniferous Forests of Vermont Using NSO01 Thematic Mapper Simulator Data. International Journal of Remote Sensing 7(10):1303-1321.

Vogelmann, J.E. and B.N. Rock, 1988. Assessing Forest Damage in High-Elevation Coniferous Forests of Vermont and New Hampshire using Landsat Thematic Mapper Data. Remote Sensing of Environment 24:227-246.

Weigel, H.J., 1985. The Effect of $\mathrm{Cd}^{+2}$ on Photosynthetic Reactions of Mesophyll Protoplasts. Physiology of Plant 63:192-200.

Wessman, C.A., J.D. Aber, D.L. Peterson and J.M. Melillo, 1987. Foliar Analysis Using Near Infrared Reflectance Spectroscopy. Canadian Journal of Forest Research 18:6-11.

Westman, W.E. and C.V. Price, 1987. Remote Detection of Air Pollution Stress to Vegetation: Laboratory-level Studies. Proceedings of the IGARSS 1987 Symposium, Ann Arbor, Michigan, May 18-21, pp. 451-456.

Whittaker, R.H. 1975. Communities and Ecosystems. 2nd Ed. MacMillan Publishing Company, New York, USA, 385 p.

Williams, D.L., 1991. A Comparison of Spectral Reflectance Properties at the Needle, Branch, and Canopy Level for Selected Conifer Species. Remote Sensing of Environment 35:79-93. 
Williams, D.L. and R.F. Nelson, 1984. The Effect of Spatial, Spectral and Radiometric Factors on Classification Accuracy Using Thematic Mapper Data. Proceedings of the IGARSS Symposium, Strassbourg. August 27-30, pp. 93-100.

Williams, P.C., K.H. Norris, C.W. Gehrke and K. Bernstein, 1983. Comparison of Near-Infrared Methods for Mcasuring Protein and Moisture in Wheat. Cereals Food World 28:149-152.

Wu, L., A.D. Bradshaw and D.A. Thurman, 1975. The Potential for Evolution of Heavy Metal Tolerance in Plants: III. The Rapid Evolution of Copper Tolerance in Agrostis stolonifera. Heredity $34: 165$

Yuan, X., J. Vlcek, D. King and D. McLaughlin, 1989. Application of Aerial Multispectral Videography and Colour/Colour IR Photography' in Sugar Maple Decline Assessment. Procedings of IGARSS and the 12th Canadian Symposium on Remote Sensing, Vancouver, Camada, July 10-14, pp. 2385-2389.

Zilioli, E., M.A. Gomarasca and R. Tomasoni, 1992. Application of Terrestrial Thermography to the Detection of Waste-Disposal Sites. Remote Sensing of Environment 40:153-160. 


\section{APPENDIX 1}

Summary of Studies Examining Plant Responses to Certain Chemical Compounds 
SUMMARY OF STUDIES EXAMINING PLANT RESPONSES TO CERTAIN CHEMICAL COMPOUNDS.

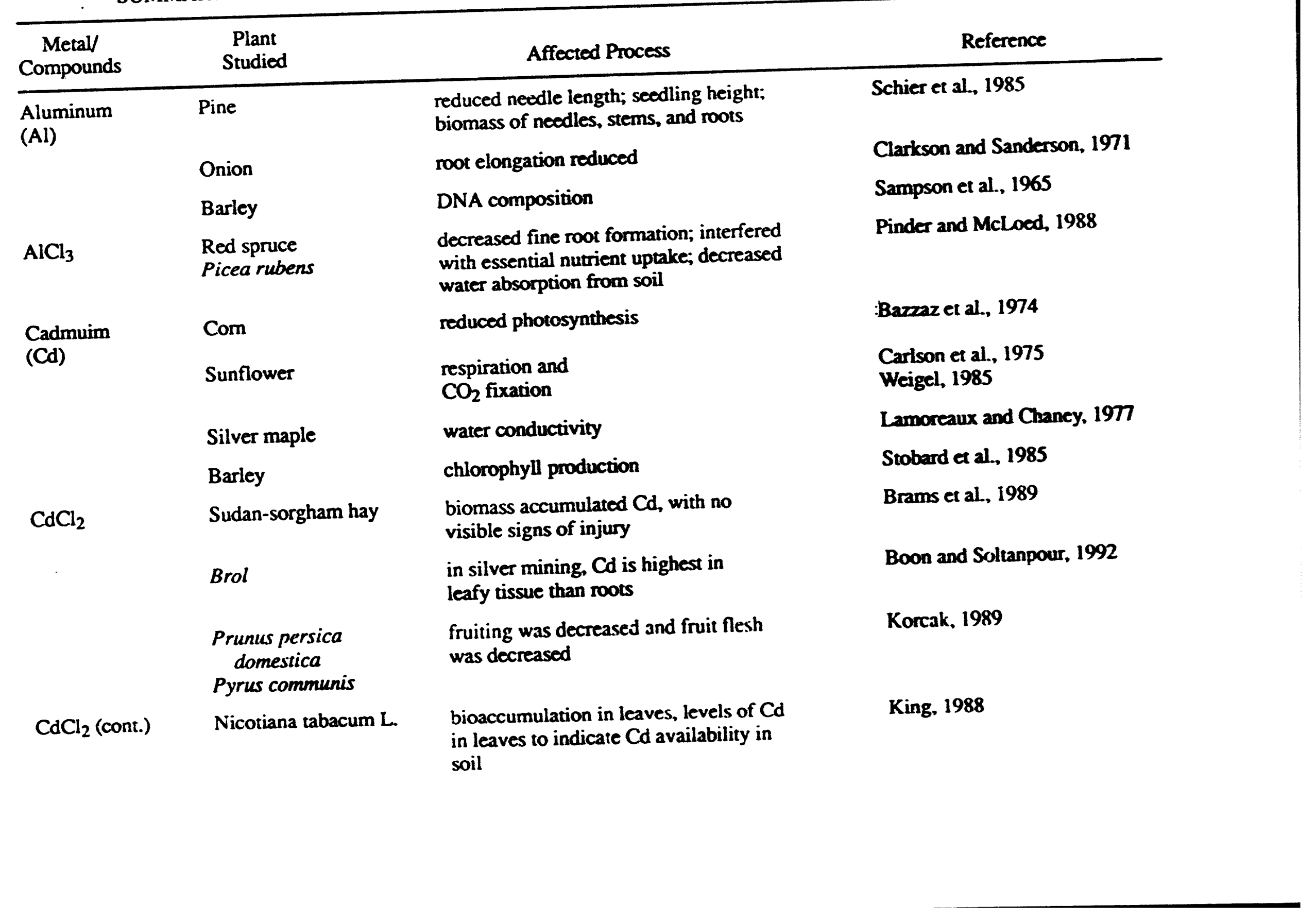


SUMMARY OF STUDIES EXAMINING PLANT RESPONSES TO CERTAIN CHEMICAL COMPOUNDS (continued).

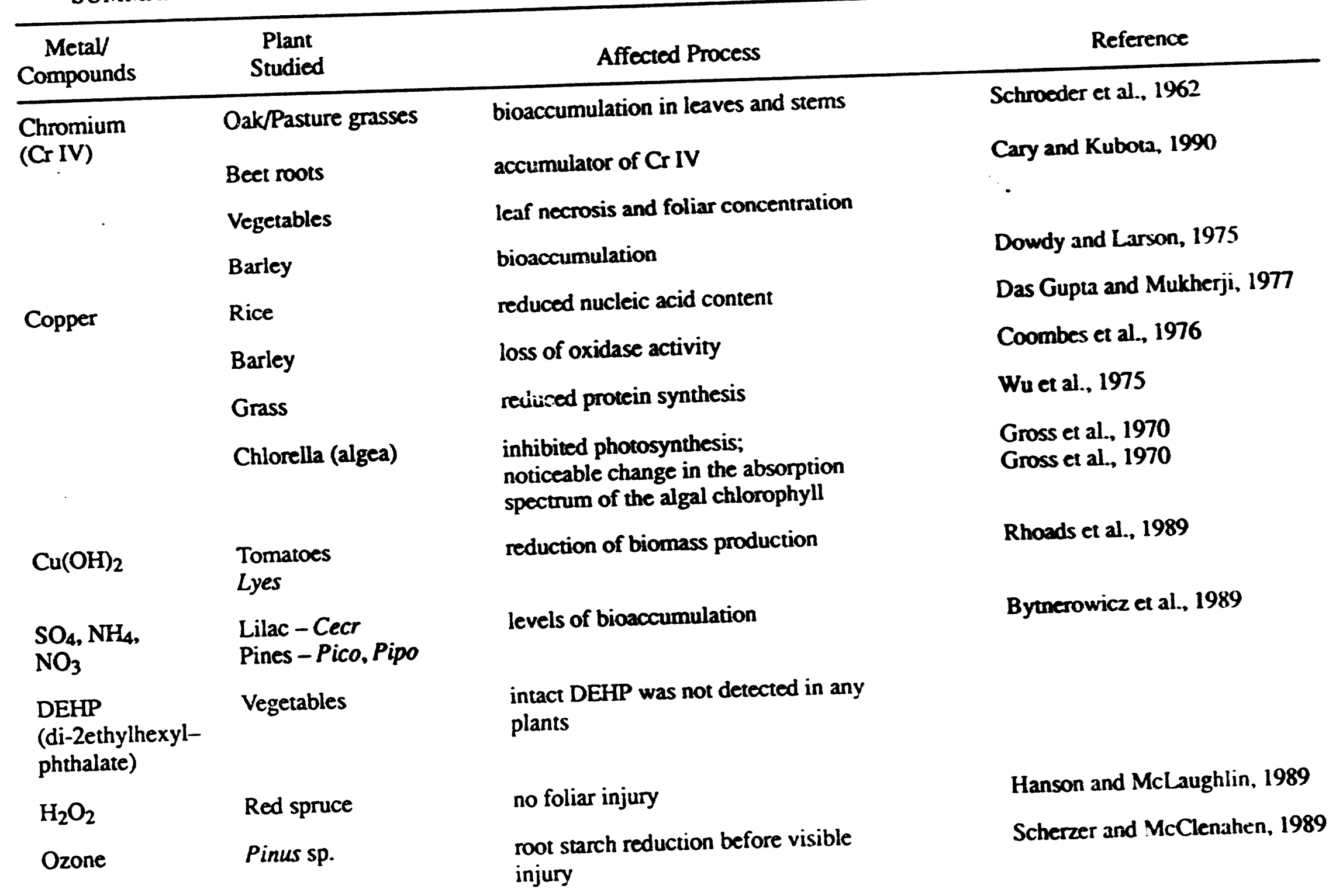


SUMMARY OF STUDIES EXAMINING PLANT RESPONSES TO CERTAIN CHEMICAL COMPOUNDS (continued).

\begin{tabular}{|c|c|c|c|}
\hline $\begin{array}{l}\text { Metal } \\
\text { Compounds }\end{array}$ & $\begin{array}{l}\text { Plant } \\
\text { Studied }\end{array}$ & Affected Process & Reference \\
\hline \multirow[t]{4}{*}{ Zinc } & WheatMaize & leaf turns blue-green at tips and dries out & Takkar and Mann, 1978 \\
\hline & Barley & bioaccumulation in all plant parts & Chang et al., $1983 \& 1984$ \\
\hline & Beans & xylem vessel alterations & Robb et al., 1980 \\
\hline & Brol & $\begin{array}{l}\text { in silver mining, leafy tissue } \\
\text { concentrations were highest }\end{array}$ & Boon and Soltanpour, 1992 \\
\hline \multirow[t]{2}{*}{$\begin{array}{l}\text { Mercury } \\
(\mathrm{Hg})\end{array}$} & Rice & root growth, germination & $\begin{array}{l}\text { Beauford et al., } 1977 \\
\text { Prasad and Prasad, } 1987\end{array}$ \\
\hline & Most plants & $\begin{array}{l}\text { inhibits water uptake synthesis of } \\
\text { protein chlorophyll production }\end{array}$ & \\
\hline $\mathrm{CH}_{3} \mathrm{HgCl}$ & Spruce & $\begin{array}{l}\text { seeding root elongation reduction } \\
\text { within one day }\end{array}$ & Godgold and Hutterman, 1986 \\
\hline \multirow[t]{2}{*}{$\begin{array}{l}\text { Lead } \\
(\mathrm{Pb}) \\
\text { aerosol }\end{array}$} & $\begin{array}{l}\text { Microflora on leaf } \\
\text { surface }\end{array}$ & $\begin{array}{l}\text { potential toxin in the food chain when } \\
\text { ingested when on plant surfaces, but } \\
\text { not toxic to plants }\end{array}$ & Koeppe, 1991 \\
\hline & Brassica oleracea & $\mathrm{Pb}$ not accumulated in leaves & Boon and Soltanpour, 1992 \\
\hline $\mathrm{Pb}\left(\mathrm{NO}_{3}\right)_{2}$ & Sudan-sorgham hay & $\begin{array}{l}\text { biomass did not accumulate } \mathrm{Pb} \text {, no } \\
\text { visible signs of effected tissue }\end{array}$ & Brams et al., 1989 \\
\hline PCBs & Fescue & no detectable levels $>20 \mathrm{ug} / \mathrm{Kg}$ & O'Connor et al., 1990 \\
\hline \multirow[t]{2}{*}{ PCBs (cont.) } & Carrot & $\begin{array}{l}\text { detectable in peels; peels are rich in } \\
\text { lipid rich epidermal layer }\end{array}$ & \\
\hline & Lettuce & not detectable & \\
\hline
\end{tabular}


SUMMARY OF STUDIES EXAMINING PLANT RESPONSES TO CERTAIN CHEMICAL COMPOUNDS (continued).

\begin{tabular}{|c|c|c|c|}
\hline $\begin{array}{c}\text { Metal/ } \\
\text { Compounds }\end{array}$ & $\begin{array}{l}\text { Plant } \\
\text { Studied }\end{array}$ & Affected Process & Reference \\
\hline Radium-226 & $\begin{array}{l}\text { Grasses - Pepu, } \\
\text { Lele Lam., Ecpo, } \\
\text { Erar, Deci, Sobi }\end{array}$ & $\begin{array}{l}\text { bioaccumulation }-226 \mathrm{Ra} \text { concentration } \\
\text { is } 6 \text { times higher in plant tissue when } \\
\text { grown on tailings from phosphate mines }\end{array}$ & Mislevy et al., 1989 \\
\hline $\mathrm{Se}$ (IV) & Alfalfa & $\begin{array}{l}\text { plant dry weights decreased from } 37 \rightarrow \\
29.6 \mathrm{~g} \text {; Se accumulated in plant proportional } \\
\text { to solution Se (VI) concentration }\end{array}$ & Mikkelsen et al., 1988 \\
\hline $\mathrm{SO}_{2}$ & Loblolly pine & $\begin{array}{l}\text { distributed in the chloroplast; chlorphyll } \\
\text { material }\end{array}$ & Gay and Murphy, 1989 \\
\hline $\begin{array}{l}\text { Tritium } \\
\& \text { other water } \\
\text { radionuclides } \\
{ }^{60} \mathrm{Co} \\
{ }^{238} \mathrm{Pu}\end{array}$ & Quercus alba & $\begin{array}{l}\text { monitors } 3 \mathrm{H} \text { in soil because of deep } \\
\text { roots; } 3 \mathrm{H} \text { activities in foliage reflect } \\
3 \mathrm{H} \text { activities in the soil water }\end{array}$ & Kalisz et al., 1988 \\
\hline
\end{tabular}




\section{APPENDIX 2}

Contaminants of Interest to

DOE and Other Agencies 


\section{Contaminants of Interest to DOE and Other Agencies}

The following individual contaminants and mixtures were identified in the ground at 91 waste sites at 18 DOE facilities within the weapons complex. These data come from the repont by R. G. Riley and J. M. Zachara (1992) entitled "Nature of Chemical Contaminants on DOE Lands and Identification of Representative Contaminant Mixtures For Basic Subsurface Science Research."

Fuel hydrocarbons, chlorinated hydrocarbons, radionuclides, metals, inorganic anions, and ketones were the contaminant classes most frequently measured in the ground at DOE facilities.

The chlorinated hydrocarbon, fuel hydrocarbon, radionuclide(s), metal(s), and ketone reported in groundwater most frequently were trichloroethylene, toluene, tritium/uranium, lead/chromium, and acetone, respectively.

Binary contaminant mixtures were reported at 64 percent of the waste sites and ternary mixtures were observed at 49 percent of the sites. Information on the contaminants and their in-ground combinations was used to generate generic mixtures for future research. These mixtures include:

- Chlorinated hydrocarbons and fuel hydrocarbons.

- Metals/anions and radionuclides.

- Organic solvents and PCBs.

- Metals/radionuclides and organic acids.

- Metals/radionuclides and complexing agents.

- Metals/radionuclides and ketones.

- Metals/radionuclides, organic acids/complexing agents, and organic solvents.

- Metals/radionuclides and natural organic substances.

The above mixtures all have equal priority for research, based on the frequency of their occurrence, their likelihood to influence contaminant dynamics, and the extent of research knowledge.

The following are the 25 most frequently identified substances at 546 Superfund sites (adapted from McCoy \& Assoc. "Haz. Waste. Consult." 3:2(1985):

\section{Substance Percent of Sites}

Trichloroethylene ................. 33

Lead and compounds .............. 30

Toluene ........................ 28

Benzene .................... 26

Polychlorinated biphenyls ........... 22

Chloroform ................... 20 
Tetrachloroethylene $\ldots \ldots \ldots \ldots \ldots \ldots \ldots \ldots 16$

Phenol ........................ 15

Arsenic and compounds ............. 15

Cadmium and compounds . . . . . . . . . 15

Chromium and compounds ........... 15

$1,1,1$-Trichloroethane .............. 14

Zinc and compounds ............. 14

Ethylbenzene ................... 13

Xylene ..................... 13

Methylene chloride $\ldots \ldots \ldots \ldots \ldots \ldots \ldots \ldots 12$

trans-1,2-Dichloroethylene ............11

Mercury ...................... 10

Copper and compounds . . . . . . . . . 9

Cyanides (soluble salts) $\ldots \ldots \ldots \ldots \ldots \ldots \ldots 8$

Vinyl chloride ................. 8

1,2-Dichloroethane ............. 8

Chlorobenzene ................ 8

1,1-Dichloroethane .............. 8

Carbon tetrachloride ................ 8

The following are the frequency of substances reported at final National Priorities List Sites as of March 14, 1991:

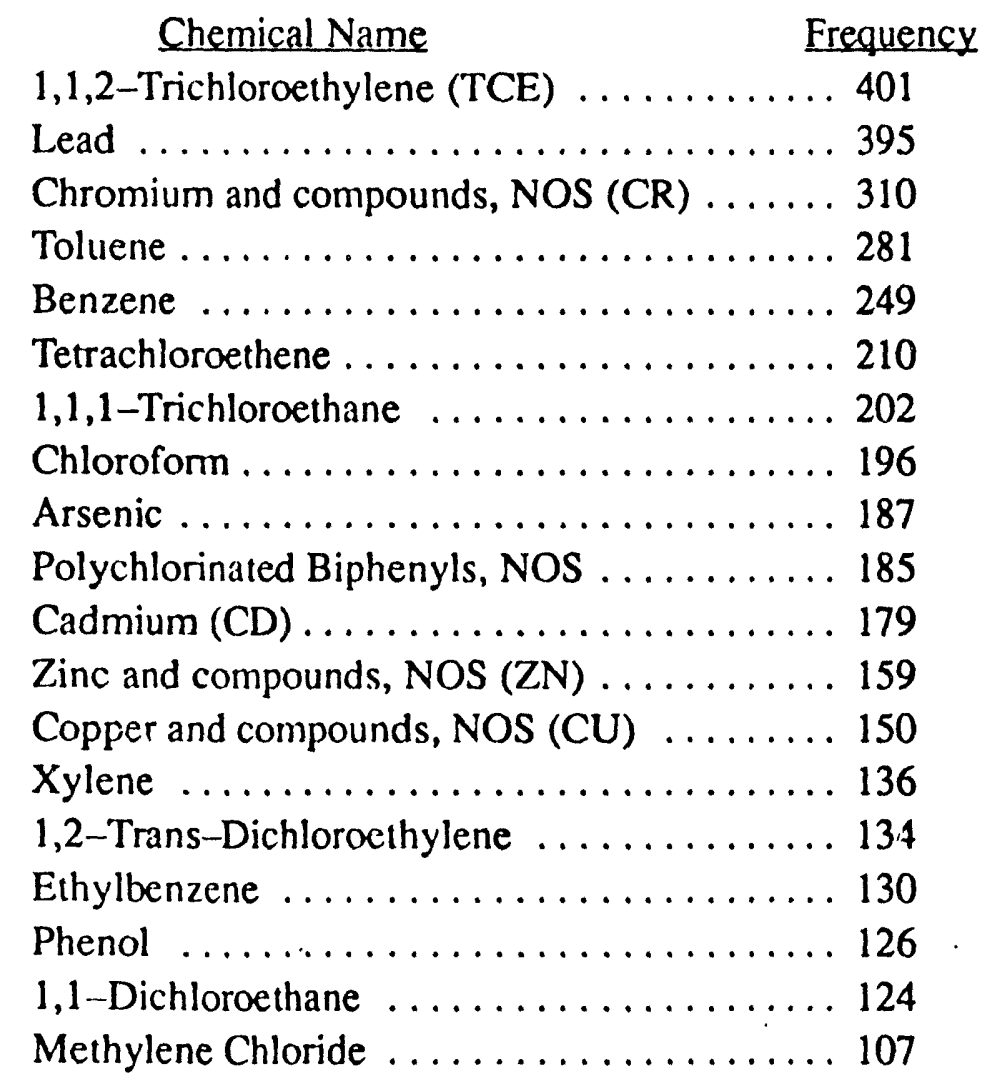


1,1-Dichloroethene ................ 106

Mercury ......................... 97

Vinyl Chloride .................... 92

Cyanides (soluble salts), NOS .......... 90

Nickel and compounds, NOS (NI) . . . . . . . 83

Carbon Tetrachloride $\ldots \ldots \ldots \ldots \ldots \ldots \ldots 81$

1,2-Dichloroethane ................. 77

Chlorobenzene $\ldots \ldots \ldots \ldots \ldots \ldots \ldots \ldots, 65$ 


\section{DISTRIBUTION}

\section{U.S. Department of Energy}

Gylan Allen

Test Operations Division

Nevada Operations Office

U.S. Department of Energy

P.O. Box 98518

Las Vegas, NV 89193-8518

\section{Doug Duncan}

Hydrology Program Manager

Office of Environmental Restoration

and Waste Management

Nevada Operations Office

U.S. Department of Energy

P.O. Box 98518

Las Vegas, NV 89193-8518

Donald Elle, Director

Environmental Protection Division

Nevada Operations Office

U.S. Department of Energy

P.O. Box 98518

Las Vegas, NV 89193-8518

Joseph N. Fiore, Acting Assistant Manager Office of Environmental Restoration and Waste Management Nevada Operations Office

U.S. Department of Energy

P.O. Box 98518

Las Vegas, NV 89193-8518

Joseph H. Kitchen

Technology Development and

Program Management Division

Nevada Operations Office

U.S. Department of Energy

P.O. Box 98518

Las Vegas, NV 89193-8518
Steve Lawrence

Environmental Restoration Division

Nevada Operations Office

U.S. Department of Energy

P.O. Box 98518

Las Vegas, NV 89193-8518

John S. Ledbetter

Contracts Division

Nevada Operations Office

U.S. Department of Energy

P.O. Box 98518 , MS 505

Las Vegas, NV 89193-8518

Steve Leedom

Test Operations Division

Nevada Operations Office

U.S. Department of Energy

P.O. Box 98518

Las Vegas, NV 89193-8518

Catherine McWilliam

Office of Environmental Restoration

and Waste Management

Nevada Operations Üfifice

U.S. Department of Energy

P.O. Box 98518

Las Vegas, NV 89193.8518

Steve Mellington, Director

Environmental Restoration Division

Nevada Operations Office

U.S. Department of Energy

P.O. Box 98518

Las Vegas, NV 89193-8518

Technical Information Resource Center

Nevada Operations Office

U.S. Department of Energy

P.O. Box 98518

Las Vegas, NV 89193-8518

Richard Pearl

Environmental Protection Division

Nevada Operations Office

U.S. Department of Energy

P.O. Box 98518

Las Vegas, NV 89193-8518 
Caroline Purdy

U.S. Department of Energy

EM-542

12850 Middlebrook Road

Trevion II

Germantown, MD 20874

\section{U.S. Department of Defense}

David Bedsun

Defense Nuclear Agency

U.S. Department of Defense

P.O. Box 98539

Las Vegas, NV 89193-8539

\section{Lawrence Livermore National Laboratory}

Lee Davisson

Nuclear Chemistry Division

Lawrence Livermore National Laboratory

P.O. Box 808

L-237

Livermore, CA 94550

Greg Nimz

Lawrence Livermore National Laboratory

P.O. Box 808

MS L233

Livermore, CA 94550

\section{Los Alamos National Laboratory}

Joe Thompson

Los Alamos National Laboratory

INC-11, MS J514

P.O. Box 1663

Los Alamos, NM 87545

\section{U.S. Geological Survey}

Virginia Glanzman

U.S. Geolopical Survey

Box 2506, MS 913

Denver Federal Center

Denver, CO 80225
Randy Laczniak

U.S. Geological Survey

Water Resources Division

6770 S. Paradise Rd.

Las Vegas, NV 89119

Paul Orkild

U.S. Geological Survey

Box 2506, MS 913

Denver Federal Center

Denver, CO 80225

Doug Trudeau

U.S. Geological Survey

Water Resources Division

6770 S. Paradise Rd.

Las Vegas, NV 89119

\section{Desert Research Institute}

Roger Jacobson

Desert Research Institute

Water Resources Center

P.O. Box 19040

Las Vegas, NV 89132-0040

Marjory Jones

Desert Research Institute

Water Resources Center

P.O. Box 60220

Reno, NV 89506-0220

Paul Seaber

Desert Research Institute

Water Resources Center

P.O. Box 19040

Las Vegas, NV 89132-0040

Reynolds Electrical \& Engineering Co.

Martha DeMarre

Chief, Document Research Section

Health Protection Dept.

Reynolds Electrical \& Engineering Co.

P.O. Box 98521

Las Vegas, NV 89193-8521

Brian Dozier

Reynolds Electrical \& Engineering Co.

2501 Wyandotte

Mercury, NV 89102 


\section{LIBRARIES}

\section{Archives}

Getchell Library

University of Nevada, Reno

\section{Beverly Carter}

MacKay School of Mines Library

University of Nevada, Reno

Stead Library

Desert Research Institute

Reno, Nevada

Southern Nevada Science Center

Water Resources Center, Library

P.O. Box 19040

Las Vegas, NV 89132-0040

Document Section, Library

University of Nevada, Las Vegas

4505 Maryland Parkway

Las Vegas, NV 89154

Annie Kelley

State Documents Department

Nevada State Library

Capitol Complex

Carson City, NV 89710

Water Resources Research Archives

University of Califormia

Room 40, North Gate Hall

Berkeley, CA 94720

\section{BDM Federal}

Bryan J. Albers

BDM Federal

12850 Middlebrook Road

Trevion I, Suite 300

Germantown, MD 20874

David $\therefore$ Roelant

BDM Federal

12850 Middlebrook Road

Trevion I, Suite 300

Germantown, MD 20874

International Technology Corp.

Rick Waddell

Geotrans

c/o IT

4330 Valley View

Suite 112

MS-439

Las Vegas, NV 89103

Joe Yeasted

International Technology Corp.

Southern Nevada Science Center

P.O. Box 19040

Las Vegas, NV 89132-0040 

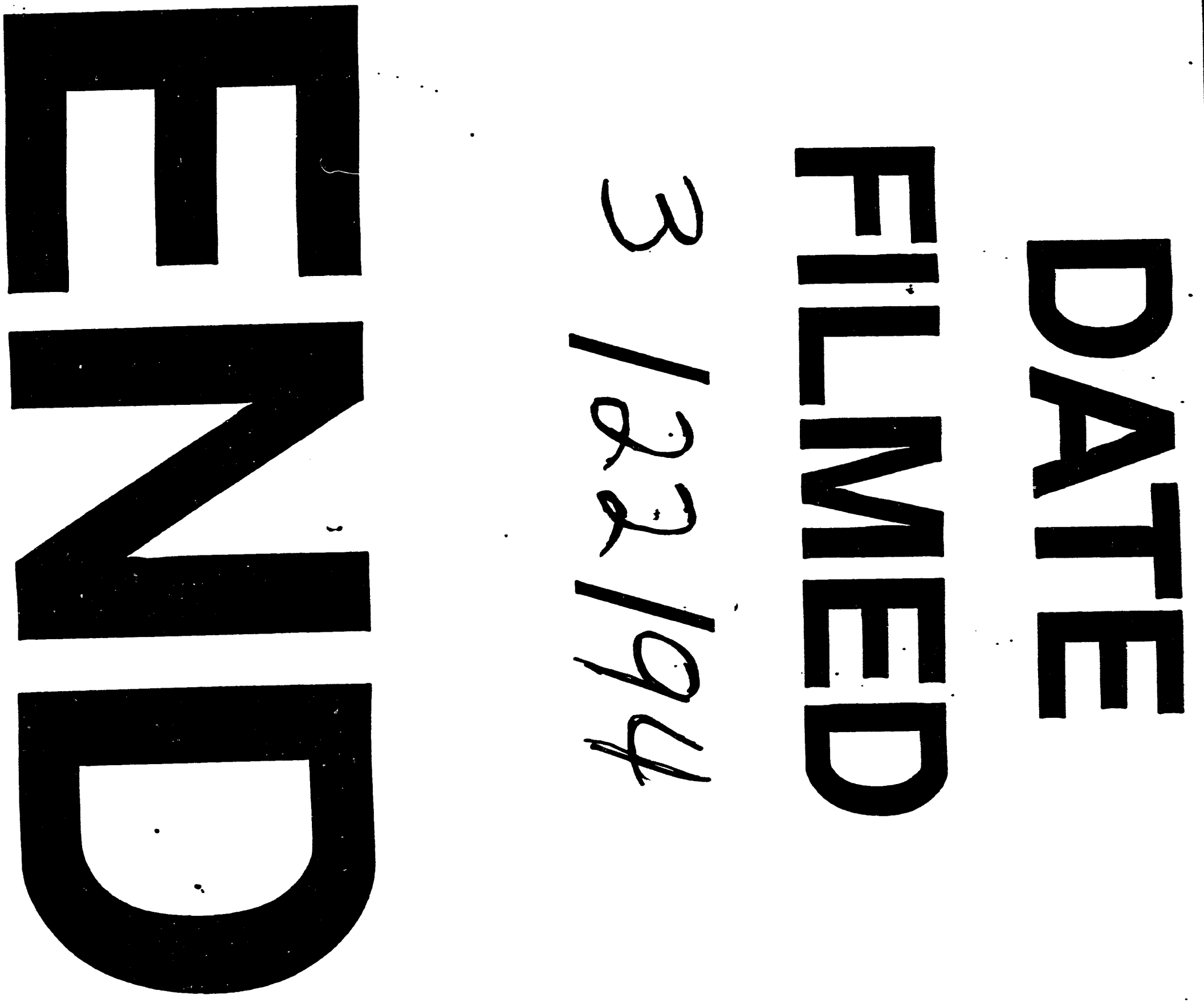


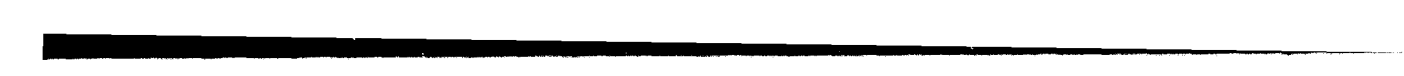

